\title{
IDENTIFICATION OF AGRICULTURAL LAND USE IN CALIFORNIA THROUGH
} REMOTE SENSING

\author{
A Thesis \\ presented to \\ the Faculty of California Polytechnic State University, \\ San Luis Obispo
}

\begin{abstract}
In Partial Fulfillment
of the Requirements for the Degree

Master of Science in Engineering
\end{abstract}

by

Todd Allen Robinson

September 2016 
(C) 2016

Todd Allen Robinson

ALL RIGHTS RESERVED 


\section{COMMITTEE MEMBERSHIP}

TITLE: Identification of Agricultural Land Use in California Through Remote Sensing

AUTHOR: Todd Allen Robinson

DATE SUBMITTED: September 2016

COMMITTEE CHAIR: Daniel J. Howes, Ph.D., P.E.

Associate Professor of BioResource and Agricultural Engineering

COMMITTEE MEMBER: Franklin Gaudi, Ed.D.

Lecturer of BioResource and Agricultural Engineering

COMMITTEE MEMBER: Rebekah Oulton, Ph.D., P.E. Assistant Professor of Civil and

Environmental Engineering 


\begin{abstract}
Identification of Agricultural Land Use in California Through Remote Sensing
\end{abstract}

Todd Allen Robinson

Ground truthing actual crop types in an area can be expensive and timeconsuming. The California Department of Water Resources attempts to ground truth land use in each county in California every five years. However, this is limited by budgetary constraints and often results in infrequent (more than every ten years) surveying of many counties. An accurate accounting of crops growing in a region is important for a variety of purposes including farm production estimates, groundwater and surface water modeling, evapotranspiration estimation, water planning, research applications, etc. Agricultural land use is continually changing due to development and environmental factors.

Currently, USDA NASS provides georeferenced land use maps of regions throughout the U.S. While these are beneficial, the accuracy is not very high for California due to the wide variety of crops grown throughout the state. California has an increasingly complex agricultural system which includes multi-crops changing on an annual and even semiannual basis, long growing seasons, and complex and flexible irrigation schedules.

Remotely sensed data from available satellites are used to more accurately classify crop types within the Madera and Merced Counties of California's Central Valley. An initial classification approach utilizing a simplified decision tree for a data subset of the area considered is presented. In order to accommodate the larger dataset at hand, a computer based approach is applied using the Nearest Neighbor classification algorithm in the computer program eCognition. Iterative analyses were performed to consider a range of scenarios with varying spectral inputs. The results show the methods presented can be beneficial in discriminating 24 of the major crop types from multi-temporal spectral data.

Keywords: remote sensing, land classification, decision tree, eCognition, Phenology, object-based classification 


\section{ACKNOWLEDGMENTS}

The author would like to acknowledge financial support for this research provided by California Department of Water Resources (Agreement \# 4600011000). This research could not have been completed without the expertise and guidance of my supervisor, Dr. Daniel Howes. I also would like to thank my wife, Kelly Robinson, for her continual support and encouragement. 


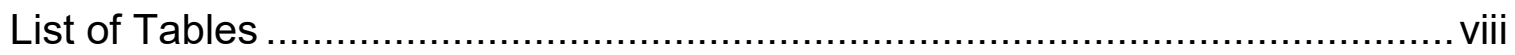

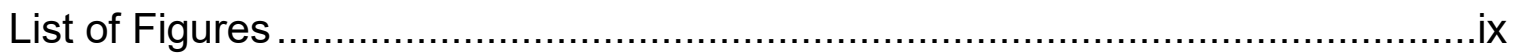

\section{CHAPTER}

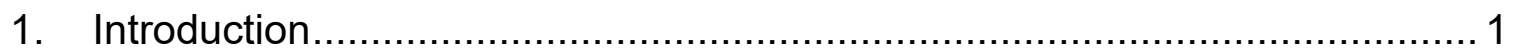

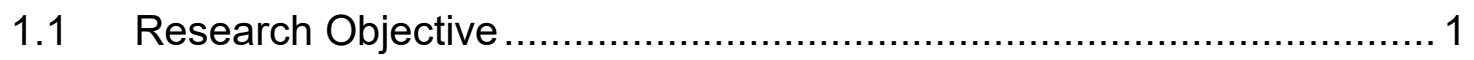

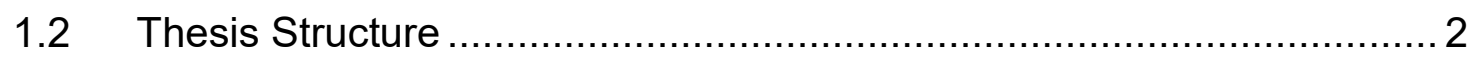

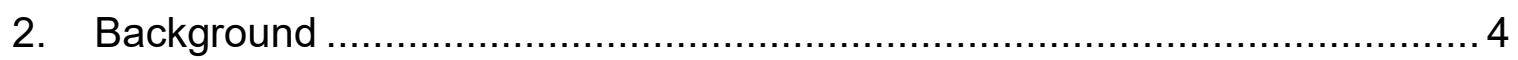

$2.1 \quad$ Importance of Crop Classification …............................................ 4

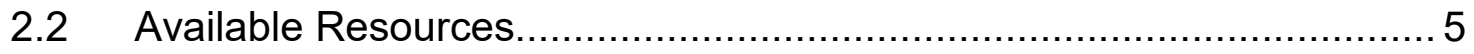

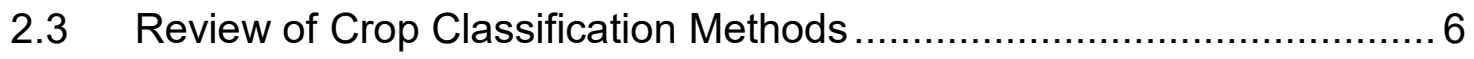

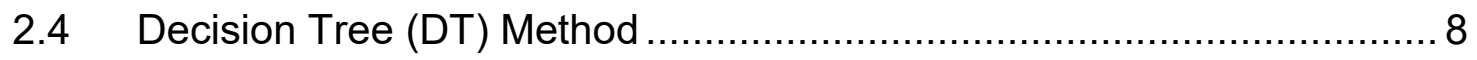

2.5 Phenology-based Approach .................................................... 10

2.6 Computer-assisted Algorithms ....................................................... 12

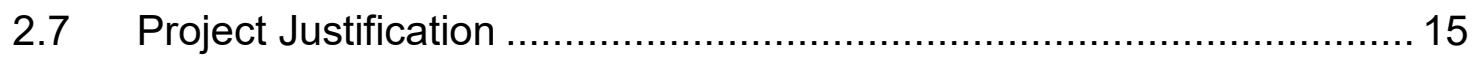

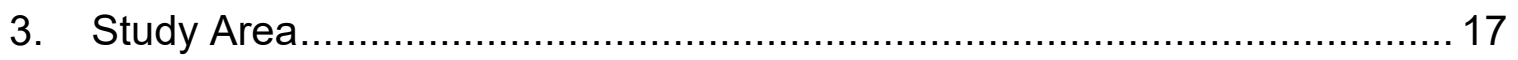

3.1 Madera and Merced Counties ..................................................... 17

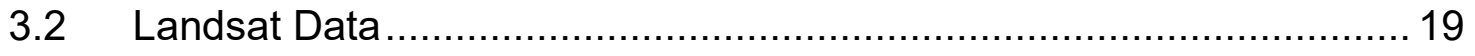

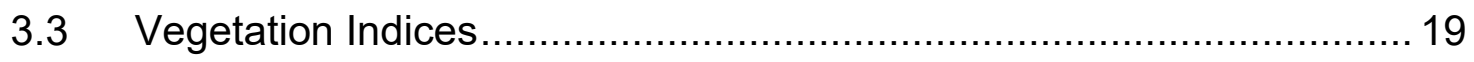

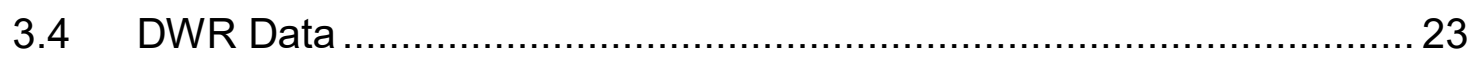

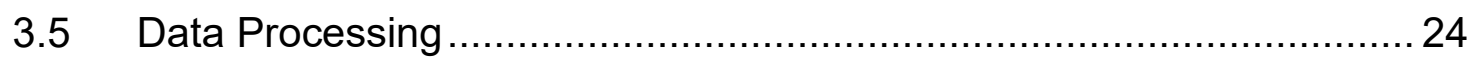

4. Simplified Decision Tree Classification................................................... 26 


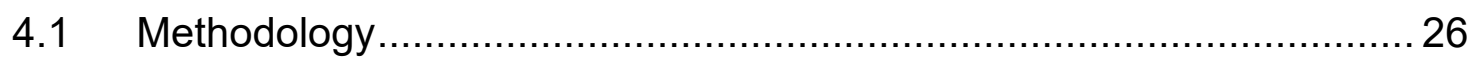

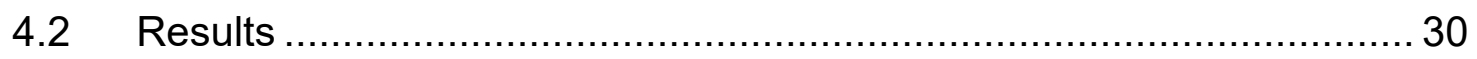

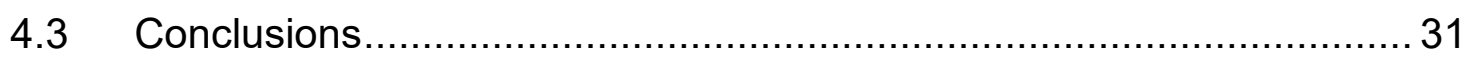

5. Computer-assisted Classification using eCognition.................................. 33

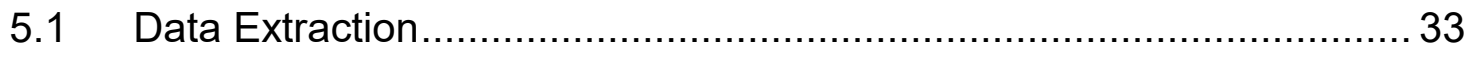

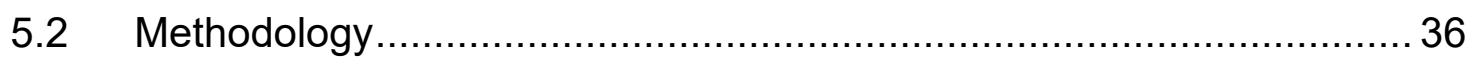

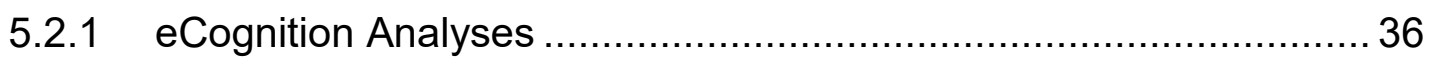

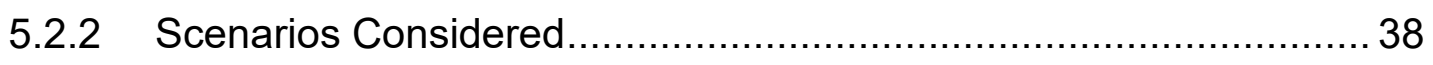

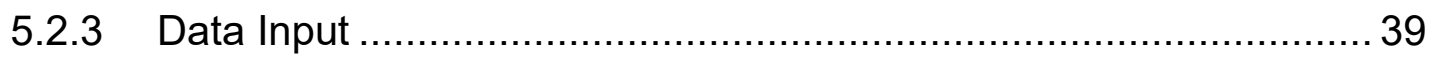

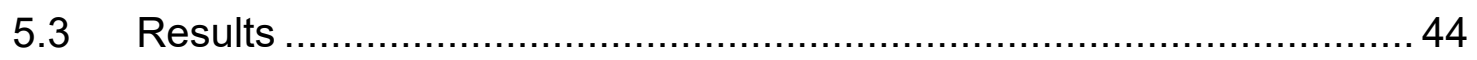

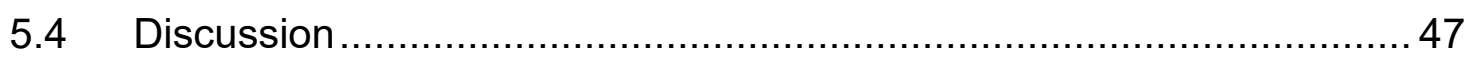

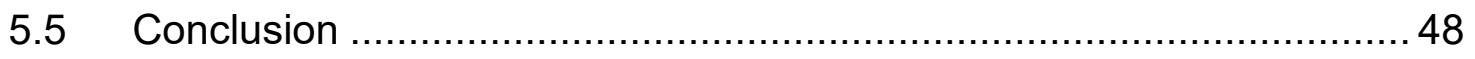

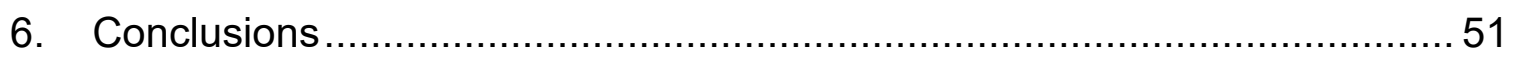

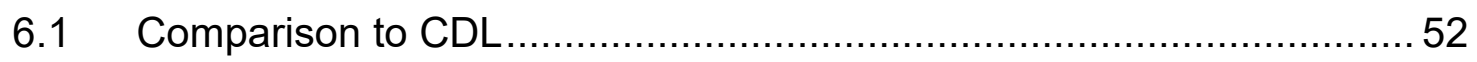

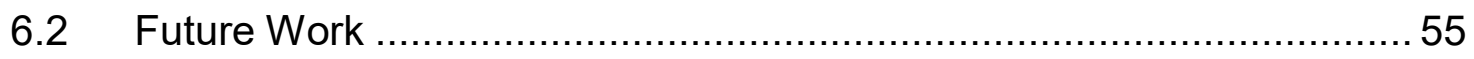

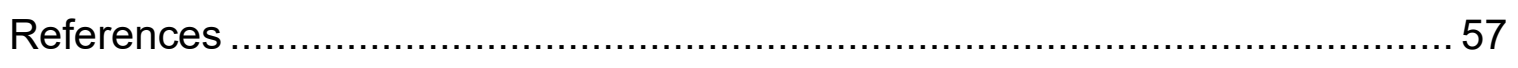

Appendices

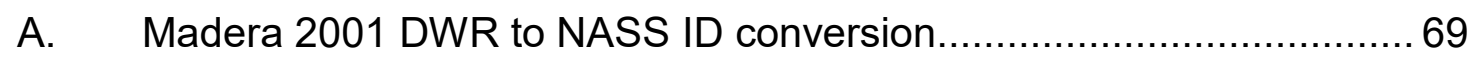

B. Merced 2002 DWR to NASS ID conversion ..................................... 75

C. Full list of NASS ID and Classifier descriptions................................. 82

D. Individual Field Crop Accuracy Results from eCognition Analyses .......84

E. Crop Confusion Matrices Resulting from eCognition Analyses ............90 


\section{LIST OF TABLES}

Table

Page

Table $3-1 . L a n d s a t$ band identification .............................................. 19

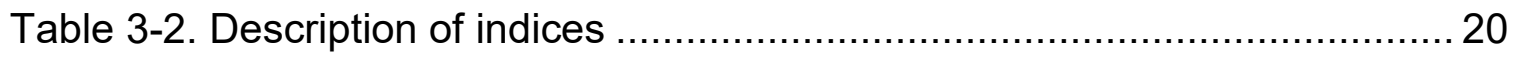

Table 3-3. Typical NDVI values for various cover types (Holben 1986)............ 22

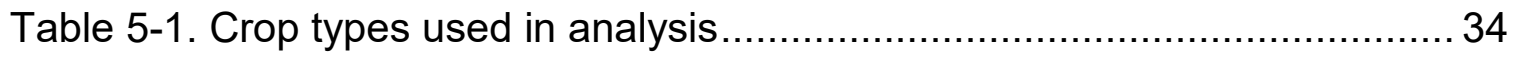

Table 5-2. Field count ground surveyed by DWR ................................ 34

Table 5-3. Percent of total crops analyzed for 2001 Madera, 2002 Merced, and

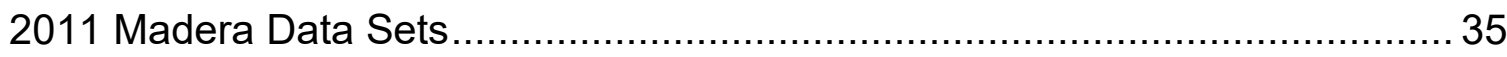

Table 5-4. Satellite dates used for multi-temporal analysis ........................ 40

Table 5-5. Summary of results from eCognition analyses .......................... 45

Table 6-1. Accuracy comparison of 2011 Madera CDL versus 2011 Madera

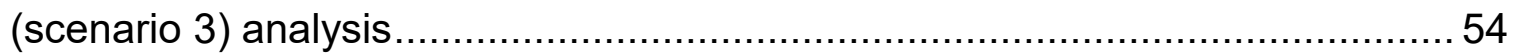




\section{LIST OF FIGURES}

Figure

Page

Figure 2-1. Sample NDVI temporal series showing fitted double-sigmoid curve

Figure 3-1. Location of Merced and Madera County datasets 18

Figure 4-1. Schematic DT diagram ....................................................... 27

Figure 4-2. Average albedo and reflectance band 5 values for selected crops on $8 / 25 / 2002$ (vertical error bars represent $+/-2$ б)

Figure 4-3. Average LAl and net radiation values for selected crop subsets on 6/6/2002 (vertical error bars represent $+/-2$ б) 29

Figure 4-4. Merced 2002 Decision Tree Schematic 31

Figure 5-1. eCognition Process Tree Sample............................................. 37

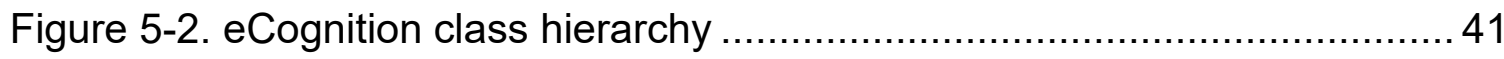

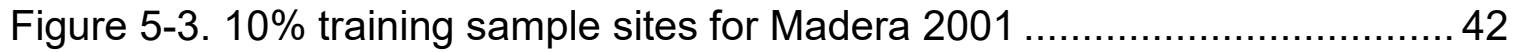

Figure 5-4. Sample editor comparing class feature space created for Cotton (black) and Alfalfa (blue)

Figure 5-5. Example of final classification results using the $\mathrm{NN}$ algorithm in eCognition 


\section{INTRODUCTION}

The following presents the objective of this research and a brief summary of the general layout of the thesis.

\section{$1.1 \quad$ Research Objective}

The purpose of this research is to develop a simple and repeatable crop classification methodology that can be used in the Central Valley of California. While cataloging California's crop inventory for policy and environmental necessity is important; there is a clear need for the proposed methodology to be relatively inexpensive and minimize future work during implementation.

It has been shown that object-based analysis has advantages over pixel-based analysis as the spatial resolutions increase (Blaschke 2010). In order to improve the accuracy of the classification, various classification methods that include object-based analysis, segmentation, curve fitting (phenology), ancillary spatial data, and Actual Crop Coefficient data were reviewed.

To simplify the analysis, the research concentrated on available data from two Central Valley counties, Merced and Madera. The base data utilized included available publicly disseminated satellite imagery and Actual Crop Coefficient data acquired through the Irrigation Training Research Center (ITRC) at California Polytechnic State University San Luis Obispo (Cal Poly). This research focused 
on the applicability of two separate approaches to classify land crop types for the subject areas including:

1) a simplistic manual hybrid decisions tree capable of classifying crop types based on user thresholds; and

2) a computer-assisted algorithm using the object-based image analysis software Trimble ${ }^{\circledR}$ eCognition.

\subsection{Thesis Structure}

This thesis has been broken into six chapters for clarity purposes. Chapter 1 provides the research objective and outline of the thesis.

Background information regarding the importance of land classification, various datasets and typical classification methods used in current practice are summarized in Chapter 2.

Chapter 3 introduces the study area of this research as well as the collated data available in the area of focus. Data processing was then performed in order to achieve a simplified dataset for analyses.

Chapter 4 demonstrates the use of a simplified decision tree classification system in land crop classification for a subset of data from one of the subject areas. The results are summarized with respect to strengths and shortcomings of this 
classification method and the ultimate need for further classification techniques such as computer-assisted algorithms.

As described in Chapter 5, the object-based image analysis software Trimble ${ }^{\circledR}$ eCognition was used to develop a crop classification system for the relative datasets used for this research. A description of the methodology employed and findings are provided.

Lastly, Chapter 6 includes a summary of the research performed for this study. Findings are highlighted with respect to the contribution of this research, limitations of the methods employed, and future work. 


\section{BACKGROUND}

This chapter serves to provide the reader with background information regarding crop classification and remote sensing techniques, as well as introduce terminology to be used throughout the thesis. Upon review of methods used in current practice, there is a clear need for an improved classification system, particularly with respect to the complex agriculture in the Central Valley, California.

\subsection{Importance of Crop Classification}

Due to its long growing seasons and economic strength, California has one of the most productive and varied agricultural industries in the world. As a result, agricultural awareness and land use classification is becoming ever more important. Population increase strains food demand on all scales making crop assessment and yield calculation critical in order to effectively maintain a balance between the two (Toan et al. 1997, Doraiswamy et al. 2004). Continually changing climatic conditions provide periods of limited water supplies and further emphasize the importance of accurate assessments of consumptive crop water use, making the necessity for accurate land use classification a key component for on-farm decision-making, economical assessment, land use change monitoring (Vogelmann et al. 1998), and policy development (Zilberman et al. 1994).

Although the California Central Valley is a highly dynamic and productive agricultural region, the semi-arid/arid environment generally results in water scarcity during summer months as well as long periods of low precipitation during 
winter months, making irrigation scheduling difficult (Dinar and Zilberman 1991). Accurate annual crop classification can help in understanding agricultural consumptive requirements which are a key parameter in water balance equations. Prudent decision making on farm and district levels require water balance analysis for conservation and water management (Burt 1999).

\subsection{Available Resources}

Since the late 1940's the California Department of Water Resources (DWR) has continually surveyed and monitored land use changes (Wall et al. 1984). DWR attempts to ground truth land use in each county in California every five years through ground surveying. However, due to budget constraints, some counties are only examined once every ten years at best. The disseminated land use information is publically available for download from DWR as parcel shape files for select counties. This data can be used as ground truthing to verify known data points and also as "training data" when developing alternative supervised classification methods.

The U.S. Department of Agricultural (USDA), National Agricultural Statistics Service (NASS) provides crop land classification via a web-based application called CropScape. CropScape is a user-friendly platform capable of customizing, downloading, analyzing and broadcasting geospatial data for agricultural applications (Han et al. 2012). The program has expanded over the years with 
funding from outside sources. USDA NASS also provides georeferenced land use maps at 30- to 56-meter resolution throughout the U.S.

Since the CropScape program's beginning in 1997, Cropland Data Layer (CDL) datasets have been processed by NASS field offices and analyzed by the Spatial Analysis Research Section (SARS), a subset of NASS. The CDL dataset primarily utilizes satellite imagery to provide acreage estimates for the Agricultural Statistics Board (ASB). ASB uses a supervised classification of the cropland cover with training sample points from the Farm Service Agency (FSA) and National Land Cover Data (NLCD) for the See5 decision tree (DT) classifier. Users can download georeferenced tiff images directly. Shortcomings of the dataset include the exclusion of double crops or areas that include more than one crop type, which can limit the accuracy of the data in agricultural areas where crop rotation is common (Boryan and Craig 2005).

\subsection{Review of Crop Classification Methods}

With the increase in common computing power, accessing and processing agrogeoinformation is not only viable but also extensively used. The past several decades have presented extensive literature discussing land cover classification products and procedures. Some examples include discrimination of forest types (Vieira et al. 2003), crop field types (Price et al. 1997, Kandrika and Roy 2008, Yan and Roy 2014), and land cover characterization on a global scale (Townshend et al. 1991, Running et al. 1995, De Fries et al. 1998, Vogelmann et al. 1998, Hansen 
and Loveland 2012). Further, research has been performed utilizing multi-spectral satellite data to increase accuracy in urban land use classification through the use of vegetative indices (Yuan and Bauer 2007) and impervious identification to map urban spread (Ridd 1995, Lu and Weng 2006). Remote sensing has been utilized extensively for classification of crop types in California but it has been proven to be difficult as season lengths in California often exceed 280 days (Wall et al. 1984) allowing for multiple crop rotations and varied irrigation methodologies.

Review of global and regional land cover methods reveals the importance of consistency and reliability of sensors (Townshend et al. 1991). The recent increase in sensor resolution and availability of various spectral bands has presented an opportunity for the remote sensing community to develop a plethora of models and approaches to land cover classification. A broad range of methods and approaches have been reviewed and range anywhere from utilization of human expertise and traditional methods to newer computer-assisted and algorithm-based predictor models.

Systematic repetitive collection of data from satellites can provide insight from multi-year analysis to determine cropping patters (Martínez-Casasnovas et al. 2005). Ample literature available provides insights to the benefits of multi-temporal analysis for crop discrimination (Murakami et al. 2001) (Turker and Arikan 2005) (De Santa Olalla et al. 2003). Analysis based on image object classification rather 
than a pixel-based level, can contribute to higher accuracy reducing noise (Tso and Mather 1999).

As land cover mapping and assessment are key elements in remote sensing data analysis and application (Foody 2002), derivation of applicable classification techniques is critical to successful application to land cover discrimination. A detailed review and survey of common land use classification methods and techniques developed is provided by Lu and Weng (2007) and Nath et al. (2014). Otukei and Blaschke (2010) identified that methods for classification can be divided into common or advanced schemes. A few of the more common methodologies applicable to this study are discussed below.

\subsection{Decision Tree (DT) Method}

The Decision Tree (DT) methodology is a relatively simplistic approach which uses a flowchart to narrow down the appropriate crop classification based on thresholds determined from imagery data for a particular crop type. Considered a common scheme, Friedl and Brodley (1997) determined that DT classification outperformed other advanced classification methods when evaluated on three different sets of remote sensing data. Based on initial review, this method appears to be straight forward allowing direct user input. Algorithms created by the decision tree can be easily reviewed and adjusted as needed based on user experience. Hansen et al. (1996) provided insight to pre-processing methods and the use of vegetation indices which give DTs several advantages over other methods, including the 
flexibility for users to define thresholds manually based solely on professional expertise. Other researchers have found similar conclusions (Running et al. (1995), De Fries et al. (1998)).

The DT method can be readily expanded to incorporate more advanced schemes that may increase accuracy. Various algorithms including neural networks and fuzzy classifiers can be incorporated into the decisions trees (Wang 1990, Shimabukuro and Smith 1991, Bischof et al. 1992, De Fries et al. 1998, DeFries and Chan 2000, Huang et al. 2002, Mountrakis et al. 2011). Definition of DT's using more complex computer-assisted algorithms such as s-plus statistical software (Hansen et al. 2000), C5.0 software (Friedl et al. 1999) or regression tree analysis (Michaelsen et al. 1994) have shown acceptable results. Increased accuracy in machine learning algorithms have been seen with the inclusion of methods such as boosting, Bootstrap Aggregation (bagging) or pruning (Pal and Mather 2001). These approaches are techniques added to algorithms the decrease the variability, bias, or improved predictive force of a data set.

Although simplistic and with several advantages, the DT approach does have its limitations. For example, variability in spectral data can make it difficult to determine appropriate user thresholds, particularly as the DT grows and crops become more alike in spectral signatures. In addition, image discrimination is complex and paramount importance is placed on the selection of appropriate ground survey data used to determine the classification thresholds. The common 
DT method may prove to be most beneficial to classify more global classifications such as crop vs. non-crop or trees vs. ground crops classes rather than final crop classification on a micro scale.

\subsection{Phenology-based Approach}

Multi-temporal images can add to the computing complexity of the analysis by attributing to larger data volume. An alternative approach to analyzing these multitemporal datasets incorporates a phenology-based approach, similar to that described by Zhong et al. (2012). Based on physical and physiological data captured by satellite imagery, it is possible to create a phenology-based curve from spectral indexes. For example, Van Dijk et al. (1987) designed a polynomial function to smooth composite VI values and Zhong et al. (2012) and Soudani et al. (2008) present the use of a piecewise logistic function modified using an asymmetric double-sigmoid function for determining phenology thresholds.

An alternative classification approach involves the use of logistic functions (e.g. (Zhang et al. 2003, Soudani et al. 2008)). Similar to Zhong et al. (2012) and Shimabukuro and Smith (1991), curve-fitting has been used to detect phenological stages through the use of double sigmoid functions. For example, Zhong et al. (2012) developed the asymmetric double sigmoid function provided in equation $(2-1)$ to fit a curve to the vegetation index, Normalized Difference Vegetation Index (NDVI). 


$$
V(t)=V_{b}+\frac{1}{2} V_{a}\left[\tanh \left(p\left(t-D_{i}\right)\right)-\tanh \left(p\left(t-D_{d}\right)\right)\right]
$$

Where: $\quad V(t)=$ NDVI at time $t$

$t=$ Day of Year (DOY)

$V_{b}=$ base NDVI value related to the non-leaf season

$V_{a}=$ amplitude of NDVI within the growing season

$D_{i}=$ DOY with the highest increasing rates of NDVI

$D_{d}=$ DOY with the highest decreasing rates of NDVI

$p=$ increasing rate change

$q=$ decreasing rate change

The double asymmetric sigmoid function can be fit to the data points utilizing the solver function in excel by changing the variables on the right hand side of equation to better fit the curve. Figure 2-1 illustrates a typical phonological cycle expected for a single crop, considering the NDVI parameter. Creating a metric using the curve-fitting method can reduce computational complexity in crop classification (Zhong et al. 2012) and ultimately user cost.

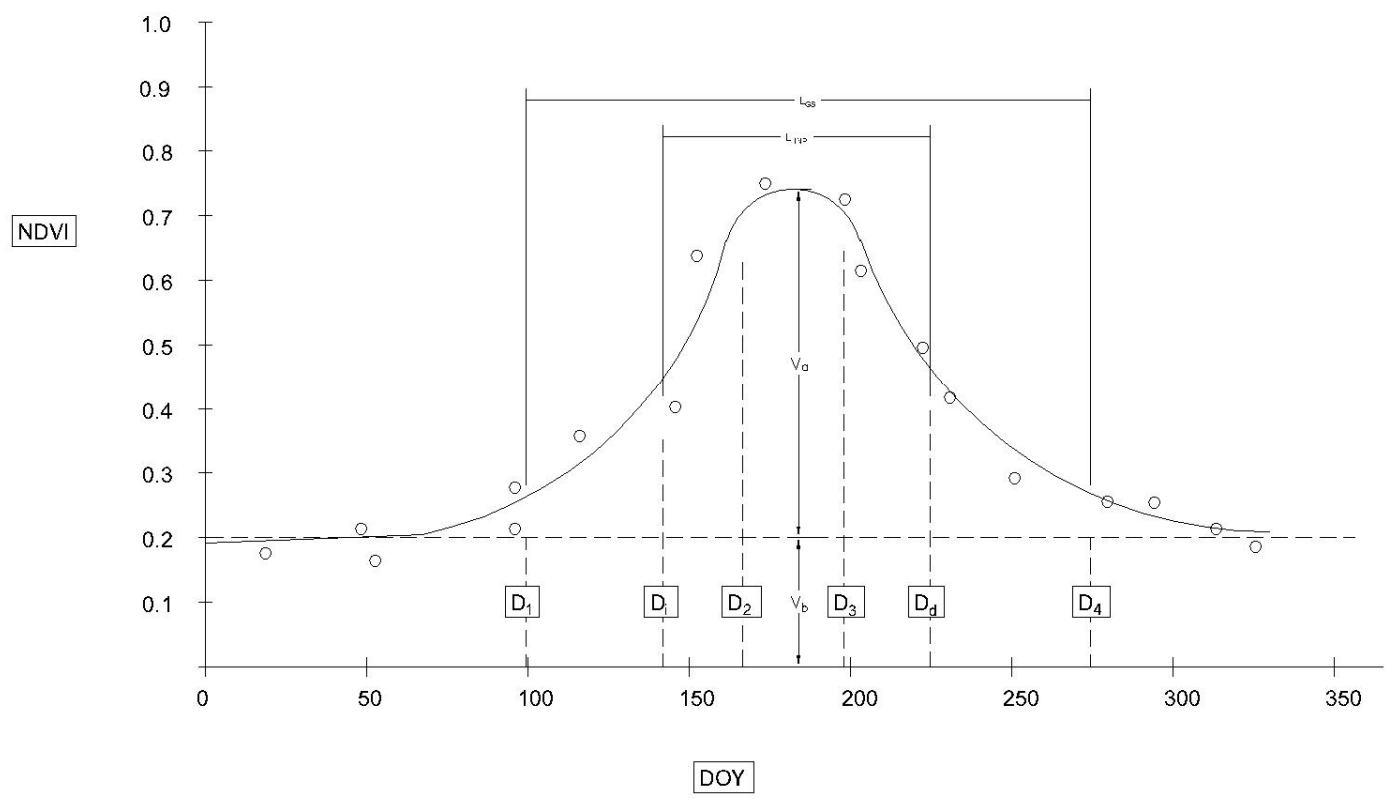

Figure 2-1. Sample NDVI temporal series showing fitted double-sigmoid curve 
A phenology-based approach may be a successful classification scheme for crops with discernable cropping calendars. It is anticipated that this method would likely perform better on classifying single crops with consistent, well defined spectral patters (e.g. NDVI), as shown in Figure 2-1. However, the method requires the user to have an understanding of local cropping practices. Furthermore, this method relies on user expertise as threshold levels may require continual adjustment based on changes in agricultural practices or climatic conditions within regions or time under consideration (year of data collection). The Central Valley's immense variety of crop types and multiple crop rotations would prove the phenology-based approach to be computationally difficult and was not considered in this analysis.

\subsection{Computer-assisted Algorithms}

This approach utilizes a computer to run more complex classification algorithms. The benefit of a computer-assisted algorithm is its ability to handle large data sets and efficiently reduce computation time compared to manual approaches. The more common algorithms are reviewed in this section.

The Maximum Likelihood Classification (MLC) utilizes a supervised or unsupervised classification approach, i.e. with or without training data, as described by Otukei and Blaschke (2010). Computer based algorithms have been applied to include other methodologies such as: decisions trees e.g. Quinlan (1993); support vector machines (SVMs); e.g. Melgani and Bruzzone (2004) and 
Mountrakis et al. (2011); neural networks, e.g. Gopal and Woodcock (1996); and least-squares mixing, e.g. Shimabukuro and Smith (1991), to name a few. Improved spatial and spectral resolution has made the algorithm training processes and classification approach more complex. Additional Improvement of sensor resolution has increased the data size which requires more computing power.

A computer program that is widely used in the remote sensing community, eCognition, has been shown to be a powerful tool with many applications for classification and change detection using remote sensing applications. Recent advances in object-based analysis and complex computer algorithms can be incorporated into eCognition through image segmentation, feature space and data extraction applied to built-in classification schemes. Previous work by Stumpf and Kerle (2011) in eCognition has shown good results detecting landslides using the Random Forests algorithm. Recursive fuzzy classification logic has been used in eCognition to classify rangeland at $87 \%$ accuracy (Laliberte et al. 2011). Laliberte et al. (2004) mapped shrub encroachments in southern New Mexico using the Nearest Neighbor (NN) algorithm in eCognition to accuracies of about $87 \%$.

The NN algorithm relates how close an object is to the defined feature space and ultimately assigns values of 1.0 if the object is an exact match or if an object is not related to the feature set it is assigned a value of 0.0 and remains unclassified. For objects that fall in between 1.0 and 0.0 in the feature space, fuzzy logic is 
applied to find the nearest distance to a feature space. For example, eCognition computes a distance (d), standardized by the standard deviation, as shown equation 2-2 below (Geospatial 2016):

$$
d=\sqrt{\sum_{f}\left(\frac{V_{f}(s)-V_{f}(o)}{\sigma_{f}}\right)^{2}}
$$

Where: $\quad V_{f}(s)=$ the feature value of sample object for feature $f$, $V_{f}(o)=$ feature value of image object for feature $f$, and $f=$ the standard deviation

An exponential membership function $z(d)$ is calculated. The membership value $k$ determines the change in $z(d)$ and can be changed by the user. Based on sensitive analysis performed, the value of $k$ used was 0.1 and can range from 0 to 1 :

$$
z(d)=c^{-k d^{2}}
$$

$k$ can be defined further by:

$$
k=\ln \left(\frac{1}{\text { functionslope }}\right)
$$

Once the NN features are defined for the subject classes it can be applied to a classification algorithm. This approach was applied to the analysis for this study, as discussed in Chapter 5.

As discussed above the computer-assisted algorithm approach has many benefits, including decreased computation time, ability to handle higher imagery resolution 
and larger data sets. Some statistical software programs provide a "black box" computational method, which doesn't allow users to review the end classification algorithm and therefore makes it difficult for calibration or trouble shooting. In order to be successful, it is critical that the user maintains full understanding of the algorithms utilized in the analysis and the effects of each variable considered in the process.

\subsection{Project Justification}

While numerous approaches have been developed for crop classification, there still exists a need for a rapid, inexpensive crop classification system. In particular, the complexity of Central Valley, California, agriculture presents challenges and shortcomings for current classification methods. Parcel size, repeatability, labor costs and computing time all are contributing factors. The limitations of available methodologies combined with the complex agriculture of the area has resulted in a quest for a new, innovative approach to classify crop data.

Little research has been found that utilizes common or advanced classification schemes on complex land types such as those found in the California Central Valley. California's large variety of crops, extended cropping calendars, and unique farming methods all contribute to the difficulty in accurate classification of crop types using remote sensing. The research presented in this paper reviews the applicability of two classification approaches in hopes to understand their individual performance in classifying Central Valley crop types. First, a manual 
approach is reviewed for a subset of crop types that uses a common DT method.

A more complex approach is analyzed using the Nearest Neighbor (NN) classification scheme within Trimble's eCognition computer program. 


\section{STUDY AREA}

This research focused on the Madera and Merced Counties in California in hopes of developing an innovative approach to classify crop data through remote sensing techniques. This chapter provides an introduction to the study area and relevant data sets used for analyses. In order to develop a more simplistic and accurate approach, the data sets were corrected and reduced prior to analysis, as described herein.

\subsection{Madera and Merced Counties}

The research focused on available data from the Madera and Merced Counties of the Central Valley, California. The approximate locations of these counties within the Central Valley are provided in Figure 3-1. The scrutinized data included Landsat and DWR data in Madera County from 2001 and 2011, and in Merced County from 2002. 


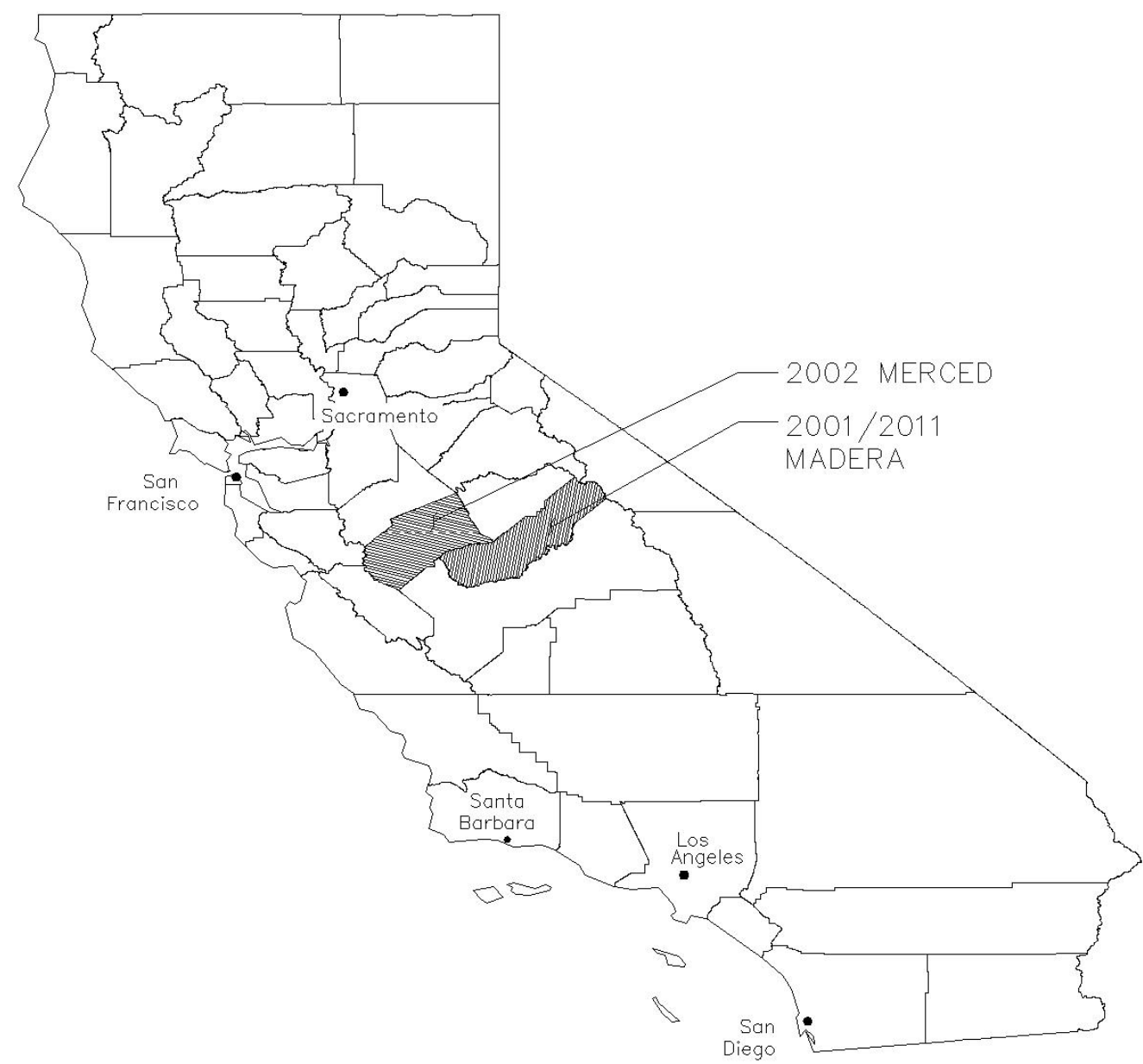

Figure 3-1. Location of Merced and Madera County datasets

The Madera and Merced County data sets were selected for this study because:

- The areas have been ground surveyed by the DWR.

- The Landsat data scenes have been pre-adjusted in-house for atmospheric effects and pre-processed using the ITRC-METRIC.

- Actual evapotranspiration and Actual Crop Coefficients by pixel have been preprocessed by ITRC.

A discussion of the respective data sets used to develop the proposed crop classification methods is provided in the subsequent sections. 


\subsection{Landsat Data}

Two sets of Landsat data were available within the study area: (1) Landsat 5 Thematic Mapper (TM) for path/row 43/34 and (2) Landsat 7 TM for path/row 43/34. Table 3-1 illustrates the band identification and wavelengths available from Landsat 5 - TM and Landsat 7 ETM+ respectively.

Table 3-1.Landsat band identification

\begin{tabular}{|l|l|} 
Band & Description \\
\hline Band 1 & Blue \\
\hline Band 2 & Green \\
\hline Band 3 & Red \\
\hline Band 4 & Near infrared \\
\hline Band 5 & Short-wave infrared \\
\hline Band 6 & Thermal Infrared \\
\hline Band 7 & Short Wave infrared \\
\hline
\end{tabular}

\begin{tabular}{|l|l|l|l|}
\hline \multicolumn{4}{|c|}{ Landsat 7 - Enhanced Thematic Mapper Plus (ETM+) } \\
\hline Band & $\begin{array}{l}\text { Wavelength } \\
\text { (micrometers) }\end{array}$ & $\begin{array}{l}\text { Resolution } \\
\text { (meters) }\end{array}$ & Description \\
\hline Band 1 & $0.45-0.52$ & 30 & Blue \\
\hline Band 2 & $0.52-0.60$ & 30 & Green \\
\hline Band 3 & $0.63-0.69$ & 30 & Red \\
\hline Band 4 & $0.77-0.90$ & 30 & Near infrared \\
\hline Band 5 & $1.55-1.75$ & 30 & Short-wave infrared \\
\hline Band 6 & $10.40-12.50$ & 60 & Thermal Infrared \\
\hline Band 7 & $2.09-2.35$ & 30 & Short Wave infrared \\
\hline Band 8 & $0.52-.90$ & 15 & Panchromatic (Landsat 7 only) \\
\hline
\end{tabular}

\subsection{Vegetation Indices}

As mentioned previously, vegetation indices can be extracted from Landsat data and used for parametric analyses (Tucker 1979). Vegetation indices were developed from spectral bands of available scenes in-house by the ITRC during the subject year. Maximum, minimum, mean and amplitude values were imported 
from the index datasets in raster format. Table 3-2 summarizes the indices considered for this study which included: Albedo, Emissivity, Leaf Area Index (LAl), Normalized Difference Vegetation Index (NDVI), surface temperature adjusted for elevation ( $\left.\mathrm{T}_{\mathrm{s}_{-} \mathrm{dem}}\right)$, humidity $(\mathrm{H})$, Actual Crop Coefficient $(\mathrm{EToF})$, reflectance (bands 1-7), and radiance (bands 1-7). A brief discussion of each of these variables is provided below.

\section{Table 3-2. Description of indices}

\begin{tabular}{|c|c|}
\hline Index & Description \\
\hline Albedo & $\begin{array}{l}\text { Measure of reflectivity (short wave radiation) that is reflected from the earth's } \\
\text { surface }\end{array}$ \\
\hline Emissivity & Measure of the efficiency in which a surface emits thermal energy \\
\hline LAl & (Leaf Area Index) is a dimensionless quantity that characterizes plant canopies \\
\hline NDVI & $\begin{array}{l}\text { (Normalized Difference Vegetation Index) assesses whether the target being } \\
\text { observed contains live green vegetation or not }\end{array}$ \\
\hline NDWI & $\begin{array}{l}\text { (Normalized Difference Water Index) measures the amount of water present in a } \\
\text { leaf internal structure }\end{array}$ \\
\hline$T_{s \text { dem }}$ & Measure of surface temperature accounting elevation \\
\hline $\mathrm{H}$ & $\begin{array}{l}\text { (Sensible Heat Flux ) measures the transfer of heat energy from the Earth's } \\
\text { surface to the atmosphere }\end{array}$ \\
\hline EToF & Actual Crop Coefficient (computed from the ITRC-METRIC) \\
\hline Reflectance & $\begin{array}{l}\text { Fraction of incident radiant flux at a given wavelength reflected by a material } \\
\text { (bands } 1-7 \text { ) }\end{array}$ \\
\hline Radiance & $\begin{array}{l}\text { Flux of radiation emitted per unit solid angle in a given direction by a unit area of } \\
\text { a source (light or heat as emitted of reflected by an object) (bands } 1-7 \text { ) }\end{array}$ \\
\hline
\end{tabular}

Albedo: Albedo is the measurement of the sun's radiation that is reflected back from the surface. Typically, this is expressed as a percentage of wavelength. An example of $0 \%$ albedo would be a black object (e.g. wavelengths are absorbed and not reflected back) versus a true white object would where the albedo value 
could be at $100 \%$. Albedo used in land classification can be useful as the vegetative leafs, plan color, soil color impact this value.

Leaf Area Index (LAI): Leaf area index is a ratio between 0 and 10 that measures the area of leaf per a unit of ground surface.

Normalized Vegetation Index (NDVI): NDVI can indicate the amount of dry biomass above ground through the ratio of visible red (VIS) and near infrared (NIR) channels captured by Landsat spectral imagery (Tucker 1979). A key concept is that this index can sense multiple layers within a crops biomass. For example, the NIR can sense approximately eight leaf layers while the VIS sees only one leaf layer or less (Lillesaeter, 1982).

Chlorophyll on the plant absorbs light in the red channel (0.58-0.68 microns) and foliage reflects light in the near infrared channel (0.72-1.10 microns). The ratio of the reflected light (NIR) less the absorbed light (VIS) to the reflected light plus the absorbed light yields the NDVI, as shown in equation (3-1) below.

$$
N D V I=\frac{N I R-V I S}{N I R+V I S}
$$

The values of NDVI can range between -1.0 and 1.0 (Myneni et al. 1995). The NDVI on farmed land generally increases during leaf development stages and declines after harvest and bare soil generally have larger NIR than VIS values and 
therefore generate small positive NDVI values ranging from about 0 to 0.2 . In contrast, areas covered by vegetation usually correspond to an NDVI of 0.2 or greater. Water areas typically have low NIR and VIS values which result in a very low positive or slightly negative NDVI. Table 3-3 summarizes typical ranges of VIS, NIR and NDVI values for common types of cover (Holben 1986).

Table 3-3. Typical NDVI values for various cover types (Holben 1986)

\begin{tabular}{|l|l|l|l|}
\hline Cover Type & VIS & NIR & NDVI \\
\hline Dense vegetation & 0.1 & 0.5 & 0.7 \\
\hline Bare soil (dry) & 0.69 & 0.283 & 0.025 \\
\hline Clouds & 0.227 & 0.228 & 0.002 \\
\hline Snow and ice & 0.375 & 0.342 & -0.046 \\
\hline Water & 0.022 & 0.013 & -0.257 \\
\hline
\end{tabular}

It is important to understand that the NDVI pixel rarely covers a single homogeneous area of one land cover type. It can encompass many types such as road, vegetation and water all in one. The calculated NDVI is the sum of all the types within the pixel and is considered to look at a general condition more accurately than a crop specific condition.

Normalized water index (NDWI): NDWI is the normalized water index (NDWI) based on the formula originally published by McFeeters (1996) and shown in equation (3-2) below, where $X_{\text {green }}$ and $X_{\text {nir }}$ are the green band (Band 2) and near infrared (nir) band (Band 4), respectively. 


$$
N D W I=\frac{X_{\text {green }}-X_{\text {nir }}}{X_{\text {green }}+X_{\text {nir }}}
$$

Similar to NDVI, the NDWI can range from -1 to +1 and general a positive NDWI values indicate open water surfaces while negative values indicate a non-water surface feature.

Tasseled Cap Transformations: Tasseled Cap Transformations developed by Kauth and Thomas (1976) involve converting a set of readings from the raw data into composite values to indicate brightness greenness and wetness. Crist (1985) used top of atmosphere reflectance bands to calculate Tasseled Cap Transformations including brightness, greenness, wetness, and fourth, fifth and sixth indices, using coefficients presented by Huang et al. (2002) for the Landsat data.

Actual Crop Coefficient, EToF: The Actual Crop Coefficient (ITRC-Metric output), EToF, was developed in-house by the Irrigation Training and Research Center (ITRC). This metric is produced through ITRC modified mapping evapotranspiration at high resolution with internal calibration process.

\subsection{DWR Data}

Land use ground survey data classifying crop types were downloaded from DWR for the Madera and Merced Counties for the respective years of interest (2001, 
2011 Madera and 2002 Merced). DWR descriptors were matched to NASS descriptors for the year of the respective data set in order to identify approximately 80 land cover classifications. The classifications included crop types and non-crop areas, impervious areas and water areas. Refer to Appendix C for a full list of NASS identifications and classification descriptions. Appendices $A$ and $B$ provide a full list of DWR crops and equivalent NASS identifications/descriptors.

\subsection{Data Processing}

Within the DWR data sets, non-crops and unknown crops such as "miscellaneous vegetables and fruits" (NASS ID 47) and "other tree crops" (NASS ID 71) were removed in order to avoid confusion for classification during the study. In addition, crops with less than 10 fields in the county were also removed to avoid classification bias based on a single crop field. Reducing the data to only NASS identifications present within each county and removing non-crops and unknowns, decreased the total classes reviewed for the study and allowed for more accurate analysis. In Madera County approximately 12,350 and 14,700 fields (agriculture and non-agriculture) were defined for the 2001 and 2011 data sets, respectively, and 13,270 fields were defined in the Merced 2002 data set.

The specified vegetation indices as well as a DWR shapefile identifying parcels and crop type were imported into an ArcGIS computer program and re-projected into the Universal Transverse Mercator coordinate system (zone 10) and the WGS 
84 datum. The collective data was then processed in ArcGIS and/or imported into alternative programs as discussed below.

Within ArcGIS, the raster data was extracted for analysis by applying a buffer of 45 meters to each of the parcels/fields. Buffered areas less than 1 acre in size were eliminated. It was discovered that the buffer eliminated noise that may be associated with items such as roads, poor crop uniformity, etc. typically located at the edge of field. Cloud cover was analyzed for both years and it was concluded that the occurrence of clouds in the scenes had a negligible effect in the areas of interest during the time period analyzed. Therefore, no adjustments were made to the data for cloud cover. The processed and reduced data sets were then used in the subsequent analyses presented in Chapters 4 and 5 . 


\section{SIMPLIFIED DECISION TREE CLASSIFICATION}

A simplified decision tree (DT) classification approach was developed using the 2002 Merced data (Landsat and DWR). The following presents a discussion of the methods used to develop the decision tree, findings, and the pros and cons of this type of classification method.

\subsection{Methodology}

As described in Chapter 3, the raster data used for this research was corrected for noise, etc. The data reduction lead to a subset of 11 land type classifications for the 2002 Merced data set. Thus, the DT analysis considered the following land types: asparagus, beans (dry), broccoli, cotton, onions and garlic, peppers, sugar beets, sweet potatoes, table grapes, unknown grapes, and unknown rice.

The objective of the proposed scheme was to produce a model that was simple, observable and repeatable. Previous studies have shown a decision tree (DT) can be an effective tool for crop classification due to its non-parametric nature and ability to effectively handle non-linear relations and non-homogenous inputs (Quinlan 1993). A schematic diagram of the DT process developed for this study is shown in Figure 4-1. 


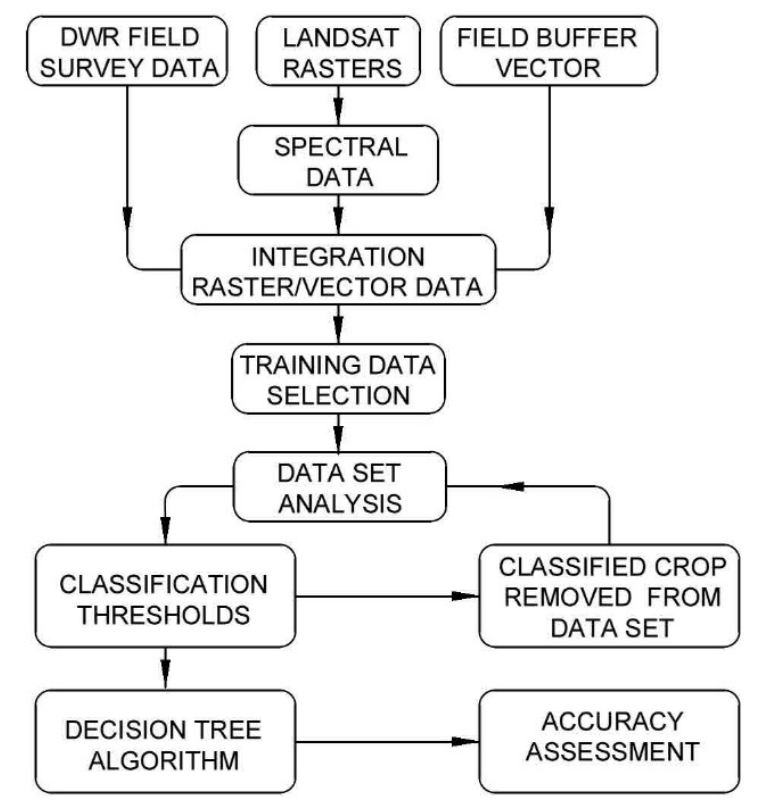

Figure 4-1. Schematic DT diagram

Available spectral data for the subset was scrutinized in hopes of creating a DT model for effectively identifying ground crops. Upon initial review of the data, observable trends were identified for certain crops throughout the year. The observed trends provided relative certainty that the crop type, as identified by DWR, were present in the field during the analysis. Because crop planting and harvest dates varied, the initial DT was created based on multi-temporal spectral data between the dates of March and September 2002.

The first step for land classification involved experience and expertise in identifying temporal trends and vegetation index thresholds for each of the classifications. Initial thresholds for the DT were created using average values from single indices 
for one or more image dates. Once a crop type was classified based on a particular index, it was removed from the subset and the remaining data was re-analyzed.

For example, Figure 4-2 shows average albedo and reflectance 5 values for the various crop types on August 25, 2002. Error bars were used to show +/- two times the standard deviation. Onions and garlic can easily be identified in the figure as the upper bound in both plots. Thus, the use of a threshold value for either albedo or reflectance band 5 can be applied to the data to discriminate this crop type from the remaining subset. Onions and garlic were then removed from the analysis and each of the indices were visually re-scrutinized for further classification.

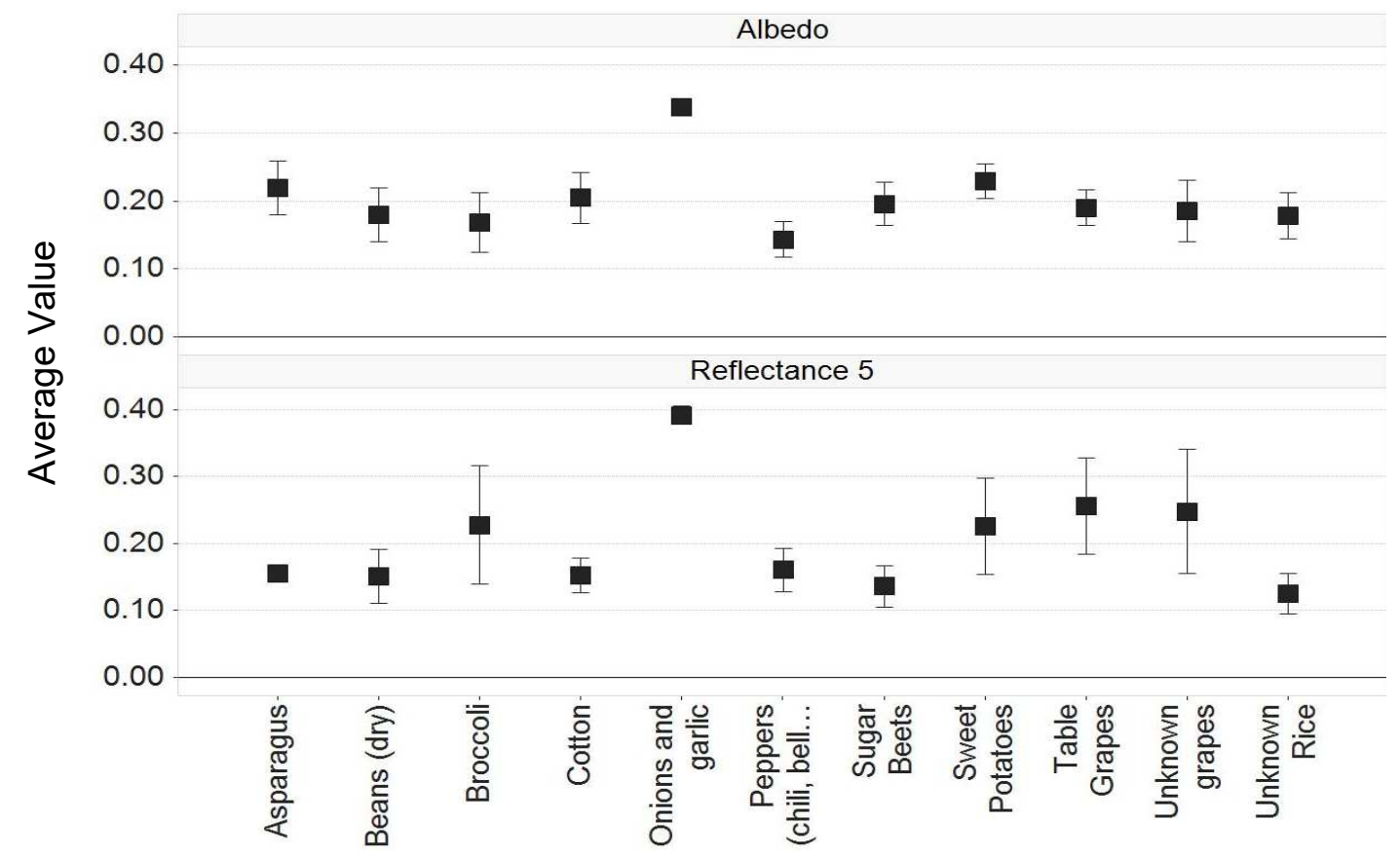

Figure 4-2. Average albedo and reflectance band 5 values for selected crops on 8/25/2002 (vertical error bars represent +/- 2 6) 
After removing onion and garlic crop from the data set, additional thresholds were determined from the average net radiation and LAI parameters which led to the discrimination of asparagus and unknown rice crops. As shown in Figure 4-3, using the ten crop subset (onions and garlic omitted) and considering average LAI and net radiation, respectively asparagus and unknown rice plot distinctively above the remaining data. This approach was applied to 21 indices for each month of the year and resulted in thresholds or discrimination of the data subset.

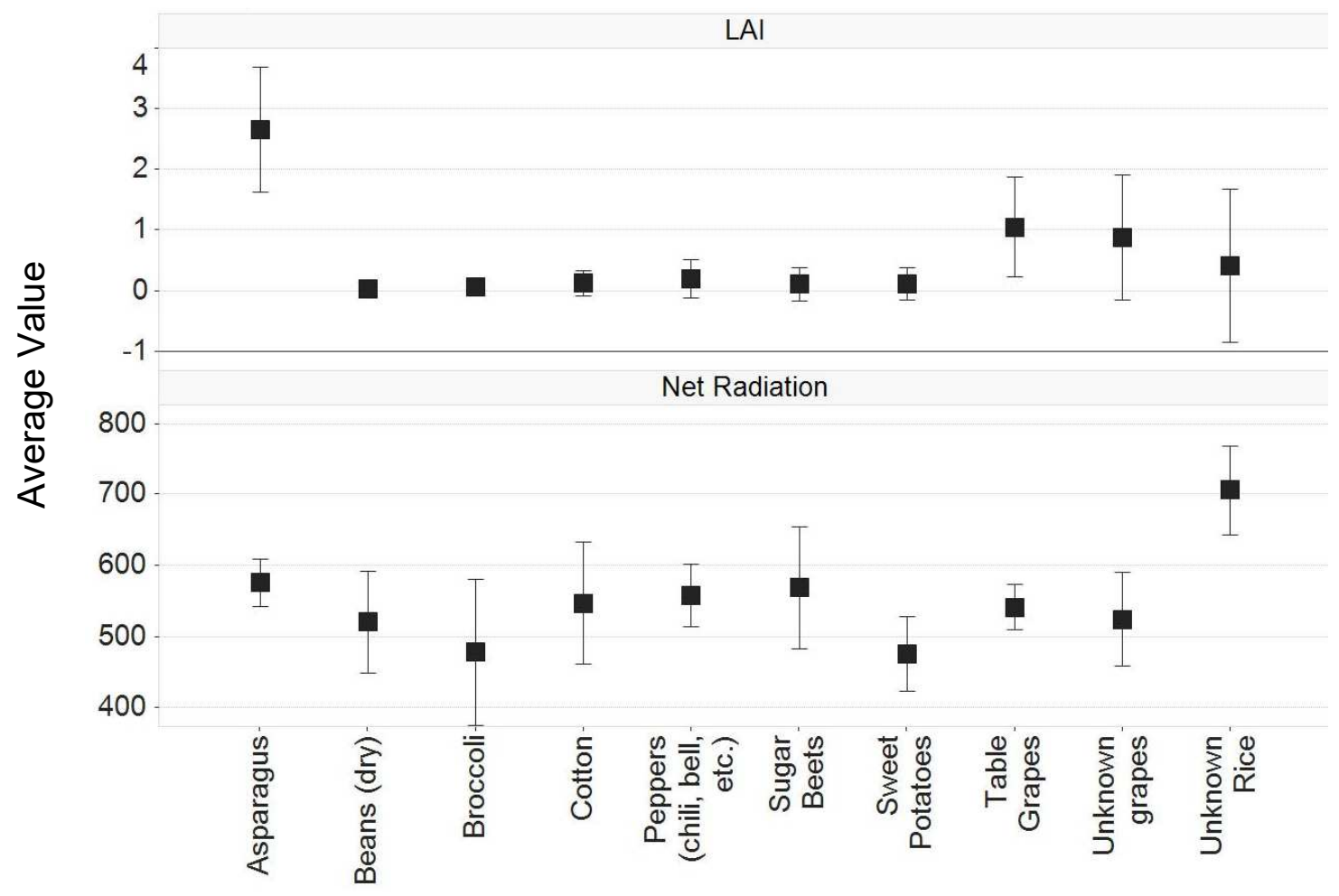

Figure 4-3. Average $L A I$ and net radiation values for selected crop subsets on 6/6/2002 (vertical error bars represent +/- 2 6) 


\subsection{Results}

The results of the analysis led to the simplified decision tree provided in Figure 4-4 for the Merced 2002 data set. As indicated in the decision tree, (9) levels or thresholds were used to help discriminate crop types. At the first level, (1), the use of the albedo spectral index from August 25, 2002 was used to evaluate crop ID's 1 through 11. As described earlier in this section onions and garlic (Crop Type ID $=5)$ were easily discernable from the remaining crop types when comparing Albedo spectral value. The onions and garlic crop was then removed from the data set and the remaining crop types (ID's 1 through 4 and 6 through 11) were reevaluated at the second level. In level (2) the June 22, 2002 LAl spectral index scene was used as a threshold ( $\mathrm{LAI}>1.8$ ) to discriminate asparagus from the other crop types, at which time it was removed from the data set. This approach was continued in a similar fashion through the 9 levels.

Note that in some cases it was necessary to utilize more than one spectral scene to discriminate a crop. For example, in level (5) the LAI and Net Radiance were used to identify broccoli (Crop Type ID =5) within the data set. It was observed that as the decision tree grew the spectral signatures became more similar which made them more difficult to classify. Some spectral overlap was then required to determine the appropriate thresholds. 


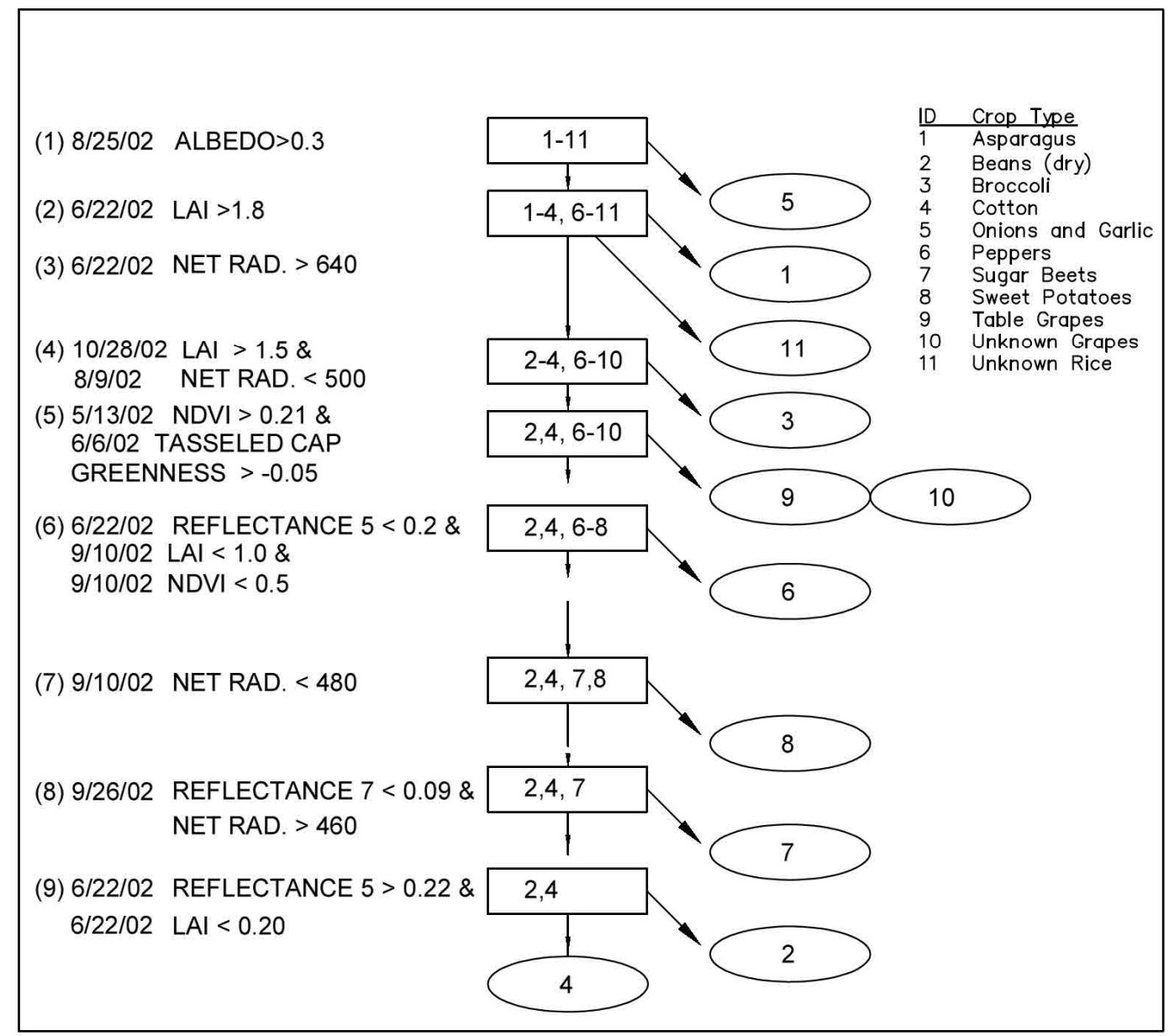

Figure 4-4. Merced 2002 Decision Tree Schematic

\subsection{Conclusions}

A supervised hybrid DT was created using the initial 2002 Merced data subset to discriminate 11 crops types from multi-temporal spectral data. Discrimination of crops grew more difficult further down the decision tree as spectral overlap increased.

The decision tree was shown to be successful in classifying the select subset (11 crops) through discrimination of various indices. However, when attempting to 
apply the method to a larger dataset, several shortcomings were encountered due to the complexity and volume of the data. The accuracy of the decision tree significantly decreased when other crops outside the 11 crop subset are introduced into the analysis. This may be due to the quality of the training data and therefore could be improved in the future. In addition, crops with more variable spectral signatures, i.e. evergreens, alfalfa, or fields with crop rotation, led to misclassification within the specified decision tree. Additional, complex analysis would be required to try and better define the selected thresholds in order to segregate these more diverse signatures. Thus, this type of approach would likely yield unreasonable computation time and costs when assessing larger regions and the complex cropping scenes such as those found in California.

The use of a computer-assisted classification tool may be beneficial to further discriminate the results. Some of the thresholds determined in the manual method could be utilized with computer-assisted programs like eCognition to create an object-based classification regime. The application of computer-assisted classification tools using eCognition is presented in the following chapter. 


\section{COMPUTER-ASSISTED CLASSIFICATION USING ECOGNITION}

Computer-assisted algorithms can likely decrease the computing time and increase accuracy of classification when compared to a manual method such as the simplified decision tree discussed in Chapter 4. A method that is not only repeatable but also can be performed without a large amount of labor and cost for future classification is highly desirable. This chapter aims to determine the applicability and viability of eCognition as a global classification engine for California crops and its capability to provide a simplistic, user friendly platform for classification.

\subsection{Data Extraction}

As mentioned previously, it is important that the selected training data is representative of the actual crop present so that the classification analysis will be accurate. Chapter 3 provided details regarding data processing and reduction for the Madera (2001 and 2011) and Merced (2002) data sets performed to eliminate bias and erroneous data. The resultant lead to a total crop list of 24 land type classifications (considering the three data sets) which could then be analyzed using the eCognition program. The crop class subset is summarized in Table 5-1. Considering these classes, the refined data set consisted of 8,358 crop fields for the 2001 data (Madera); 5,935 crop fields for the 2011 data (Madera); and 9,959 crop fields for the 2002 data (Merced). A summary of the ground survey data sets for these classes is shown in Table 5-2 with percentage of overall crop types shown in Table 5-3. 
Table 5-1. Crop types used in analysis

\begin{tabular}{|l|l|l|l|}
\hline \multicolumn{4}{|c|}{ Crop Type } \\
\hline Alfalfa & $\begin{array}{l}\text { Fallow/Idle } \\
\text { cropland }\end{array}$ & Pasture/Grass & Sudan \\
\hline Almond & Grapes & Peaches & Sugarbeets \\
\hline Apples & Olives & Pistachio & Corn \\
\hline Christmas Trees & Onions & Plums & Tomatoes \\
\hline Cotton & Orange & Prunes & Walnuts \\
\hline Dry Beans & $\begin{array}{l}\text { Other Hay/Non } \\
\text { Alfalfa }\end{array}$ & Sod/Grass Seed & Watermelons \\
\hline
\end{tabular}

Table 5-2. Field count ground surveyed by DWR

\begin{tabular}{|c|c|c|c|}
\hline Crop Type & $\begin{array}{c}\text { Count of } 2001 \\
\text { DWR Ground } \\
\text { Survey }\end{array}$ & $\begin{array}{c}\text { Count of } 2002 \\
\text { DWR Ground } \\
\text { Survey }\end{array}$ & $\begin{array}{c}\text { Count of } 2011 \\
\text { DWR Ground } \\
\text { Survey }\end{array}$ \\
\hline Alfalfa & 682 & 1810 & 497 \\
\hline Almond & 1487 & 2774 & 2079 \\
\hline Apples & 73 & 18 & 66 \\
\hline Christmas Trees & 25 & 47 & 24 \\
\hline Cotton & 466 & 1503 & 235 \\
\hline Dry Beans & 10 & 21 & 24 \\
\hline Fallow/Idle Cropland & 108 & 125 & 154 \\
\hline Grapes & 3218 & 108 & 1683 \\
\hline Olives & 42 & 319 & 49 \\
\hline Onions & 10 & 3 & 4 \\
\hline Oranges & 153 & 4 & 152 \\
\hline Other Hay/Non Alfalfa & 399 & 3 & 219 \\
\hline Pasture/Grass & 383 & 1269 & 49 \\
\hline Peaches & 143 & 351 & 1 \\
\hline Pistachios & 428 & 1 & 420 \\
\hline Plums & 115 & 4 & 20 \\
\hline Prunes & 37 & 77 & 20 \\
\hline Sod/Grass Seed & 37 & 36 & $\mathrm{n} / \mathrm{a}$ \\
\hline Sudan & 40 & 34 & $\mathrm{n} / \mathrm{a}$ \\
\hline Sugarbeets & 13 & 87 & $\mathrm{n} / \mathrm{a}$ \\
\hline Sweet Corn & 383 & 408 & 129 \\
\hline Tomatoes & 41 & 537 & 52 \\
\hline Walnuts & 52 & 310 & 48 \\
\hline Watermelons & 13 & 110 & 10 \\
\hline Total & 8358 & 9959 & 5935 \\
\hline
\end{tabular}


Table 5-3. Percent of total crops analyzed for 2001 Madera, 2002 Merced, and 2011 Madera Data Sets

\begin{tabular}{|c|c|c|c|}
\hline Crop Type & $\begin{array}{l}\text { Percent of Crop } \\
\text { Types in } 2001 \text { DWR } \\
\text { Ground Survey }\end{array}$ & $\begin{array}{l}\text { Percent of Crop } \\
\text { Types in } 2002 \text { DWR } \\
\text { Ground Survey }\end{array}$ & $\begin{array}{l}\text { Percent of Crop } \\
\text { Types in } 2011 \text { DWR } \\
\text { Ground Survey }\end{array}$ \\
\hline Alfalfa & $8.2 \%$ & $18.2 \%$ & $8.4 \%$ \\
\hline Almond & $17.8 \%$ & $27.9 \%$ & $35.0 \%$ \\
\hline Apples & $0.9 \%$ & $0.2 \%$ & $0.0 \%$ \\
\hline Christmas Trees & $0.3 \%$ & $0.5 \%$ & $0.4 \%$ \\
\hline Cotton & $5.6 \%$ & $15.1 \%$ & $4.0 \%$ \\
\hline Dry Beans & $0.1 \%$ & $0.2 \%$ & $0.4 \%$ \\
\hline Fallow/ldle Cropland & $1.3 \%$ & $1.3 \%$ & $2.6 \%$ \\
\hline Grapes & $38.5 \%$ & $1.1 \%$ & $28.4 \%$ \\
\hline Olives & $1.5 \%$ & $3.2 \%$ & $0.8 \%$ \\
\hline Onions & $0.1 \%$ & $0.0 \%$ & $0.1 \%$ \\
\hline Oranges & $1.8 \%$ & $0.0 \%$ & $2.6 \%$ \\
\hline Other Hay/Non Alfalfa & $4.8 \%$ & $0.0 \%$ & $\mathrm{n} / \mathrm{a}$ \\
\hline Pasture/Grass & $4.6 \%$ & $12.7 \%$ & $3.7 \%$ \\
\hline Peaches & $1.7 \%$ & $3.5 \%$ & $0.8 \%$ \\
\hline Pistachios & $5.1 \%$ & $0.0 \%$ & $7.1 \%$ \\
\hline Plums & $1.4 \%$ & $0.0 \%$ & $0.3 \%$ \\
\hline Prunes & $0.4 \%$ & $0.8 \%$ & $0.3 \%$ \\
\hline Sod/Grass Seed & $0.4 \%$ & $0.4 \%$ & $\mathrm{n} / \mathrm{a}$ \\
\hline Sudan & $0.5 \%$ & $0.3 \%$ & $\mathrm{n} / \mathrm{a}$ \\
\hline Sugarbeets & $0.2 \%$ & $0.9 \%$ & $\mathrm{n} / \mathrm{a}$ \\
\hline Sweet Corn & $4.6 \%$ & $4.1 \%$ & $2.2 \%$ \\
\hline Tomatoes & $0.5 \%$ & $5.4 \%$ & $0.9 \%$ \\
\hline Walnuts & $0.6 \%$ & $3.1 \%$ & $0.8 \%$ \\
\hline Watermelons & $0.2 \%$ & $1.1 \%$ & $0.2 \%$ \\
\hline Total & $100 \%$ & $100 \%$ & $100 \%$ \\
\hline
\end{tabular}




\subsection{Methodology}

Pattern recognition seems to be a combination of art and science: science, in the sense that computer algorithms are utilized to assist classification procedures and art, in that interpretation and training sites are based on user experience and knowledge. Both aspects can greatly affect the outcome of the results. An unsupervised classification model allows for a strictly science analysis determining patterns and classes without any prior user input but will require user analysis to properly interpret the results. A supervised system uses training data based on input from the user and known classes which may narrow the results of the classification test and may be subject to user bias.

\subsection{1 eCognition Analyses}

The computer program eCognition, discussed in Chapter 2, has the capability for supervised or unsupervised models with a set of spectral features as inputs. The spectral signatures can be based on a parametric (statistical parameters) or nonparametric (discrete objects) as the basis or a combination of both (Kloer 1994). The focus of this paper is a supervised model using the Nearest Neighbor (NN) method uses a set of training data (objects with known classes) as a base. The NN method was utilized because the approach is computationally simple (Laliberte et al. 2004). Details of the NN method are provided in Chapter 2. The training samples consisted of sites with known crops based on DWR field survey used as ground truthing. 
A classification algorithm was created with Trimble's eCognition ${ }^{\odot}$ Developer program which utilizes image layers (such as spectral data), thematic layers (such as parcel shape files) and incorporates the Nearest Neighbor algorithm which has been pre-programed within the software package. The user can provide direct input through parent/child process tree organization where results can easily be interrogated and reviewed by the end user. A sample process tree layout in eCognition is provided in Figure 5-1.

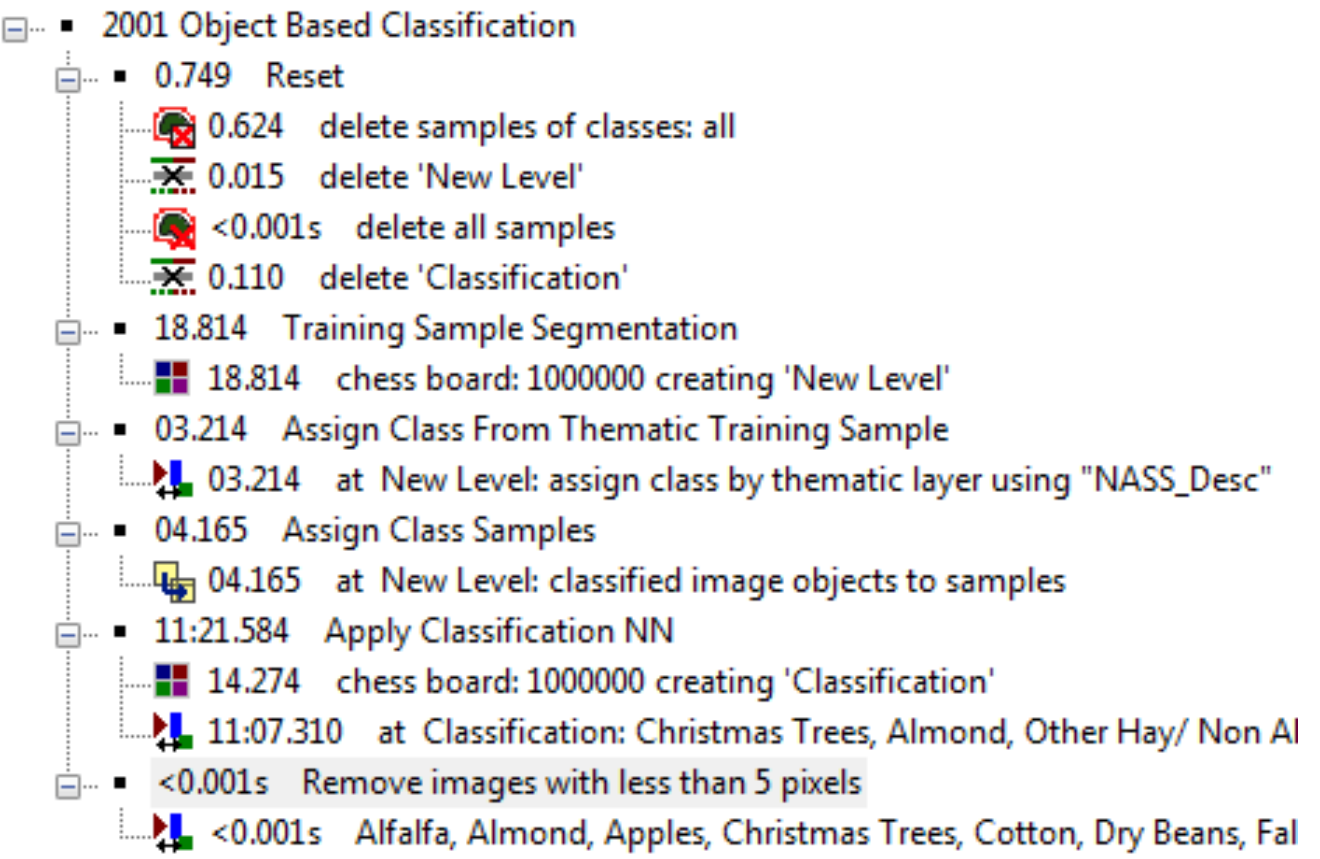

Figure 5-1. eCognition Process Tree Sample 


\subsubsection{Scenarios Considered}

Using the NN classification algorithm in eCognition, a series of four scenarios were analyzed. The four scenarios considered are described below:

Scenario 1: The 2001 Madera, 2002 Merced, 2011 Madera were analyzed using $5 \%, 10 \%, 20 \%$ of the DWR ground survey data as training data for each of the respective years. For example, 2001 Madera analysis utilizes $10 \%$ of the 2001 (Madera) DWR ground survey as ground truthing to create training data for use in the classification algorithm. This scenario reviews the effects of using various percentages of ground truthing as training data used in subsequent analysis. Due to the high cost and labor that may be involved with acquisition of ground survey for future data sets, users should understand the effects of the percentage of training data used. Each county should be re-assessed as they vary in size and quantity of field. For example a field survey aiming to ground truth $20 \%$ of field in a small county may be more feasible than a larger county.

Scenario 2: Scenario 2 reviews the applicability of utilizing the DWR existing ground survey data as a basis to create a comprehensive training sample set from one county that can be applied to a future site for use in the classification algorithm. In this scenario, $90 \%$ of the Madera 2001 ground survey data is used to create a comprehensive training set that is applied to the Merced 2002 and the Madera 2001 study areas. 
Scenario 3: Utilizing the methods and results from Scenario 2, this scenario reviews the effect of adding an additional $10 \%$ of the respective DWR ground survey data (from the subject area and year) to the existing training sample set. For example, $90 \%$ of the 2001 Madera County ground survey is used to create a training sample set as described in scenario 2 and an additional $10 \%$ of DWR ground survey from Merced 2002 data set is applied on the 2002 Merced classification algorithm. The change in accuracy associated with updating a base training sample set (from 2001 Madera) with additional training data points of a subject year is reviewed.

Scenario 4: The vegetation indices presented in the previous sections and utilized for the analysis have all been pre-processed in house by the ITRC. With the dissemination of Landsat data, corrected spectral data are relatively common practice and can be obtained without much effort. The EToF utilized in the analysis is produced by a METRIC created by the ITRC in house. Scenario 4 reviews the effects of the Actual Crop Coefficient feature space on the classification accuracy. For simplicity, only the Madera 2011 data set used in scenario 3 was considered.

\subsubsection{Data Input}

The satellite data dates used for the algorithm feature set are listed in the Table 5-4. During early and late 2011 the land satellite experienced a failure in one of its sensors creating a band gap in the produced data. Interpolation could be applied to compensate the data gap; however, since the interpolated data would 
not be actual data, the satellite dates for early March and late December were omitted from the analysis.

Table 5-4. Satellite dates used for multi-temporal analysis

\begin{tabular}{|l|l|l|l|l|l|}
\hline 2001 Madera & 10-May & 19-Jul & 13-Jul & 14-Aug & 1-Oct \\
\hline 2002 Merced & 5-May & 22-June & 8-July & 9-Aug & 4-Oct \\
\hline 2011 Madera & 6-May & 23-Jul & 9-Jul & 10-Aug & 27-Sep \\
\hline
\end{tabular}

It is important to note that the two data sets data sets from Madera are 10 years apart and that selection of the appropriate satellite acquisition dates greatly affected the accuracy results. It was found that analysis dates (time of year satellite image was taken) needed to match relatively closely for all three data sets. In general, if the dates between the respective satellite data sets were not within 2-5 days of each other, they were removed for analysis.

Feature spaces have been defined in order to create the class hierarchy to be used with the NN algorithm. Initial trials attempted to utilize all the available indices available for the subject data set within eCognition - approximately 14 indices and 14 dates including reflectance and radiance which resulted in approximately $400+$ image layers resulting in the program becoming unstable and having unreasonable processing times.

It is important to note that a feature space can be reviewed and optimized within the eCognition program. Thus, feature space combinations were then analyzed through trial iterations. It was found that a combination of spectral indices and bands including NDVI, NDWI, Albedo, Actual Crop Coefficient, and Radiance 
bands 1 through 7 , resulted in the highest classification accuracy. The combination of these feature spaces for the dates considered (Table 5-4) created a final multi-temporal feature space of 55 images.

Once the final feature space was defined, training samples were extracted and a class hierarchy was defined in eCognition. The class hierarchy used in analysis is presented in Figure 5-2.

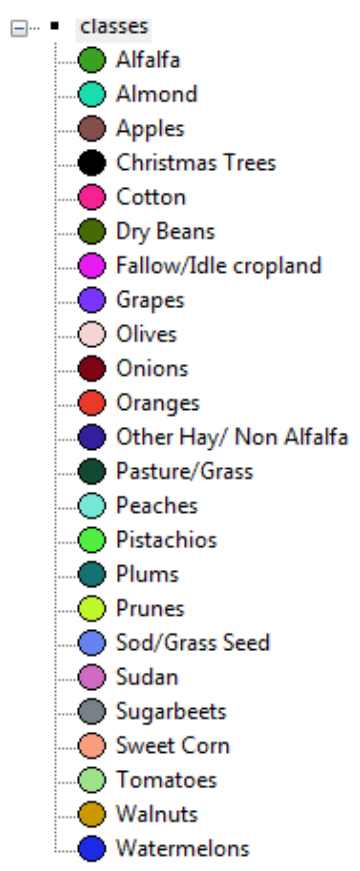

Figure 5-2. eCognition class hierarchy

Figure 5-3 below shows an example from eCognition where 10\% of 2001 Madera data were used as training samples, i.e. Scenario 1. The colored areas correspond to the class symbols lists in Figure 5-2 and represent the 10\% DWR ground surveyed parcels that were used as training data for the NN algorithm. 


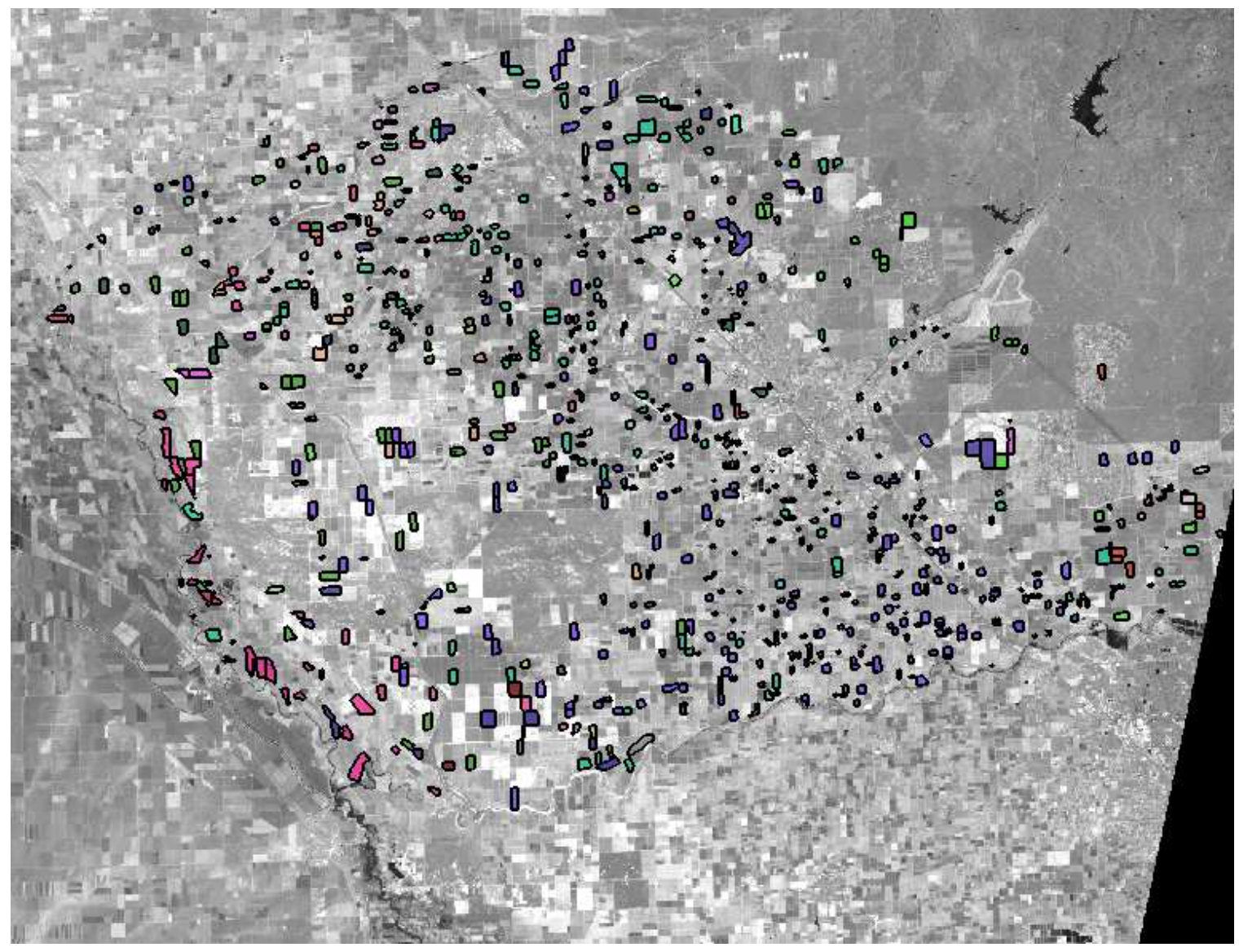

Figure 5-3. 10\% training sample sites for Madera 2001

Once $10 \%$ training data has been input into eCognition, the program then creates a unique spectral signature for each class within the feature space. The sample editor within the program can then be used to compare different spectral signatures. An example of the sample editor is shown in the Figure 5-4 and illustrates the comparison of several different layers that help the $\mathrm{NN}$ algorithm discriminate between Cotton (shown in black) and Alfalfa (shown in blue). 


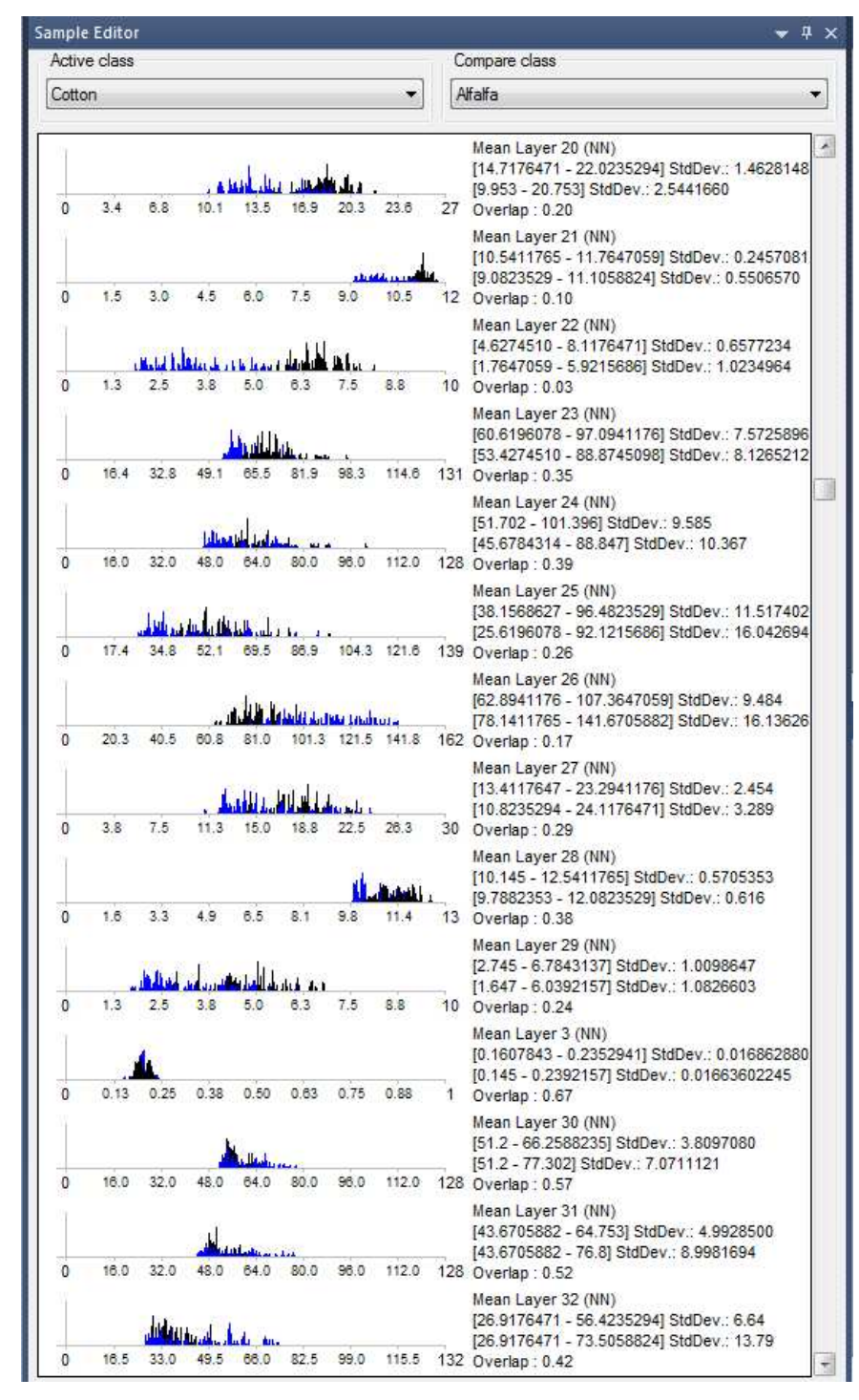

Figure 5-4. Sample editor comparing class feature space created for Cotton (black) and Alfalfa (blue)

Once the samples are populated with a feature space from the imported image data, the program can run the NN classification algorithm. The analysis results in a final classification image, similar to that presented in Figure 5-5. This process was applied to the four scenarios and the results are discussed in the subsequent section. 


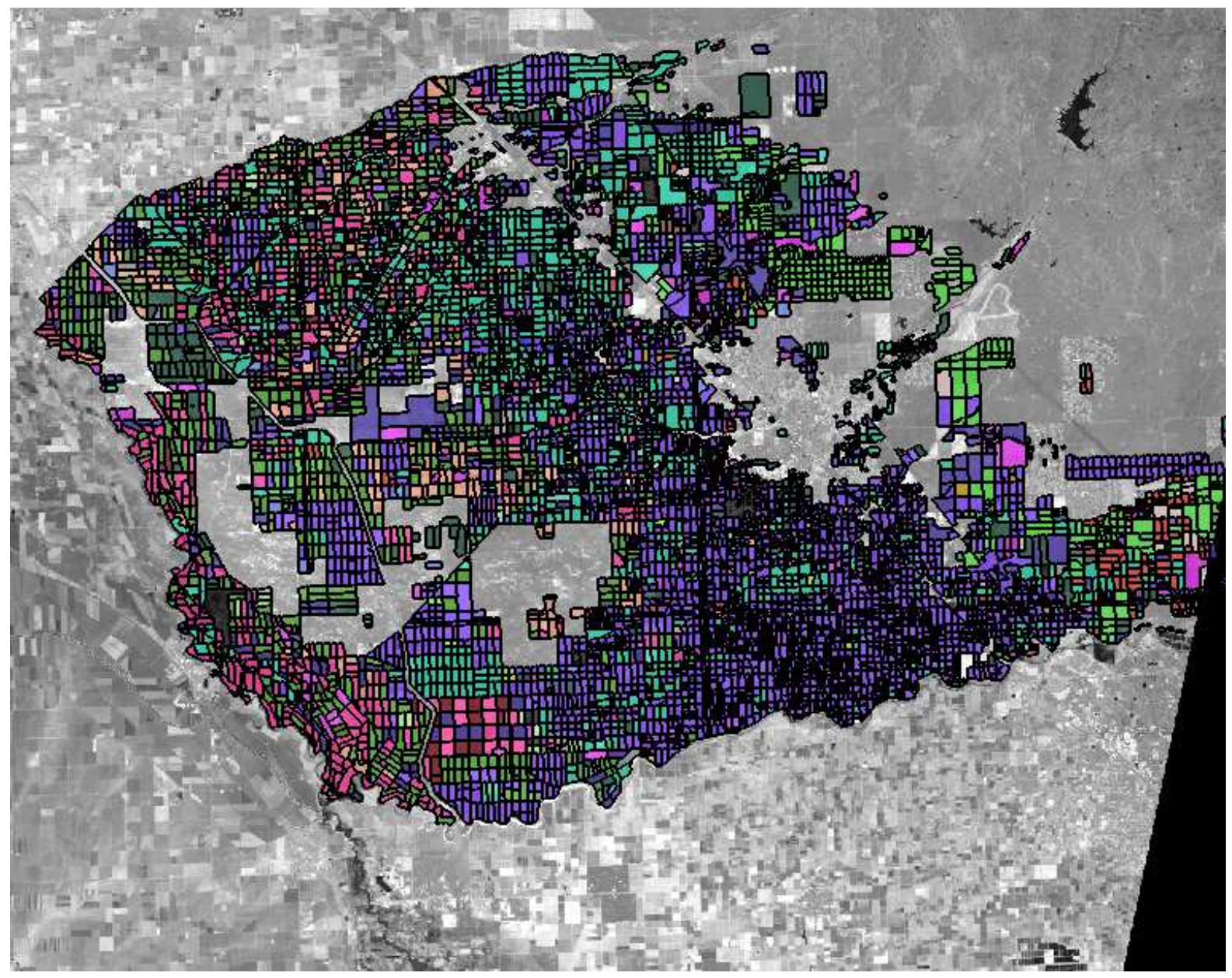

Figure 5-5. Example of final classification results using the NN algorithm in eCognition

\subsection{Results}

Accuracy is essential in determining the performance of a classification scheme and identifying areas where improvements may be required within certain classes. Thus, the results from each scenario are discussed in terms of the accuracy of the algorithm to classify crops according to the DWR ground survey data. 
Individual tables reporting each class (crop type) accuracy are presented in Appendix $D$ for each of the scenarios considered. Confusion matrices of the resulting classifications for each of the four scenarios considered are provided in Appendix E. The overall accuracies (calculated based on field areas) of each of the analyses performed for the respective scenarios are summarized in Table 5-5, followed by a discussion of each. The overall accuracies are based on area.

Table 5-5. Summary of results from eCognition analyses

\begin{tabular}{|c|c|c|c|}
\hline \multirow{2}{*}{ Scenario } & \multicolumn{3}{|c|}{ Overall Accuracy } \\
\cline { 2 - 4 } & 2001 Madera & 2002 Merced & 2011 Madera \\
\hline 1A & $77 \%$ & $69 \%$ & $74 \%$ \\
\hline 1B & $79 \%$ & $73 \%$ & $77 \%$ \\
\hline 1C & $84 \%$ & $78 \%$ & $83 \%$ \\
\hline 2 & - & $60 \%$ & $70 \%$ \\
\hline 3 & - & $75 \%$ & $78 \%$ \\
\hline 4 & - & - & $75 \%$ (no EToF) \\
\hline
\end{tabular}

Scenario 1 involved using a percentage $(5 \%, 10 \%$, and $20 \%$ for $1 \mathrm{~A}, 1 \mathrm{~B}$, and $1 \mathrm{C}$ respectively) of the DWR ground survey data to define training samples and a class hierarchy feature set to be used on the same year with the NN algorithm for 2001 Madera, 2002 Merced, and 2011 Madera data sets. The overall accuracies are summarized in Table 5-5 for the 2001 Madera, 2002 Merced, and 2011 Madera data sets respectively. Individual class accuracies tended to be greater for crops that had a higher percentage of field area present in the county and increased as the percentage of training samples utilized increased. 
In Scenario 2, the 2002 Merced and 2011 Madera data sets were analyzed using training data compiled from $90 \%$ of the 2001 Madera DWR ground survey data imported into the two subject data sets and the $\mathrm{NN}$ classification algorithm was applied. Merced 2002 and Madera 2011 showed a decrease in overall accuracy from the first scenario, resulting in an overall user class accuracy of $60 \%$ and $70 \%$ respectively. This reduction in overall accuracy is believed to be due to the large date gap between the two data sets (10 years) in the same county and spatial differences between the two counties for years with close proximity. Factors that may affect cropping calendars and phenology include: changes in climate, irrigation technology, farming methods, and sensor accuracy.

In an effort to improve the overall accuracy of the 2002 Merced and 2011 Madera data, additional training samples from the respective DWR ground survey data sets were added into the compiled 2001 Madera training samples in Scenario 3. For example, $10 \%$ of the 2011 DWR ground survey data was used to create training data and added to the imported (90\%) 2001 Madera training sample set, resulting in an overall user classification improved accuracy of $78 \%$. With a similar application to the 2002 Merced data set, the overall user classification accuracy increased to $75 \%$. The increase in performance is likely because the additional training data allows the algorithm to overcome changes in phenology and agricultural practices resulting from a large date gap or change in area use. 
The last scenario (Scenario 4) analyzed the overall effect of including the Actual Crop Coefficient, EToF, within the algorithm feature space. It was found the inclusion of the EToF boosted overall user class results by approximately $3.0 \%$, as shown by comparing the results from Scenario $3(78 \%)$ to the overall accuracy with the removal of EToF in Scenario $4(75 \%)$.

\subsection{Discussion}

It is understood that selection of appropriate training samples, suitability of classification algorithm and selection of spectral inputs used for analysis is critical for successful classification (Lu and Weng 2007). Although the DWR assure high accuracy on ground survey data, it is noted that errors in field verifications are inevitable and likely present in the data sets used for the analyses presented. Since the ground truthing data was performed by the DWR separately, quality control for training samples was not performed and may be a source of error in the crop classification. Further double cropping was not considered and could expand the potential for increase error.

As mentioned previously, it was found that it was incredibly important that the dates input into eCognition that make up the feature space be similar across the data sets considered. For example, if a spectral image for NDVI during May $5^{\text {th }}$ was used for sampling in the 2001 Madera data set, it was critical that a similar date (generally found with 4-5 days) was used for the 2011 Merced analysis. Since it is likely that cropping calendars for a specific crop type may not change 
significantly, similar dates improved results likely because the growth and harvest cycles were captured at similar times. Factors such as irrigation practice, farming methods, technological advancement, and changes in climate, may vary greatly between time of data acquisition for a given area (i.e. 2001 Madera versus 2011 Madera). Thus, if the time between data sets for a given area were closer together, the overall accuracy of the tested algorithms would likely increase.

\subsection{Conclusion}

A large crop list in California makes it very difficult to create a classification scheme that can identify all crop types with confidence. Much effort is required to acquire quality training data for use in supervised classification algorithms since crops can vary greatly geographically within California. The acquisition of highly accurate ground truthing would likely be labor intensive and expensive.

As mentioned previously, DWR ground survey is only available for each county in California every 5-10 years, at best, which presents a gap in cataloging of crop types in the region. The research presented in this chapter utilized DWR ground survey as training samples for input into the $\mathrm{NN}$ algorithm within the program eCognition. The program is capable of handling large image data sets.

Madera County 2001 and 2011 and Merced County 2002 data were analyzed because the DWR has ground survey available and the ITRC has pre-processed 
Landsat images for the subject years. The subject data set was reduced to agricultural crops that were present in the County and non-agriculture land types were removed, as discussed in Chapter 3.

When the NN algorithm was applied using $5 \%, 10 \%$, and $20 \%$ of each crop type as training data for the respective data set, overall user classification accuracies ranged between $77 \%$ to $83 \%$ depending on the percentage of training samples used in the analysis. It was found that an increase in training samples generally increase the overall accuracy of the analysis. When applying only 90\% 2001 Madera training data to the 2011 Madera and 2002 Merced data sets resulted in a decreased overall accuracy. However, coupling the 90\% 2001 Madera training data with $10 \%$ training data from the respective data sets, resulted to improved classification accuracies of 75\% (2002 Merced) and 78\% (2011 Madera). Lastly, the exclusion of the Actual Crop Coefficient, EToF, was found to decrease the overall accuracy by $3 \%$ when considering the 2011 Madera data set in the scenario 3 analysis.

In conclusion, the results show there are clear advantages of using an algorithmbased approaches to classify crop types. It was demonstrated that historical ground survey data provided by DWR can be used with future imagery datasets to obtain reasonable classification results. Crops types with larger population within a county had the highest classification accuracy. This is likely due to the larger 
sample number within the dataset overcoming small biases associated with poor training data. 


\section{CONCLUSIONS}

With the high cost of physical ground survey there is an absolute need for an accurate, inexpensive methodology to identify crop types in California through remote sensing. This research has focused on an area of the Central Valley, the Madera and Merced Counties, in an effort to develop an improved approach to crop classification using available Landsat and DWR data.

The results of this study have shown the use of a manual simplified decision tree approach (DT) or computer-assisted approach, using the Nearest Neighbor (NN) algorithm within eCognition, may be sufficient in the classification of certain crops. However, both methods presented have associated shortcomings and when considered individually, each have difficulty in classifying all of the crop types within the areas considered.

It is hypothesized that a combination of multiple approaches discussed and/or presented in this research such as classical decision trees, phenology-based approach, or computer-assisted algorithms could result in an improved overall classification of crop types. For example, the use of the $\mathrm{NN}$ algorithm within eCognition resulted in acceptable results for major crops types present within the subject data sets and it is suggested that alternate methods such as manual classification, phonology based, or SVM (to name a few) be incorporated into the classification scheme to better discriminate among all the remaining crop types. Ultimately, the hybrid approach will need to be capable of capturing single and 
multiple crop rotation within a field and be diverse enough to capture the constantly changing climate conditions and farming practices.

As accuracy, resolution and confidence in Landsat imagery increases, a method to comprehensively classify and catalog crops in California at any time can provide many uses. In California, during times of drought, groundwater basins are being over drafted. Accurate crop classification can help improve water balance calculations for agricultural and environmental habitat and contribute to planning and policy decision making. Further use of an improved classification system can be applied on a global scale to land use changes and assessment of non-point source contamination loading.

\subsection{Comparison to CDL}

The United States Department of Agriculture (USDA) National Agricultural Statistics Service (NASS) provides a geo-referenced, crop-specific land cover data product called the Cropland Data Layer (CDL). The main goals of the CDL are to provide 1) supplemental acreage estimates and 2) produce geo-referenced crop specific products on an annual basis. The product is a pixel-based raster image processed and analyzed by the Spatial Analysis Research Section (SARS) and is available for the State of California after 2007.

CDL accuracies tend to be higher in areas where only a few crops are dominant and in areas such California where crop types are diverse and complex, 
classification accuracies of the CDL would likely be much lower. Reitsma et al. (2016) reported CDL accuracies in South Dakota that ranged from $38.9 \%$ to $95.2 \%$ for an analysis classifying grasslands. They attributed the wide range of accuracy to the intrinsic errors associated within $\mathrm{CDL}$ and noted that the highest accuracies occurred when the subject fields were dominantly present and conversely, lower accuracy's occurred when a single crop was less dominantly practiced. Similarly Larsen et al. (2015) compared area estimates for major US crops in 2012 and found that accuracy of the CDL is extremely variable and influenced greatly by the variability of crops present.

The 2011 Madera CDL raster image was downloaded from the CropScape web interface for comparison against the 2011 Madera County DWR ground survey. The CDL was pre-processed within the ArcGIS computer program and reduced to a similar 24 crop type subset of as described in section 5. The 2011 Madera County CDL resulted an overall accuracy of $67.1 \%$ when compared against the 2011 Madera County DWR ground survey as summarized in Table 6-1. The 2011 Madera (scenario 3) accuracies determined from eCognition's Nearest Neighbor algorithm and the quantity of fields utilized as training data in the 2011 Madera (scenario 3) analysis are included in for reference. 
Table 6-1. Accuracy comparison of 2011 Madera CDL versus 2011 Madera (scenario 3) analysis

\begin{tabular}{|l|c|c|c|}
\hline Crop Type & $\begin{array}{c}2011 \text { Madera } \\
\text { (scenario 3) } \\
\text { Accuracy }\end{array}$ & $\begin{array}{c}\text { Qty of fields used as training } \\
\text { data in 2011 Madera } \\
\text { (scenario 3) Analysis }\end{array}$ & $\begin{array}{c}\text { 2011 Madera } \\
\text { Cropscape CDL } \\
\text { Accuracy }\end{array}$ \\
\hline Alfalfa & $86.5 \%$ & 663 & $94.3 \%$ \\
\hline Almond & $85.5 \%$ & 1548 & $85.6 \%$ \\
\hline Apples & $7.7 \%$ & 72 & $0.0 \%$ \\
\hline Christmas Trees & $7.5 \%$ & 24 & $0.0 \%$ \\
\hline Corn & $89.4 \%$ & 357 & $54.6 \%$ \\
\hline Cotton & $69.9 \%$ & 443 & $57.8 \%$ \\
\hline Dry Beans & $4.2 \%$ & 11 & $0.0 \%$ \\
\hline Fallow/Idle cropland & $31.7 \%$ & 113 & $69.0 \%$ \\
\hline Grapes & $84.1 \%$ & 3064 & $77.3 \%$ \\
\hline Olives & $3.5 \%$ & 42 & $25.9 \%$ \\
\hline Onions & $15.0 \%$ & 10 & $0.0 \%$ \\
\hline Oranges & $56.6 \%$ & 153 & $52.7 \%$ \\
\hline Pasture/Grass & $59.1 \%$ & 367 & $0.0 \%$ \\
\hline Peaches & $0.0 \%$ & 134 & $0.0 \%$ \\
\hline Pistachios & $63.2 \%$ & 427 & $63.3 \%$ \\
\hline Plums & $29.6 \%$ & 105 & $0.0 \%$ \\
\hline Prunes & $24.1 \%$ & 35 & $0.0 \%$ \\
\hline Sod/Grass Seed & $\mathrm{n} / \mathrm{a}$ & 39 & $0.0 \%$ \\
\hline Sudan & $\mathrm{n} / \mathrm{a}$ & 0 & $\mathrm{n} / \mathrm{a}$ \\
\hline Sugarbeets & $\mathrm{n} / \mathrm{a}$ & 0 & $74.3 \%$ \\
\hline Tomatoes & $69.4 \%$ & 52 & $0.0 \%$ \\
\hline Walnuts & $27.9 \%$ & 12 & \\
\hline Watermelons & $12.5 \%$ & $72 \%$ & \\
\hline \hline Overall Accuracy & $78.0 \%$ & & \\
\hline & & 39 & \\
\hline
\end{tabular}


The overall accuracy determined for the 2011 Madera County CDL is approximately $3.3 \%$ lower than the accuracy for the Scenario 3 analysis. Further, the CDL tends to have similar accuracies for the five dominant crop types (grapes, almond, alfalfa, cotton and pistachios) when compared to the Scenario 3 analysis. It is thought that because these five crops had some of the highest acreage and field presence in Madera County during 2011, the CDL is able to provide an acceptable classification accuracy. Other crops reviewed that do not have dominating field presence tended to show highly variable accuracies and it is hypothesized that in general, the $\mathrm{CDL}$ is more appropriate for identifying crop types with large dominance within a study area; however, in California the overall accuracy remains low due to the large diversity of crop types in the Central Valley.

\subsection{Future Work}

Largely due to the complexity of California crop types, future improvement to the presented classification schemes could incorporate a hybrid approach which combines the power of the computer based analysis with alternative methods, such as those discussed in this thesis: decision tree, phenology-based approach, and computer-assisted algorithms.

The decisions tree approach would may be more applicable to classifying general crop types at initial levels such as a crop versus non crop or tree crop versus ground crop level of analysis. As discussed in Chapter 4, as the decision tree grows spectral signatures of crop types become more similar making this approach 
less effective. At this stage the use of a computer-assisted algorithms such as eCognition could be applied in an attempt to classify crop types with a large field presence within the data set. Further, since the phenology-based classification approach is less reliant on training data and more reliant on cropping calendars, the inclusion this algorithm may be used to help discriminate crops with less fields present in a study area and that have defined cropping calendars.

This research suggests that eCognition could provide a promising platform for future analysis. Continued iterations of the algorithms within eCognition may lead to even better accuracy but this was considered beyond the scope of the thesis. The suggested hybrid approach combined with future efforts should further evaluate other methods not considered in this research such as CART, SVM, and Neural Networks. 


\section{REFERENCES}

Bischof, H., W. Schneider and A. J. Pinz. 1992. Multispectral classification of Landsat-images using neural networks. IEEE Transactions On Geoscience and Remote Sensing 30(3): 482-490.

Blaschke, T. 2010. Object based image analysis for remote sensing. ISPRS journal of photogrammetry and remote sensing 65(1): 2-16.

Boryan, C. and M. Craig. 2005. Multiresolution Landsat TM and AWiFS sensor assessment for crop area estimation in Nebraska. Proceedings from Pecora 16: 22-27 Sioux Falls, South Dakota.

Burt, C. M. 1999. Irrigation water balance fundamentals. Bioresource and Agricultural Engineering: 53.

Crist, E. P. 1985. A TM tasseled cap equivalent transformation for reflectance factor data. Remote Sensing of Environment 17(3): 301-306.

De Fries, R., M. Hansen, J. Townshend and R. Sohlberg. 1998. Global land cover classifications at $8 \mathrm{~km}$ spatial resolution: the use of training data derived from Landsat imagery in decision tree classifiers. International Journal of Remote Sensing 19(16): 3141-3168. 
De Santa Olalla, F. M. n., A. Calera and A. Domınguez. 2003. Monitoring irrigation water use by combining Irrigation Advisory Service, and remotely sensed data with a geographic information system. Agricultural water management 61(2): 111-124.

DeFries, R. and J. C.-W. Chan. 2000. Multiple criteria for evaluating machine learning algorithms for land cover classification from satellite data. Remote Sensing of Environment 74(3): 503-515.

Dinar, A. and D. Zilberman. 1991. The economics of resource-conservation, pollution-reduction technology selection: the case of irrigation water. Resources and energy 13(4): 323-348.

Doraiswamy, P., J. Hatfield, T. Jackson, B. Akhmedov, J. Prueger and A. Stern. 2004. Crop condition and yield simulations using Landsat and MODIS. Remote sensing of environment 92(4): 548-559.

Foody, G. M. 2002. Status of land cover classification accuracy assessment. Remote Sensing of Environment 80(1): 185-201.

Friedl, M., C. E. Brodley and A. H. Strahler. 1999. Maximizing land cover classification accuracies produced by decision trees at continental to global 
scales. IEEE Transactions On Geoscience and Remote Sensing 37(2): 969-977.

Friedl, M. A. and C. E. Brodley. 1997. Decision tree classification of land cover from remotely sensed data. Remote Sensing of Environment 61(3): 399409.

Geospatial, T. 2016. eCognition Developer 9.

Gopal, S. and C. Woodcock. 1996. Remote sensing of forest change using artificial neural networks. Geoscience and Remote Sensing, IEEE Transactions on 34(2): 398-404.

Han, W., Z. Yang, L. Di and R. Mueller. 2012. CropScape: A Web service based application for exploring and disseminating US conterminous geospatial cropland data products for decision support. Computers and Electronics in Agriculture 84: 111-123.

Hansen, M., R. DeFries, J. R. Townshend and R. Sohlberg. 2000. Global land cover classification at $1 \mathrm{~km}$ spatial resolution using a classification tree approach. International journal of remote sensing 21(6-7): 1331-1364. 
Hansen, M., R. Dubayah and R. DeFries. 1996. Classification trees: an alternative to traditional land cover classifiers. International Journal of Remote Sensing 17(5): 1075-1081.

Hansen, M. C. and T. R. Loveland. 2012. A review of large area monitoring of land cover change using Landsat data. Remote Sensing of Environment 122: 66-74.

Holben, B. N. 1986. Characteristics of maximum-value composite images from temporal AVHRR data. International Journal of Remote Sensing 7(11): $1417-1434$

Huang, C., L. Davis and J. Townshend. 2002. An assessment of support vector machines for land cover classification. International Journal of Remote Sensing 23(4): 725-749.

Huang, C., B. Wylie, L. Yang, C. Homer and G. Zylstra. 2002. Derivation of a tasselled cap transformation based on Landsat 7 at-satellite reflectance. International Journal of Remote Sensing 23(8): 1741-1748.

Kandrika, S. and P. S. Roy. 2008. Land use land cover classification of Orissa using multi-temporal IRS-P6 awifs data: A decision tree approach. 
International Journal of Applied Earth Observation and Geoinformation 10(2): 186-193.

Kauth, R. J. and G. Thomas (1976). The tasselled cap--a graphic description of the spectral-temporal development of agricultural crops as seen by Landsat. LARS Symposia.

Kloer, B. R. (1994). Hybrid parametric/non-parametric image classification. Technical Papers, ACSM-ASPRS Annual Convention.

Laliberte, A. S., M. A. Goforth, C. M. Steele and A. Rango. 2011. Multispectral remote sensing from unmanned aircraft: Image processing workflows and applications for rangeland environments. Remote Sensing 3(11): 25292551.

Laliberte, A. S., A. Rango, K. M. Havstad, J. F. Paris, R. F. Beck, R. McNeely and A. L. Gonzalez. 2004. Object-oriented image analysis for mapping shrub encroachment from 1937 to 2003 in southern New Mexico. Remote Sensing of Environment 93(1): 198-210.

Larsen, A. E., B. T. Hendrickson, N. Dedeic and A. J. MacDonald. 2015. Taken as a given: Evaluating the accuracy of remotely sensed crop data in the USA. Agricultural Systems 141: 121-125. 
Lu, D. and Q. Weng. 2006. Use of impervious surface in urban land-use classification. Remote Sensing of Environment 102(1): 146-160.

Lu, D. and Q. Weng. 2007. A survey of image classification methods and techniques for improving classification performance. International journal of Remote Sensing 28(5): 823-870.

Martínez-Casasnovas, J. A., A. Martín-Montero and M. A. Casterad. 2005. Mapping multi-year cropping patterns in small irrigation districts from timeseries analysis of Landsat TM images. European Journal of Agronomy 23(2): 159-169.

McFeeters, S. K. 1996. The use of the Normalized Difference Water Index (NDWI) in the delineation of open water features. International Journal of Remote Sensing 17(7): 1425-1432.

Melgani, F. and L. Bruzzone. 2004. Classification of hyperspectral remote sensing images with support vector machines. Geoscience and Remote Sensing, IEEE Transactions on 42(8): 1778-1790. 
Michaelsen, J., D. S. Schimel, M. A. Friedl, F. W. Davis and R. C. Dubayah. 1994. Regression tree analysis of satellite and terrain data to guide vegetation sampling and surveys. Journal of Vegetation Science 5(5): 673-686.

Mountrakis, G., J. Im and C. Ogole. 2011. Support vector machines in remote sensing: A review. ISPRS Journal of Photogrammetry and Remote Sensing 66(3): 247-259.

Murakami, T., S. Ogawa, N. Ishitsuka, K. Kumagai and G. Saito. 2001. Crop discrimination with multitemporal SPOT/HRV data in the Saga Plains, Japan. International Journal of Remote Sensing 22(7): 1335-1348.

Myneni, R. B., F. G. Hall, P. J. Sellers and A. L. Marshak. 1995. The interpretation of spectral vegetation indexes. IEEE Transactions on Geoscience and Remote Sensing 33(2): 481-486.

Nath, S. S., G. Mishra, J. Kar, S. Chakraborty and N. Dey (2014). A Survey of Image Classification Methods and Techniques. 2014 International Conference on Control, Instrumentation, Communication and Computational Technologies (ICCICCT). IEEE. Thucklalay, India., IEEE.

Otukei, J. and T. Blaschke. 2010. Land cover change assessment using decision trees, support vector machines and maximum likelihood classification 
algorithms. International Journal of Applied Earth Observation and Geoinformation 12: S27-S31.

Pal, M. and P. M. Mather (2001). Decision tree based classification of remotely sensed data. Paper presented at the 22nd Asian Conference on Remote Sensing, Singapore.

Price, K. P., S. L. Egbert, M. D. Nellis, R.-Y. Lee and R. Boyce. 1997. Mapping land cover in a high plains agro-ecosystem using a multidate Landsat thematic mapper modeling approach. Transactions of the Kansas Academy of Science (1903): 21-33.

Quinlan, J. R. 1993. C4. 5: programs for machine learningMorgan Kaufmann, San Mateo, California.

Reitsma, K. D., D. E. Clay, S. A. Clay, B. H. Dunn and C. Reese. 2016. Does the US Cropland Data Layer Provide an Accurate Benchmark for Land-Use Change Estimates? Agronomy Journal 108(1): 266-272.

Ridd, M. K. 1995. Exploring a VIS (vegetation-impervious surface-soil) model for urban ecosystem analysis through remote sensing: comparative anatomy for cities. International Journal of Remote Sensing 16(12): 2165-2185. 
Running, S. W., T. R. Loveland, L. L. Pierce, R. Nemani and E. Hunt. 1995. A remote sensing based vegetation classification logic for global land cover analysis. Remote Sensing of Environment 51(1): 39-48.

Shimabukuro, Y. E. and J. Smith. 1991. The least-squares mixing models to generate fraction images derived from remote sensing multispectral data. IEEE Transactions On Geoscience and Remote Sensing 29(1): 16-20.

Soudani, K., G. le Maire, E. Dufrêne, C. François, N. Delpierre, E. Ulrich and S. Cecchini. 2008. Evaluation of the onset of green-up in temperate deciduous broadleaf forests derived from Moderate Resolution Imaging Spectroradiometer (MODIS) data. Remote Sensing of Environment 112(5): 2643-2655.

Stumpf, A. and N. Kerle. 2011. Object-oriented mapping of landslides using Random Forests. Remote Sensing of Environment 115(10): 2564-2577.

Toan, T. L., F. Ribbes, L.-F. Wang, N. Floury, K.-H. Ding, J. A. Kong, M. Fujita and T. Kurosu. 1997. Rice crop mapping and monitoring using ERS-1 data based on experiment and modeling results. Geoscience and Remote Sensing, IEEE Transactions on 35(1): 41-56. 
Townshend, J., C. Justice, W. Li, C. Gurney and J. McManus. 1991. Global land cover classification by remote sensing: present capabilities and future possibilities. Remote Sensing of Environment 35(2): 243-255.

Tso, B. and P. Mather. 1999. Crop discrimination using multi-temporal SAR imagery. International Journal of Remote Sensing 20(12): 2443-2460.

Tucker, C. J. 1979. Red and photographic infrared linear combinations for monitoring vegetation. Remote sensing of Environment 8(2): 127-150.

Turker, M. and M. Arikan. 2005. Sequential masking classification of multitemporal Landsat7 ETM+ images for field-based crop mapping in Karacabey, Turkey. International Journal of Remote Sensing 26(17): 38133830.

Van Dijk, A., S. Callis, C. Sakamoto and W. Decker. 1987. Smoothing vegetation index profiles: An alternative method for reducing radiometric disturbance in NOAA/AVHRR data. Photogrammetric Engineering and Remote Sensing 53(8): 1059-1067.

Vieira, I. C. G., A. S. de Almeida, E. A. Davidson, T. A. Stone, C. J. R. de Carvalho and J. B. Guerrero. 2003. Classifying successional forests using Landsat 
spectral properties and ecological characteristics in eastern Amazonia. Remote Sensing of Environment 87(4): 470-481.

Vogelmann, J., T. Sohl, P. Campbell and D. Shaw. 1998. Regional land cover characterization using Landsat Thematic Mapper data and ancillary data sources. Environmental Monitoring and Assessment 51(1-2): 415-428.

Wall, S. L., R. W. Thomas, C. E. Brown and E. H. Bauer. 1984. Landsat-based inventory system for agriculture in California. Remote Sensing of Environment 14(1): 267-278.

Wang, F. 1990. Fuzzy supervised classification of remote sensing images. IEEE Transactions On Geoscience and Remote Sensing 28(2): 194-201.

Yan, L. and D. Roy. 2014. Automated crop field extraction from multi-temporal Web Enabled Landsat Data. Remote Sensing of Environment 144: 42-64.

Yuan, F. and M. E. Bauer. 2007. Comparison of impervious surface area and normalized difference vegetation index as indicators of surface urban heat island effects in Landsat imagery. Remote Sensing of Environment 106(3): 375-386. 
Zhang, X., M. A. Friedl, C. B. Schaaf, A. H. Strahler, J. C. Hodges, F. Gao, B. C. Reed and A. Huete. 2003. Monitoring vegetation phenology using MODIS. Remote sensing of environment 84(3): 471-475.

Zhong, L., P. Gong and G. S. Biging. 2012. Phenology-based crop classification algorithm and its implications on agricultural water use assessments in California's Central Valley. Photogrammetric Engineering \& Remote Sensing 78(8): 799-813.

Zilberman, D., N. MacDougall and F. Shah. 1994. Changes in water allocation mechanisms for California agriculture. Agribusiness: 1. 


\section{Appendix A. Madera 2001 DWR to NASS ID conversion}

\begin{tabular}{|c|c|c|c|c|c|}
\hline $\begin{array}{l}\text { CLASS } \\
1\end{array}$ & $\begin{array}{l}\text { SUBCLASS } \\
1\end{array}$ & $\begin{array}{l}\text { Lookup } \\
\text { ID }\end{array}$ & DWR Description & NASS Description & $\begin{array}{l}\text { NASS ID } \\
\text { Value }\end{array}$ \\
\hline G & 1 & G1 & Barley & Barley & 21 \\
\hline G & 2 & $\mathrm{G} 2$ & Wheat & Spring Wheat & 23 \\
\hline $\bar{G}$ & 3 & G3 & Oats & Oats & 28 \\
\hline G & 6 & G6 & $\begin{array}{l}\text { Misc and mixed } \\
\text { grain and hay }\end{array}$ & Other Hay/Non Alfalfa & 37 \\
\hline G & 99 & G99 & $\begin{array}{l}\text { Unknown mixed } \\
\text { grain and hay }\end{array}$ & Other Hay/ Non Alfalfa & 37 \\
\hline $\mathrm{R}$ & 1 & R1 & Rice & Rice & 3 \\
\hline $\mathrm{F}$ & 1 & F1 & Cotton & Cotton & 2 \\
\hline $\mathrm{F}$ & 2 & F2 & Safflower & Safflower & 33 \\
\hline $\mathrm{F}$ & 3 & F3 & Flax & Flaxseed & 32 \\
\hline $\mathrm{F}$ & 4 & F4 & Hops & Hops & 56 \\
\hline $\mathrm{F}$ & 5 & F5 & Sugar Beets & Sugar beets & 41 \\
\hline $\mathrm{F}$ & 6 & F6 & $\begin{array}{l}\text { Corn (field and } \\
\text { sweet) }\end{array}$ & Corn & 12 \\
\hline $\mathrm{F}$ & 7 & F7 & Grain sorghum & Sorghum & 4 \\
\hline $\mathrm{F}$ & 8 & F8 & Sudan & Sorghum & 4 \\
\hline $\mathrm{F}$ & 9 & F9 & Castor Beans & Dry Beans & 42 \\
\hline $\mathrm{F}$ & 10 & F10 & Beans (dry) & Dry Beans & 42 \\
\hline $\mathrm{F}$ & 11 & F11 & Miscellaneous field & Pasture/Grass & 62 \\
\hline $\mathrm{F}$ & 12 & F12 & Sunflowers & Sunflower & 6 \\
\hline $\mathrm{F}$ & 99 & F99 & $\begin{array}{l}\text { Unknown Field } \\
\text { Crop }\end{array}$ & Safflower & 33 \\
\hline$P$ & 1 & $\mathrm{P} 1$ & $\begin{array}{l}\text { Alfalfa \& alfalfa } \\
\text { mixtures }\end{array}$ & Alfalfa & 36 \\
\hline$P$ & 2 & P2 & Clover & Clover/Wildflower & 58 \\
\hline $\mathrm{P}$ & 3 & P3 & Mixed pasture & Pasture/Grass & 62 \\
\hline $\mathrm{P}$ & 4 & P4 & Native Pasture & Pasture/Grass & 62 \\
\hline $\mathrm{P}$ & 5 & P5 & $\begin{array}{l}\text { Induced high water } \\
\text { table native } \\
\text { pasture }\end{array}$ & Pasture/Grass & 62 \\
\hline $\mathrm{P}$ & 6 & P6 & $\begin{array}{l}\text { Misc. grasses } \\
\text { (normally grown } \\
\text { from seed) }\end{array}$ & Pasture/Grass & 62 \\
\hline$P$ & 7 & P7 & Turf farm & Sod/Grass Seed & 59 \\
\hline $\mathrm{P}$ & 99 & P99 & Unknown Pasture & Pasture/Grass & 62 \\
\hline$T$ & 1 & T1 & Artichokes & Asparagus & 207 \\
\hline$T$ & 2 & T2 & Asparagus & Asparagus & 207 \\
\hline$T$ & 3 & T3 & Beans (green) & Dry Beans & 42 \\
\hline $\mathrm{T}$ & 4 & $\mathrm{~T} 4$ & $\begin{array}{l}\text { Cole crop (when } \\
\text { further breakdown } \\
\text { is not needed) }\end{array}$ & Pasture/Grass & 62 \\
\hline$T$ & 5 & T5 & Unknown & Misc. Vegs \& Fruits & 47 \\
\hline$T$ & 6 & T6 & Carrots & Carrots & 206 \\
\hline$T$ & 7 & $\mathrm{T7}$ & Celery & Celery & 245 \\
\hline$T$ & 8 & T8 & Lettuce (all types) & Lettuce & 227 \\
\hline $\mathrm{T}$ & 9 & T9 & $\begin{array}{l}\text { Melons, squash, } \\
\text { and cucumbers (all } \\
\text { types) }\end{array}$ & Watermelons & 48 \\
\hline$T$ & 10 & T10 & Onions and garlic & Onions & 49 \\
\hline$T$ & 11 & T11 & Peas & Peas & 53 \\
\hline $\begin{array}{l}\text { CLASS } \\
1\end{array}$ & $\begin{array}{l}\text { SUBCLASS } \\
1\end{array}$ & $\begin{array}{l}\text { Lookup } \\
\text { ID }\end{array}$ & DWR Description & NASS Description & $\begin{array}{l}\text { NASS ID } \\
\text { Value }\end{array}$ \\
\hline
\end{tabular}




\begin{tabular}{|c|c|c|c|c|c|}
\hline$T$ & 12 & T12 & Potatoes & Potatoes & 43 \\
\hline$T$ & 13 & T13 & Sweet Potatoes & Sweet Potatoes & 46 \\
\hline$T$ & 14 & T14 & Spinach & Greens & 219 \\
\hline$T$ & 15 & T15 & Tomatoes & Tomatoes & 54 \\
\hline $\mathrm{T}$ & 16 & T16 & $\begin{array}{l}\text { Flowers, nursery \& } \\
\text { Christmas tree } \\
\text { farms }\end{array}$ & Christmas Trees & 70 \\
\hline $\mathrm{T}$ & 17 & T17 & $\begin{array}{l}\text { Mixed (four or } \\
\text { more) }\end{array}$ & Misc. Vegs \& Fruits & 47 \\
\hline $\mathrm{T}$ & 18 & T18 & $\begin{array}{l}\text { Miscellaneous } \\
\text { truck }\end{array}$ & Misc. Vegs \& Fruits & 47 \\
\hline$T$ & 19 & T19 & Bush berries & Blueberries & 242 \\
\hline$T$ & 20 & T20 & Strawberries & Strawberries & 221 \\
\hline $\mathrm{T}$ & 21 & T21 & $\begin{array}{l}\text { Peppers (chili, bell, } \\
\text { etc.) }\end{array}$ & Peppers & 216 \\
\hline$T$ & 22 & T22 & Broccoli & Broccoli & 214 \\
\hline$T$ & 23 & T23 & Cabbage & Cabbage & 243 \\
\hline$T$ & 24 & T24 & Cauliflower & Cauliflower & 244 \\
\hline$T$ & 25 & T25 & Brussels Sprouts & Asparagus & 207 \\
\hline $\mathrm{T}$ & 99 & T99 & $\begin{array}{l}\text { Unknown truck, } \\
\text { nursery, and berry } \\
\text { crops }\end{array}$ & Misc. Vegs \& Fruits & 47 \\
\hline $\mathrm{D}$ & 1 & D1 & Apples & Apples & 68 \\
\hline $\mathrm{D}$ & 2 & $\mathrm{D} 2$ & Apricots & Apricots & 223 \\
\hline $\mathrm{D}$ & 3 & D3 & Cherries & Cherries & 66 \\
\hline D & 5 & D5 & $\begin{array}{l}\text { Peaches and } \\
\text { nectarines }\end{array}$ & Peaches & 67 \\
\hline $\mathrm{D}$ & 6 & D6 & Pears & Pears & 77 \\
\hline $\mathrm{D}$ & 7 & D7 & Plums & Plums & 220 \\
\hline $\mathrm{D}$ & 8 & D8 & Prunes & Prunes & 210 \\
\hline $\mathrm{D}$ & 9 & D9 & Figs & Other Tree crop & 71 \\
\hline D & 10 & D10 & $\begin{array}{l}\text { Miscellaneous } \\
\text { deciduous }\end{array}$ & Deciduous Forest & 141 \\
\hline $\mathrm{D}$ & 12 & D12 & Almonds & Almond & 75 \\
\hline $\mathrm{D}$ & 13 & D13 & Walnuts & Walnuts & 76 \\
\hline $\mathrm{D}$ & 14 & D14 & Pistachios & Pistachios & 204 \\
\hline $\mathrm{D}$ & 99 & D99 & Unknown tree crop & Other Tree Crop & 71 \\
\hline $\mathrm{C}$ & 1 & $\mathrm{C} 1$ & Grapefruit & Cantaloupes & 209 \\
\hline $\mathrm{C}$ & 2 & $\mathrm{C} 2$ & Lemons & Citrus & 72 \\
\hline $\mathrm{C}$ & 3 & C3 & Oranges & Oranges & 212 \\
\hline $\mathrm{C}$ & 4 & C4 & Dates & Other & 71 \\
\hline C & 5 & C5 & Avocados & Other & 71 \\
\hline C & 6 & $\mathrm{C} 6$ & Olives & Olives & 211 \\
\hline C & 7 & C7 & $\begin{array}{l}\text { Miscellaneous } \\
\text { subtropical fruits }\end{array}$ & Citrus & 72 \\
\hline $\mathrm{C}$ & 8 & C8 & Kiwis & Citrus & 72 \\
\hline$C$ & 9 & C9 & Jojoba & Other & 71 \\
\hline $\mathrm{C}$ & 10 & $\mathrm{C} 10$ & Eucalyptus & Other & 71 \\
\hline C & 99 & C99 & $\begin{array}{l}\text { Unknown citrus or } \\
\text { subtropical }\end{array}$ & Other & 71 \\
\hline $\mathrm{V}$ & 1 & V1 & Table Grapes & Grapes & 69 \\
\hline $\mathrm{V}$ & 2 & V2 & Wine Grapes & Grapes & 69 \\
\hline $\mathrm{V}$ & 3 & V3 & Raisin Grapes & Grapes & 69 \\
\hline $\mathrm{V}$ & 99 & V99 & Unknown grapes & Grapes & 69 \\
\hline
\end{tabular}

\begin{tabular}{|l|l|l|l|l|l|}
\hline $\begin{array}{l}\text { CLASS } \\
1\end{array}$ & $\begin{array}{l}\text { SUBCLASS } \\
1\end{array}$ & $\begin{array}{l}\text { Lookup } \\
\text { ID }\end{array}$ & DWR Description & NASS Description & $\begin{array}{l}\text { NASS ID } \\
\text { Value }\end{array}$ \\
\hline
\end{tabular}




\begin{tabular}{|c|c|c|c|c|c|}
\hline I & 1 & 11 & $\begin{array}{l}\text { Land not cropped } \\
\text { the current or } \\
\text { previous crop } \\
\text { season, but } \\
\text { cropped within the } \\
\text { past three years }\end{array}$ & Fallow/Idle cropland & 61 \\
\hline I & 2 & 12 & $\begin{array}{l}\text { New lands being } \\
\text { prepared for crop } \\
\text { production }\end{array}$ & Fallow/Idle cropland & 61 \\
\hline$S$ & 1 & $\mathrm{~s} 1$ & Farmsteads & Developed/Low Density & 122 \\
\hline $\mathrm{s}$ & 2 & S2 & Livestock feed lots & Developed/Low Density & 122 \\
\hline $\mathrm{s}$ & 3 & S3 & Dairies & Developed/Low Density & 122 \\
\hline $\mathrm{S}$ & 4 & $\mathrm{~S} 4$ & Poultry Farms & Developed/Low Density & 122 \\
\hline $\mathrm{U}$ & 1 & $\mathrm{U} 1$ & $\begin{array}{l}\text { generic } \\
\text { nomenclature with } \\
\text { no subclass }\end{array}$ & Developed/Low Density & 122 \\
\hline $\mathrm{U}$ & 99 & U99 & Urban & Developed/Low Density & 122 \\
\hline UR & 1 & UR1 & $\begin{array}{l}\text { Single family } \\
\text { dwelling with lot } \\
\text { sizes greater than } \\
1 \text { acre up to } 5 \\
\text { acres }\end{array}$ & Developed/Low Density & 122 \\
\hline UR & 11 & UR11 & $\begin{array}{l}\text { Single family } \\
\text { dwelling with lot } \\
\text { sizes greater than } \\
1 \text { acre up to } 5 \\
\text { acres - } 0 \%-25 \% \\
\text { area irrigated }\end{array}$ & Developed/Low Density & 122 \\
\hline UR & 12 & UR12 & $\begin{array}{l}\text { Single family } \\
\text { dwelling with lot } \\
\text { sizes greater than } \\
1 \text { acre up to } 5 \\
\text { acres - } 26 \%-50 \% \\
\text { area irrigated }\end{array}$ & Developed/Low Density & 122 \\
\hline UR & 13 & UR13 & $\begin{array}{l}\text { Single family } \\
\text { dwelling with lot } \\
\text { sizes greater than } \\
1 \text { acre up to } 5 \\
\text { acres - } 51 \%-75 \% \\
\text { area irrigated }\end{array}$ & Developed/Low Density & 122 \\
\hline UR & 14 & UR14 & $\begin{array}{l}\text { Single family } \\
\text { dwelling with lot } \\
\text { sizes greater than } \\
1 \text { acre up to } 5 \\
\text { acres }->76 \% \text { area } \\
\text { irrigated }\end{array}$ & Developed/Low Density & 122 \\
\hline UR & 2 & UR2 & $\begin{array}{l}\text { Single family } \\
\text { dwelling with a } \\
\text { density of } 1 \\
\text { unit/acre up to } 8+ \\
\text { units/acre }\end{array}$ & Developed/Med Density & 123 \\
\hline UR & 21 & UR21 & $\begin{array}{l}\text { Single family } \\
\text { dwelling with a } \\
\text { density of } 1 \\
\text { unit/acre up to } 8+ \\
\text { units/acre }-0 \%- \\
25 \% \text { area irrigated }\end{array}$ & Developed/Med Density & 123 \\
\hline $\begin{array}{l}\text { CLASS } \\
1\end{array}$ & SUBCLASS & $\begin{array}{l}\text { Lookup } \\
\text { ID }\end{array}$ & DWR Description & NASS Description & $\begin{array}{l}\text { NASS ID } \\
\text { Value }\end{array}$ \\
\hline
\end{tabular}




\begin{tabular}{|c|c|c|c|c|c|}
\hline UR & 22 & UR22 & $\begin{array}{l}\text { Single family } \\
\text { dwelling with a } \\
\text { density of } 1 \\
\text { unit/acre up to } 8+ \\
\text { units/acre }-26 \%- \\
50 \% \text { area irrigated }\end{array}$ & Developed/Med Density & 123 \\
\hline UR & 23 & UR23 & $\begin{array}{l}\text { Single family } \\
\text { dwelling with a } \\
\text { density of } 1 \\
\text { unit/acre up to } 8+ \\
\text { units/acre }-51 \% \text { - } \\
75 \% \text { area irrigated }\end{array}$ & Developed/Med Density & 123 \\
\hline UR & 24 & UR24 & $\begin{array}{l}\text { Single family } \\
\text { dwelling with a } \\
\text { density of } 1 \\
\text { unit/acre up to } 8+ \\
\text { units/acre }->76 \% \\
\text { area irrigated }\end{array}$ & Developed/Med Density & 123 \\
\hline UR & 3 & UR3 & $\begin{array}{l}\text { Multiple family } \\
\text { (apartments, } \\
\text { condos, } \\
\text { townhouses, etc.) }\end{array}$ & Developed/High Density & 124 \\
\hline UR & 31 & UR31 & $\begin{array}{l}\text { Multiple family } \\
\text { (apartments, } \\
\text { condos, } \\
\text { townhouses, etc.) - } \\
0 \%-25 \% \text { area } \\
\text { irrigated }\end{array}$ & Developed/High Density & 124 \\
\hline UR & 32 & UR32 & $\begin{array}{l}\text { Multiple family } \\
\text { (apartments, } \\
\text { condos, } \\
\text { townhouses, etc.) - } \\
26 \%-50 \% \text { area } \\
\text { irrigated }\end{array}$ & Developed/High Density & 124 \\
\hline UR & 33 & UR33 & $\begin{array}{l}\text { Multiple family } \\
\text { (apartments, } \\
\text { condos, } \\
\text { townhouses, etc.) - } \\
51 \%-75 \% \text { area } \\
\text { irrigated }\end{array}$ & Developed/High Density & 124 \\
\hline UR & 34 & UR34 & $\begin{array}{l}\text { Multiple family } \\
\text { (apartments, } \\
\text { condos, } \\
\text { townhouses, etc.) - } \\
>76 \% \text { area } \\
\text { irrigated }\end{array}$ & Developed/High Density & 124 \\
\hline UR & 4 & UR4 & Trailer courts & Developed/Med Density & 123 \\
\hline UR & 41 & UR41 & $\begin{array}{l}\text { Trailer courts }-0 \%- \\
25 \% \text { area irrigated }\end{array}$ & Developed/Med Density & 123 \\
\hline UR & 42 & UR42 & $\begin{array}{l}\text { Trailer courts - } \\
26 \%-50 \% \text { area } \\
\text { irrigated }\end{array}$ & Developed/Med Density & 123 \\
\hline UR & 43 & UR43 & $\begin{array}{l}\text { Trailer courts - } \\
51 \%-75 \% \text { area } \\
\text { irrigated }\end{array}$ & Developed/Med Density & 123 \\
\hline UR & 44 & UR44 & $\begin{array}{l}\text { Trailer courts - } \\
>76 \% \text { area } \\
\text { irrigated }\end{array}$ & Developed/Med Density & 123 \\
\hline $\begin{array}{l}\text { CLASS } \\
1 \\
\end{array}$ & $\begin{array}{l}\text { SUBCLASS } \\
1\end{array}$ & $\begin{array}{l}\text { Lookup } \\
\text { ID }\end{array}$ & DWR Description & NASS Description & $\begin{array}{l}\text { NASS ID } \\
\text { Value }\end{array}$ \\
\hline
\end{tabular}




\begin{tabular}{|c|c|c|c|c|c|}
\hline UR & 99 & UR99 & Residential & Developed/Med Density & 123 \\
\hline UC & 1 & UC1 & $\begin{array}{l}\text { Offices, retailer, } \\
\text { etc. }\end{array}$ & Developed/Med Density & 123 \\
\hline $\mathrm{UC}$ & 2 & UC2 & Hotels & Developed/High Density & 124 \\
\hline UC & 3 & UC3 & Motels & Developed/High Density & 124 \\
\hline UC & 4 & UC4 & $\begin{array}{l}\text { Recreation vehicle } \\
\text { parking, camp } \\
\text { sites }\end{array}$ & Developed/Open Space & 121 \\
\hline UC & 5 & UC5 & $\begin{array}{l}\text { Institutions } \\
\text { (hospitals, prisons, } \\
\text { reformatories, } \\
\text { asylums, etc.) }\end{array}$ & Developed/High Density & 124 \\
\hline UC & 6 & UC6 & Schools & Developed/High Density & 124 \\
\hline UC & 7 & UC7 & $\begin{array}{l}\text { Municipal } \\
\text { auditoriums, } \\
\text { theaters, churches, } \\
\text { buildings, etc }\end{array}$ & Developed/High Density & 124 \\
\hline UC & 8 & UC8 & $\begin{array}{l}\text { Miscellaneous high } \\
\text { water use }\end{array}$ & Developed/Open Space & 121 \\
\hline UI & 1 & UI1 & $\begin{array}{l}\text { Manufacturing, } \\
\text { assembly, and } \\
\text { general processing }\end{array}$ & Developed/High Density & 124 \\
\hline UI & 2 & $\mathrm{UI} 2$ & $\begin{array}{l}\text { Extractive } \\
\text { industries (oil } \\
\text { fields, rock } \\
\text { quarries, etc.) }\end{array}$ & Developed/High Density & 124 \\
\hline UI & 3 & UI3 & $\begin{array}{l}\text { Storage and } \\
\text { distribution } \\
\text { (warehouses, } \\
\text { substations, etc) }\end{array}$ & Developed/High Density & 124 \\
\hline $\mathrm{UI}$ & 6 & UI6 & Saw mills & Developed/High Density & 124 \\
\hline $\mathrm{UI}$ & 7 & UI7 & Oil refineries & Developed/High Density & 124 \\
\hline $\mathrm{UI}$ & 8 & UI8 & paper mills & Developed/High Density & 124 \\
\hline UI & 9 & UI9 & $\begin{array}{l}\text { Meat packing } \\
\text { plants }\end{array}$ & Developed/High Density & 124 \\
\hline UI & 10 & Ul10 & $\begin{array}{l}\text { steel and } \\
\text { aluminum mills }\end{array}$ & Developed/High Density & 124 \\
\hline $\mathrm{UI}$ & 11 & UI11 & $\begin{array}{l}\text { Fruit and } \\
\text { vegetable } \\
\text { canneries and } \\
\text { general food } \\
\text { processing }\end{array}$ & Developed/High Density & 124 \\
\hline $\mathrm{UI}$ & 12 & UI12 & $\begin{array}{l}\text { Miscellaneous high } \\
\text { water use }\end{array}$ & Developed/Open Space & 121 \\
\hline UI & 13 & UI13 & $\begin{array}{l}\text { Sewage treatment } \\
\text { plant including } \\
\text { ponds }\end{array}$ & Developed/Open Space & 121 \\
\hline $\mathrm{UI}$ & 14 & Ul14 & $\begin{array}{l}\text { Waste } \\
\text { accumulation sites }\end{array}$ & Developed/Open Space & 121 \\
\hline UI & 15 & Ul15 & $\begin{array}{l}\text { Wind farms, solar } \\
\text { collector farms }\end{array}$ & Developed/Low Density & 122 \\
\hline UL & 1 & UL1 & $\begin{array}{l}\text { Lawn area - } \\
\text { irrigated }\end{array}$ & Sod/Grass Seed & 59 \\
\hline UL & 2 & UL2 & $\begin{array}{l}\text { Golf course - } \\
\text { irrigated }\end{array}$ & Sod/Grass Seed & 59 \\
\hline
\end{tabular}

\begin{tabular}{|c|c|c|c|c|c|}
\hline \begin{tabular}{|l|} 
CLASS \\
1 \\
\end{tabular} & \begin{tabular}{|l|} 
SUBCLASS \\
1
\end{tabular} & $\begin{array}{l}\text { Lookup } \\
\text { ID }\end{array}$ & DWR Description & NASS Description & $\begin{array}{l}\text { NASS ID } \\
\text { Value }\end{array}$ \\
\hline
\end{tabular}




\begin{tabular}{|c|c|c|c|c|c|}
\hline UL & 3 & UL3 & $\begin{array}{l}\text { Ornamental } \\
\text { landscape } \\
\text { (excluding lawns) - } \\
\text { irrigated }\end{array}$ & Sod/Grass Seed & 59 \\
\hline UL & 4 & UL4 & $\begin{array}{l}\text { Cemeteries - } \\
\text { irrigated }\end{array}$ & Sod/Grass Seed & 59 \\
\hline UL & 5 & UL5 & $\begin{array}{l}\text { Cemeteries - not } \\
\text { irrigated }\end{array}$ & Non ag/Undefined & 88 \\
\hline UV & 1 & UV1 & Unpaved areas & Barren & 65 \\
\hline UV & 3 & UV3 & Railroad right of way & Developed/Low Density & 122 \\
\hline UV & 4 & UV4 & Paved areas & Developed/High Density & 124 \\
\hline UV & 6 & UV6 & Airport runways & Developed/High Density & 124 \\
\hline UV & 99 & UV99 & Vacant & Developed/High Density & 124 \\
\hline NC & 1 & NC1 & $\begin{array}{l}\text { Native Classes } \\
\text { Unsegregated }\end{array}$ & Grassland Herbaceous & 171 \\
\hline NV & 1 & NV1 & Grass land & Grassland Herbaceous & 171 \\
\hline NV & 2 & NV2 & Light brush & Shrubland & 152 \\
\hline NV & 3 & NV3 & Medium brush & Shrubland & 152 \\
\hline NV & 4 & NV4 & Heavy Brush & Shrubland & 152 \\
\hline NV & 5 & NV5 & Brush and timber & Mixed Forest & 143 \\
\hline NV & 6 & NV6 & Forest & Mixed Forest & 143 \\
\hline NV & 7 & NV7 & Oak woodland & Deciduous Forest & 141 \\
\hline NV & 99 & NV99 & Native Vegetation & Mixed Forest & 143 \\
\hline NR & 1 & NR1 & $\begin{array}{l}\text { Marsh Lands, tules, } \\
\text { and sedges }\end{array}$ & Herbaceous Wetlands & 195 \\
\hline NR & 2 & NR2 & $\begin{array}{l}\text { Natural high water } \\
\text { table meadow }\end{array}$ & Herbaceous Wetlands & 195 \\
\hline NR & 3 & NR3 & $\begin{array}{l}\text { Trees, shrubs or } \\
\text { other larger streams } \\
\text { side or watercourse } \\
\text { vegetation }\end{array}$ & Woody Wetlands & 190 \\
\hline NR & 4 & NR4 & $\begin{array}{l}\text { Seasonal duck } \\
\text { marsh, dry or only } \\
\text { partially wet during } \\
\text { summer }\end{array}$ & Herbaceous Wetlands & 195 \\
\hline NR & 5 & NR5 & $\begin{array}{l}\text { Permanent duck } \\
\text { marsh, flooded } \\
\text { during summer }\end{array}$ & Herbaceous Wetlands & 195 \\
\hline & & NR99 & Riparian Vegetation & Herbaceous Wetlands & 196 \\
\hline NW & 1 & NW1 & $\begin{array}{l}\text { Lakes, Reservoirs, } \\
\text { rivers, canals, etc }\end{array}$ & Open Water & 111 \\
\hline NW & 99 & NW99 & Water Surface & Open Water & 111 \\
\hline NB & 1 & NB1 & $\begin{array}{l}\text { Dry streams } \\
\text { channels }\end{array}$ & Open Water & 111 \\
\hline NB & 2 & NB2 & Mine tailings & Barren & 131 \\
\hline NB & 3 & NB3 & Barren land & Barren & 131 \\
\hline NB & 4 & NB4 & Salt flats & Barren & 131 \\
\hline NB & 5 & NB5 & Sand dunes & Barren & 131 \\
\hline NB & 99 & NB99 & Riparian Vegetation & Barren & 131 \\
\hline NS & 1 & NS1 & Not surveyed & Barren & 131 \\
\hline $\mathrm{E}$ & 1 & $\mathrm{E} 1$ & Entry denied & Barren & 131 \\
\hline Z & 1 & Z1 & $\begin{array}{l}\text { Outside area of } \\
\text { study }\end{array}$ & Background & 0 \\
\hline z & 99 & Z99 & $\begin{array}{l}\text { Outside area of } \\
\text { study }\end{array}$ & Background & 0 \\
\hline
\end{tabular}




\section{Appendix B. Merced 2002 DWR to NASS ID conversion}

\begin{tabular}{|c|c|c|c|c|c|}
\hline $\begin{array}{l}\text { CLASS } \\
1\end{array}$ & SUBCLASS1 & $\begin{array}{l}\text { Lookup } \\
\text { ID }\end{array}$ & DWR Description & NASS Description & $\begin{array}{l}\text { NASS ID } \\
\text { Value }\end{array}$ \\
\hline G & 1 & G1 & Barley & Barley & 21 \\
\hline G & 2 & G2 & Wheat & Spring Wheat & 23 \\
\hline G & 3 & G3 & Oats & Oats & 28 \\
\hline G & 6 & G6 & $\begin{array}{l}\text { Misc and mixed grain } \\
\text { and hay }\end{array}$ & Other Hay/Non Alfalfa & 37 \\
\hline G & 99 & G99 & $\begin{array}{l}\text { Unknown mixed grain } \\
\text { and hay }\end{array}$ & Other Hay/ Non Alfalfa & 37 \\
\hline $\mathrm{R}$ & 1 & $\mathrm{R} 1$ & Rice & Rice & 3 \\
\hline $\mathrm{R}$ & 99 & R99 & Unknown Rice & Rice & \\
\hline $\mathrm{F}$ & 1 & F1 & Cotton & Cotton & 2 \\
\hline $\mathrm{F}$ & 2 & $\mathrm{~F} 2$ & Safflower & Safflower & 33 \\
\hline $\mathrm{F}$ & 3 & F3 & Flax & Flaxseed & 32 \\
\hline $\mathrm{F}$ & 4 & $\mathrm{~F} 4$ & Hops & Hops & 56 \\
\hline $\mathrm{F}$ & 5 & F5 & Sugar Beets & Sugar beets & 41 \\
\hline $\mathrm{F}$ & 6 & F6 & Corn (field and sweet) & Corn & 12 \\
\hline $\mathrm{F}$ & 7 & $\mathrm{~F} 7$ & Grain sorghum & Sorghum & 4 \\
\hline $\mathrm{F}$ & 8 & F8 & Sudan & Sorghum & 4 \\
\hline $\mathrm{F}$ & 9 & F9 & Castor Beans & Dry Beans & 42 \\
\hline $\mathrm{F}$ & 10 & F10 & Beans (dry) & Dry Beans & 42 \\
\hline $\mathrm{F}$ & 11 & F11 & Miscellaneous field & Pasture/Grass & 62 \\
\hline $\mathrm{F}$ & 12 & $\mathrm{~F} 12$ & Sunflowers & Sunflower & 6 \\
\hline $\mathrm{F}$ & 99 & F99 & Unknown Field Crop & Safflower & 33 \\
\hline $\mathrm{P}$ & 1 & $\mathrm{P} 1$ & Alfalfa \& alfalfa mixtures & Alfalfa & 36 \\
\hline $\mathrm{P}$ & 2 & $\mathrm{P} 2$ & Clover & Clover/Wildflower & 58 \\
\hline $\mathrm{P}$ & 3 & P3 & Mixed pasture & Pasture/Grass & 62 \\
\hline$P$ & 4 & $\mathrm{P} 4$ & Native Pasture & Pasture/Grass & 62 \\
\hline$P$ & 5 & P5 & $\begin{array}{l}\text { Induced high water table } \\
\text { native pasture }\end{array}$ & Pasture/Grass & 62 \\
\hline $\mathrm{P}$ & 6 & P6 & $\begin{array}{l}\text { Misc. grasses (normally } \\
\text { grown from seed) }\end{array}$ & Pasture/Grass & 62 \\
\hline $\mathrm{P}$ & 7 & $\mathrm{P} 7$ & Turf farm & Sod/Grass Seed & 59 \\
\hline $\mathrm{P}$ & 99 & P99 & Unknown Pasture & Pasture/Grass & 62 \\
\hline $\mathrm{T}$ & 1 & $\mathrm{~T} 1$ & Artichokes & Asparagus & 207 \\
\hline $\mathrm{T}$ & 2 & $\mathrm{~T} 2$ & Asparagus & Asparagus & 207 \\
\hline $\mathrm{T}$ & 3 & T3 & Beans (green) & Dry Beans & 42 \\
\hline
\end{tabular}




\begin{tabular}{|c|c|c|c|c|c|}
\hline $\mathrm{T}$ & 4 & T4 & $\begin{array}{l}\text { Cole crop (when further } \\
\text { breakdown is not } \\
\text { needed) }\end{array}$ & Pasture/Grass & 62 \\
\hline $\mathrm{T}$ & 5 & T5 & Unknown & Misc. Vegs \& Fruits & 47 \\
\hline $\mathrm{T}$ & 6 & T6 & Carrots & Carrots & 206 \\
\hline $\mathrm{T}$ & 7 & $\mathrm{T7}$ & Celery & Celery & 245 \\
\hline $\mathrm{T}$ & 8 & T8 & Lettuce (all types) & Lettuce & 227 \\
\hline $\mathrm{T}$ & 9 & T9 & $\begin{array}{l}\text { Melons, squash, and } \\
\text { cucumbers (all types) }\end{array}$ & Watermelons & 48 \\
\hline $\mathrm{T}$ & 10 & $\mathrm{~T} 10$ & Onions and garlic & Onions & 49 \\
\hline $\mathrm{T}$ & 11 & $\mathrm{~T} 11$ & Peas & Peas & 53 \\
\hline $\mathrm{T}$ & 12 & $\mathrm{~T} 12$ & Potatoes & Potatoes & 43 \\
\hline $\mathrm{T}$ & 13 & $\mathrm{~T} 13$ & Sweet Potatoes & Sweet Potatoes & 46 \\
\hline $\mathrm{T}$ & 14 & $\mathrm{~T} 14$ & Spinach & Greens & 219 \\
\hline $\mathrm{T}$ & 15 & $\mathrm{~T} 15$ & Tomatoes & Tomatoes & 54 \\
\hline $\mathrm{T}$ & 16 & $\mathrm{~T} 16$ & $\begin{array}{l}\text { Flowers, nursery \& } \\
\text { Christmas tree farms }\end{array}$ & Christmas Trees & 70 \\
\hline $\mathrm{T}$ & 17 & T17 & Mixed (four or more) & Misc. Vegs \& Fruits & 47 \\
\hline $\mathrm{T}$ & 18 & T18 & Miscellaneous truck & Misc. Vegs \& Fruits & 47 \\
\hline $\bar{T}$ & 19 & T19 & Bush berries & Blueberries & 242 \\
\hline $\mathrm{T}$ & 20 & T20 & Strawberries & Strawberries & 221 \\
\hline $\mathrm{T}$ & 21 & $\mathrm{~T} 21$ & Peppers (chili, bell, etc.) & Peppers & 216 \\
\hline $\mathrm{T}$ & 22 & T22 & Broccoli & Broccoli & 214 \\
\hline $\mathrm{T}$ & 23 & $\mathrm{~T} 23$ & Cabbage & Cabbage & 243 \\
\hline $\mathrm{T}$ & 24 & $\mathrm{~T} 24$ & Cauliflower & Cauliflower & 244 \\
\hline $\mathrm{T}$ & 25 & $\mathrm{~T} 25$ & Brussels Sprouts & Asparagus & 207 \\
\hline $\mathrm{T}$ & 99 & T99 & $\begin{array}{l}\text { Unknown truck, nursery, } \\
\text { and berry crops }\end{array}$ & Misc. Vegs \& Fruits & 47 \\
\hline $\mathrm{D}$ & 1 & D1 & Apples & Apples & 68 \\
\hline $\mathrm{D}$ & 2 & D2 & Apricots & Apricots & 223 \\
\hline $\mathrm{D}$ & 3 & D3 & Cherries & Cherries & 66 \\
\hline $\mathrm{D}$ & 5 & D5 & Peaches and nectarines & Peaches & 67 \\
\hline $\mathrm{D}$ & 6 & D6 & Pears & Pears & 77 \\
\hline $\mathrm{D}$ & 7 & D7 & Plums & Plums & 220 \\
\hline $\mathrm{D}$ & 8 & D8 & Prunes & Prunes & 210 \\
\hline $\mathrm{D}$ & 9 & D9 & Figs & Other Tree crop & 71 \\
\hline $\mathrm{D}$ & 10 & D10 & Miscellaneous deciduous & Deciduous Forest & 141 \\
\hline $\mathrm{D}$ & 12 & D12 & Almonds & Almond & 75 \\
\hline D & 13 & D13 & Walnuts & Walnuts & 76 \\
\hline
\end{tabular}




\begin{tabular}{|c|c|c|c|c|c|}
\hline$D$ & 14 & D14 & Pistachios & Pistachios & 204 \\
\hline D & 99 & D99 & Unknown tree crop & Other Tree Crop & 71 \\
\hline C & 1 & $\mathrm{C} 1$ & Grapefruit & Cantaloupes & 209 \\
\hline C & 2 & $\mathrm{C} 2$ & Lemons & Citrus & 72 \\
\hline C & 3 & C3 & Oranges & Oranges & 212 \\
\hline C & 4 & $\mathrm{C} 4$ & Dates & Other & 71 \\
\hline C & 5 & C5 & Avocados & Other & 71 \\
\hline C & 6 & C6 & Olives & Olives & 211 \\
\hline C & 7 & $\mathrm{C} 7$ & $\begin{array}{l}\text { Miscellaneous } \\
\text { subtropical fruits }\end{array}$ & Citrus & 72 \\
\hline C & 8 & $\mathrm{C} 8$ & Kiwis & Citrus & 72 \\
\hline C & 9 & $\mathrm{C9}$ & Jojoba & Other & 71 \\
\hline C & 10 & C10 & Eucalyptus & Other & 71 \\
\hline C & 99 & C99 & $\begin{array}{l}\text { Unknown citrus or } \\
\text { subtropical }\end{array}$ & Other & 71 \\
\hline V & 1 & $\mathrm{~V} 1$ & Table Grapes & Grapes & 69 \\
\hline $\mathrm{V}$ & 2 & V2 & Wine Grapes & Grapes & 69 \\
\hline V & 3 & V3 & Raisin Grapes & Grapes & 69 \\
\hline V & 99 & V99 & Unknown grapes & Grapes & 69 \\
\hline I & 1 & 11 & $\begin{array}{l}\text { Land not cropped the } \\
\text { current or previous crop } \\
\text { season, but cropped } \\
\text { within the past three } \\
\text { years }\end{array}$ & Fallow/ldle cropland & 61 \\
\hline 1 & 2 & 12 & $\begin{array}{l}\text { New lands being } \\
\text { prepared for crop } \\
\text { production }\end{array}$ & Fallow/ldle cropland & 61 \\
\hline S & 1 & S1 & Farmsteads & $\begin{array}{l}\text { Developed/Low } \\
\text { Density }\end{array}$ & 122 \\
\hline S & 2 & S2 & Livestock feed lots & $\begin{array}{l}\text { Developed/Low } \\
\text { Density }\end{array}$ & 122 \\
\hline$S$ & 3 & S3 & Dairies & $\begin{array}{l}\text { Developed/Low } \\
\text { Density }\end{array}$ & 122 \\
\hline S & 4 & S4 & Poultry Farms & $\begin{array}{l}\text { Developed/Low } \\
\text { Density }\end{array}$ & 122 \\
\hline U & 1 & U1 & $\begin{array}{l}\text { generic nomenclature } \\
\text { with no subclass }\end{array}$ & $\begin{array}{l}\text { Developed/Low } \\
\text { Density }\end{array}$ & 122 \\
\hline$U$ & 99 & U99 & Urban & $\begin{array}{l}\text { Developed/Low } \\
\text { Density }\end{array}$ & 122 \\
\hline UR & 1 & UR1 & $\begin{array}{l}\text { Single family dwelling } \\
\text { with lot sizes greater } \\
\text { than } 1 \text { acre up to } 5 \text { acres }\end{array}$ & $\begin{array}{l}\text { Developed/Low } \\
\text { Density }\end{array}$ & 122 \\
\hline UR & 11 & UR11 & $\begin{array}{l}\text { Single family dwelling } \\
\text { with lot sizes greater }\end{array}$ & $\begin{array}{l}\text { Developed/Low } \\
\text { Density }\end{array}$ & 122 \\
\hline
\end{tabular}




\begin{tabular}{|c|c|c|c|c|c|}
\hline & & & $\begin{array}{l}\text { than } 1 \text { acre up to } 5 \text { acres } \\
-0 \%-25 \% \text { area irrigated }\end{array}$ & & \\
\hline UR & 12 & UR12 & $\begin{array}{l}\text { Single family dwelling } \\
\text { with lot sizes greater } \\
\text { than } 1 \text { acre up to } 5 \text { acres } \\
-26 \%-50 \% \text { area irrigated }\end{array}$ & $\begin{array}{l}\text { Developed/Low } \\
\text { Density }\end{array}$ & 122 \\
\hline UR & 13 & UR13 & $\begin{array}{l}\text { Single family dwelling } \\
\text { with lot sizes greater } \\
\text { than } 1 \text { acre up to } 5 \text { acres } \\
-51 \%-75 \% \text { area irrigated }\end{array}$ & $\begin{array}{l}\text { Developed/Low } \\
\text { Density }\end{array}$ & 122 \\
\hline UR & 14 & UR14 & $\begin{array}{l}\text { Single family dwelling } \\
\text { with lot sizes greater } \\
\text { than } 1 \text { acre up to } 5 \text { acres } \\
->76 \% \text { area irrigated }\end{array}$ & $\begin{array}{l}\text { Developed/Low } \\
\text { Density }\end{array}$ & 122 \\
\hline UR & 2 & UR2 & $\begin{array}{l}\text { Single family dwelling } \\
\text { with a density of } 1 \\
\text { unit/acre up to } 8+ \\
\text { units/acre }\end{array}$ & $\begin{array}{l}\text { Developed/Med } \\
\text { Density }\end{array}$ & 123 \\
\hline UR & 21 & UR21 & $\begin{array}{l}\text { Single family dwelling } \\
\text { with a density of } 1 \\
\text { unit/acre up to } 8+ \\
\text { units/acre }-0 \%-25 \% \text { area } \\
\text { irrigated }\end{array}$ & $\begin{array}{l}\text { Developed/Med } \\
\text { Density }\end{array}$ & 123 \\
\hline UR & 22 & UR22 & $\begin{array}{l}\text { Single family dwelling } \\
\text { with a density of } 1 \\
\text { unit/acre up to } 8+ \\
\text { units/acre }-26 \%-50 \% \\
\text { area irrigated }\end{array}$ & $\begin{array}{l}\text { Developed/Med } \\
\text { Density }\end{array}$ & 123 \\
\hline UR & 23 & UR23 & $\begin{array}{l}\text { Single family dwelling } \\
\text { with a density of } 1 \\
\text { unit/acre up to } 8+ \\
\text { units/acre }-51 \%-75 \% \\
\text { area irrigated }\end{array}$ & $\begin{array}{l}\text { Developed/Med } \\
\text { Density }\end{array}$ & 123 \\
\hline UR & 24 & UR24 & $\begin{array}{l}\text { Single family dwelling } \\
\text { with a density of } 1 \\
\text { unit/acre up to } 8+ \\
\text { units/acre - }>76 \% \text { area } \\
\text { irrigated }\end{array}$ & $\begin{array}{l}\text { Developed/Med } \\
\text { Density }\end{array}$ & 123 \\
\hline UR & 3 & UR3 & $\begin{array}{l}\text { Multiple family } \\
\text { (apartments, condos, } \\
\text { townhouses, etc.) }\end{array}$ & $\begin{array}{l}\text { Developed/High } \\
\text { Density }\end{array}$ & 124 \\
\hline UR & 31 & UR31 & $\begin{array}{l}\text { Multiple family } \\
\text { (apartments, condos, } \\
\text { townhouses, etc.) - 0\%- } \\
25 \% \text { area irrigated }\end{array}$ & $\begin{array}{l}\text { Developed/High } \\
\text { Density }\end{array}$ & 124 \\
\hline UR & 32 & UR32 & $\begin{array}{l}\text { Multiple family } \\
\text { (apartments, condos, } \\
\text { townhouses, etc.) - } 26 \% \text { - } \\
50 \% \text { area irrigated }\end{array}$ & $\begin{array}{l}\text { Developed/High } \\
\text { Density }\end{array}$ & 124 \\
\hline UR & 33 & UR33 & $\begin{array}{l}\text { Multiple family } \\
\text { (apartments, condos, } \\
\text { townhouses, etc.) - } 51 \%- \\
75 \% \text { area irrigated }\end{array}$ & $\begin{array}{l}\text { Developed/High } \\
\text { Density }\end{array}$ & 124 \\
\hline
\end{tabular}




\begin{tabular}{|c|c|c|c|c|c|}
\hline UR & 34 & UR34 & $\begin{array}{l}\text { Multiple family } \\
\text { (apartments, condos, } \\
\text { townhouses, etc.) - } \\
>76 \% \text { area irrigated }\end{array}$ & $\begin{array}{l}\text { Developed/High } \\
\text { Density }\end{array}$ & 124 \\
\hline UR & 4 & UR4 & Trailer courts & $\begin{array}{l}\text { Developed/Med } \\
\text { Density }\end{array}$ & 123 \\
\hline UR & 41 & UR41 & $\begin{array}{l}\text { Trailer courts - } 0 \%-25 \% \\
\text { area irrigated }\end{array}$ & $\begin{array}{l}\text { Developed/Med } \\
\text { Density }\end{array}$ & 123 \\
\hline UR & 42 & UR42 & $\begin{array}{l}\text { Trailer courts - } 26 \%-50 \% \\
\text { area irrigated }\end{array}$ & $\begin{array}{l}\text { Developed/Med } \\
\text { Density }\end{array}$ & 123 \\
\hline UR & 43 & UR43 & $\begin{array}{l}\text { Trailer courts - } 51 \%-75 \% \\
\text { area irrigated }\end{array}$ & $\begin{array}{l}\text { Developed/Med } \\
\text { Density }\end{array}$ & 123 \\
\hline UR & 44 & UR44 & $\begin{array}{l}\text { Trailer courts - > } 76 \% \\
\text { area irrigated }\end{array}$ & $\begin{array}{l}\text { Developed/Med } \\
\text { Density }\end{array}$ & 123 \\
\hline UR & 99 & UR99 & Residential & $\begin{array}{l}\text { Developed/Med } \\
\text { Density }\end{array}$ & 123 \\
\hline UC & 1 & UC1 & Offices, retailer, etc. & $\begin{array}{l}\text { Developed/Med } \\
\text { Density }\end{array}$ & 123 \\
\hline UC & 2 & UC2 & Hotels & $\begin{array}{l}\text { Developed/High } \\
\text { Density }\end{array}$ & 124 \\
\hline UC & 3 & UC3 & Motels & $\begin{array}{l}\text { Developed/High } \\
\text { Density }\end{array}$ & 124 \\
\hline UC & 4 & UC4 & $\begin{array}{l}\text { Recreation vehicle } \\
\text { parking, camp sites }\end{array}$ & $\begin{array}{l}\text { Developed/Open } \\
\text { Space }\end{array}$ & 121 \\
\hline UC & 5 & UC5 & $\begin{array}{l}\text { Institutions (hospitals, } \\
\text { prisons, reformatories, } \\
\text { asylums, etc.) }\end{array}$ & $\begin{array}{l}\text { Developed/High } \\
\text { Density }\end{array}$ & 124 \\
\hline UC & 6 & UC6 & Schools & $\begin{array}{l}\text { Developed/High } \\
\text { Density }\end{array}$ & 124 \\
\hline UC & 7 & UC7 & $\begin{array}{l}\text { Municipal auditoriums, } \\
\text { theaters, churches, } \\
\text { buildings, etc }\end{array}$ & $\begin{array}{l}\text { Developed/High } \\
\text { Density }\end{array}$ & 124 \\
\hline UC & 8 & UC8 & $\begin{array}{l}\text { Miscellaneous high water } \\
\text { use }\end{array}$ & $\begin{array}{l}\text { Developed/Open } \\
\text { Space }\end{array}$ & 121 \\
\hline UC & 99 & UC99 & $\begin{array}{l}\text { Unknown } \\
\text { Developed/Open Space }\end{array}$ & $\begin{array}{l}\text { Developed/Open } \\
\text { Space }\end{array}$ & 121 \\
\hline UI & 1 & Ul1 & $\begin{array}{l}\text { Manufacturing, } \\
\text { assembly, and general } \\
\text { processing }\end{array}$ & $\begin{array}{l}\text { Developed/High } \\
\text { Density }\end{array}$ & 124 \\
\hline UI & 2 & UI2 & $\begin{array}{l}\text { Extractive industries (oil } \\
\text { fields, rock quarries, etc.) }\end{array}$ & $\begin{array}{l}\text { Developed/High } \\
\text { Density }\end{array}$ & 124 \\
\hline UI & 3 & UI3 & $\begin{array}{l}\text { Storage and distribution } \\
\text { (warehouses, } \\
\text { substations, etc) }\end{array}$ & $\begin{array}{l}\text { Developed/High } \\
\text { Density }\end{array}$ & 124 \\
\hline UI & 6 & UI6 & Saw mills & $\begin{array}{l}\text { Developed/High } \\
\text { Density }\end{array}$ & 124 \\
\hline
\end{tabular}




\begin{tabular}{|c|c|c|c|c|c|}
\hline UI & 7 & UI7 & Oil refineries & $\begin{array}{l}\text { Developed/High } \\
\text { Density }\end{array}$ & 124 \\
\hline UI & 8 & UI8 & paper mills & $\begin{array}{l}\text { Developed/High } \\
\text { Density }\end{array}$ & 124 \\
\hline UI & 9 & UI9 & Meat packing plants & $\begin{array}{l}\text { Developed/High } \\
\text { Density }\end{array}$ & 124 \\
\hline UI & 10 & Ul10 & steel and aluminum mills & $\begin{array}{l}\text { Developed/High } \\
\text { Density }\end{array}$ & 124 \\
\hline UI & 11 & Ul11 & $\begin{array}{l}\text { Fruit and vegetable } \\
\text { canneries and general } \\
\text { food processing }\end{array}$ & $\begin{array}{l}\text { Developed/High } \\
\text { Density }\end{array}$ & 124 \\
\hline $\mathrm{UI}$ & 12 & Ul12 & $\begin{array}{l}\text { Miscellaneous high water } \\
\text { use }\end{array}$ & $\begin{array}{l}\text { Developed/Open } \\
\text { Space }\end{array}$ & 121 \\
\hline UI & 13 & Ul13 & $\begin{array}{l}\text { Sewage treatment plant } \\
\text { including ponds }\end{array}$ & $\begin{array}{l}\text { Developed/Open } \\
\text { Space }\end{array}$ & 121 \\
\hline $\mathrm{UI}$ & 14 & Ul14 & Wast accumulation sites & $\begin{array}{l}\text { Developed/Open } \\
\text { Space }\end{array}$ & 121 \\
\hline UI & 15 & Ul15 & $\begin{array}{l}\text { Wind farms, solar } \\
\text { collector farms }\end{array}$ & $\begin{array}{l}\text { Developed/Low } \\
\text { Density }\end{array}$ & 122 \\
\hline UI & 99 & U199 & $\begin{array}{l}\text { Unknown } \\
\text { Develped/Open Space }\end{array}$ & $\begin{array}{l}\text { Developed/Low } \\
\text { Density }\end{array}$ & 122 \\
\hline UL & 1 & UL1 & Lawn area - irrigated & Sod/Grass Seed & 59 \\
\hline UL & 2 & UL2 & Golf course - irrigated & Sod/Grass Seed & 59 \\
\hline UL & 3 & UL3 & $\begin{array}{l}\text { Ornamental landscape } \\
\text { (excluding lawns) - } \\
\text { irrigated }\end{array}$ & Sod/Grass Seed & 59 \\
\hline UL & 4 & UL4 & Cemeteries - irrigated & Sod/Grass Seed & 59 \\
\hline UL & 5 & UL5 & Cemeteries - not irrigated & Nonag/Undefined & 88 \\
\hline UL & 99 & UL99 & Unknown non-crop & Nonag/Undefined & 88 \\
\hline UV & 1 & UV1 & Unpaved areas & Barren & 65 \\
\hline UV & 3 & UV3 & Railroad right of way & $\begin{array}{l}\text { Developed/Low } \\
\text { Density }\end{array}$ & 122 \\
\hline UV & 4 & UV4 & Paved areas & $\begin{array}{l}\text { Developed/High } \\
\text { Density }\end{array}$ & 124 \\
\hline UV & 6 & UV6 & Airport runways & $\begin{array}{l}\text { Developed/High } \\
\text { Density }\end{array}$ & 124 \\
\hline UV & 99 & UV99 & Vacant & $\begin{array}{l}\text { Developed/High } \\
\text { Density }\end{array}$ & 124 \\
\hline NC & 1 & NC1 & $\begin{array}{l}\text { Native Classes } \\
\text { Unsegregated }\end{array}$ & Grassland Herbaceous & 171 \\
\hline NV & 1 & NV1 & Grass land & Grassland Herbaceous & 171 \\
\hline NV & 2 & NV2 & Light brush & Shrubland & 152 \\
\hline NV & 3 & NV3 & Medium brush & Shrubland & 152 \\
\hline NV & 4 & NV4 & Heavy Brush & Shrubland & 152 \\
\hline
\end{tabular}




\begin{tabular}{|c|c|c|c|c|c|}
\hline NV & 5 & NV5 & Brush and timber & Mixed Forest & 143 \\
\hline NV & 6 & NV6 & Forest & Mixed Forest & 143 \\
\hline NV & 7 & NV7 & Oak woodland & Deciduous Forest & 141 \\
\hline NV & 99 & NV99 & Native Vegetation & Mixed Forest & 143 \\
\hline NR & 1 & NR1 & $\begin{array}{l}\text { Marsh Lands, tules, and } \\
\text { sedges }\end{array}$ & Herbaceous Wetlands & 195 \\
\hline NR & 2 & NR2 & $\begin{array}{l}\text { Natural high water table } \\
\text { meadow }\end{array}$ & Herbaceous Wetlands & 195 \\
\hline NR & 3 & NR3 & $\begin{array}{l}\text { Trees, shrubs or other } \\
\text { larger streams side or } \\
\text { watercourse vegetation }\end{array}$ & Woody Wetlands & 190 \\
\hline NR & 4 & NR4 & $\begin{array}{l}\text { Seasonal duck marsh, } \\
\text { dry or only partially wet } \\
\text { during summer }\end{array}$ & Herbaceous Wetlands & 195 \\
\hline NR & 5 & NR5 & $\begin{array}{l}\text { Permanent duck marsh, } \\
\text { flooded during summer }\end{array}$ & Herbaceous Wetlands & 195 \\
\hline & & NR99 & Riparian Vegetation & Herbaceous Wetlands & 196 \\
\hline NW & 1 & NW1 & $\begin{array}{l}\text { Lakes, Reservoirs, rivers, } \\
\text { canals, etc }\end{array}$ & Open Water & 111 \\
\hline NW & 99 & NW99 & Water Surface & Open Water & 111 \\
\hline NB & 1 & NB1 & Dry streams channels & Open Water & 111 \\
\hline NB & 2 & NB2 & Mine tailings & Barren & 131 \\
\hline NB & 3 & NB3 & Barren land & Barren & 131 \\
\hline NB & 4 & NB4 & Salt flats & Barren & 131 \\
\hline NB & 5 & NB5 & Sand dunes & Barren & 131 \\
\hline NB & 99 & NB99 & Riparian Vegetation & Barren & 131 \\
\hline NS & 1 & NS1 & Not surveyed & Barren & 131 \\
\hline$E$ & 1 & E1 & Entry denied & Barren & 131 \\
\hline Z & 1 & Z1 & Outside area of study & Background & 0 \\
\hline Z & 99 & Z99 & Outside area of study & Background & 0 \\
\hline
\end{tabular}


Appendix C. Full list of NASS ID and Classifier descriptions

\begin{tabular}{|c|c|c|c|}
\hline $\begin{array}{l}\text { NASS ID } \\
\text { Value }\end{array}$ & Class Name & $\begin{array}{l}\text { NASS ID } \\
\text { Value }\end{array}$ & Class Name \\
\hline 0 & Background & 81 & Clouds/No Data \\
\hline 1 & Corn & 82 & Developed \\
\hline 2 & Cotton & 83 & Water \\
\hline 3 & Rice & 87 & Wetlands \\
\hline 4 & Sorghum & 88 & Non ag/Undefined \\
\hline 5 & Soybeans & 92 & Aquaculture \\
\hline 6 & Sunflower & 111 & Open Water \\
\hline 10 & Peanuts & 112 & Perennial Ice/Snow \\
\hline 11 & Tobacco & 121 & Developed/Open Space \\
\hline 12 & Corn & 122 & Developed/Low Intensity \\
\hline 13 & Pop or Orn Corn & 123 & Developed/Med Intensity \\
\hline 14 & Mint & 124 & Developed/High Intensity \\
\hline 21 & Barley & 131 & Barren \\
\hline 22 & Durum Wheat & 141 & Deciduous Forest \\
\hline 23 & Spring Wheat & 142 & Evergreen Forest \\
\hline 24 & Winter Wheat & 143 & Mixed Forest \\
\hline 25 & Other Small Grains & 152 & Shrubland \\
\hline 26 & $\begin{array}{l}\text { Dbl Crop } \\
\text { WinWht/Soybeans }\end{array}$ & 171 & Grassland Herbaceous \\
\hline 27 & Rye & 181 & Pasture/Hay \\
\hline 28 & Oats & 190 & Woody Wetlands \\
\hline 29 & Millet & 195 & Herbaceous Wetlands \\
\hline 30 & Speltz & 204 & Pistachios \\
\hline 31 & Canola & 205 & Triticale \\
\hline 32 & Flaxseed & 206 & Carrots \\
\hline 33 & Safflower & 207 & Asparagus \\
\hline 34 & Rape Seed & 208 & Garlic \\
\hline 35 & Mustard & 209 & Cantaloupes \\
\hline 36 & Alfalfa & 210 & Prunes \\
\hline 37 & Other Hay/Non Alfalfa & 211 & Olives \\
\hline 38 & Camelina & 212 & Oranges \\
\hline 39 & Buckwheat & 213 & Honeydew Melons \\
\hline 41 & Sugarbeets & 214 & Broccoli \\
\hline 42 & Dry Beans & 216 & Peppers \\
\hline 43 & Potatoes & 217 & Pomegranates \\
\hline 44 & Other Crops & 218 & Nectarines \\
\hline 45 & Sugarcane & 219 & Greens \\
\hline 46 & Sweet Potatoes & 220 & Plums \\
\hline 47 & Misc Vegs \& Fruits & 221 & Strawberries \\
\hline 48 & Watermelons & 222 & Squash \\
\hline 49 & Onions & 223 & Apricots \\
\hline 50 & Cucumbers & 224 & Vetch \\
\hline 51 & Chick Peas & 225 & Dbl Crop WinWht/Corn \\
\hline 52 & Lentils & 226 & Dbl Crop Oats/Corn \\
\hline 53 & Peas & 227 & Lettuce \\
\hline 54 & Tomatoes & 229 & Pumpkins \\
\hline
\end{tabular}




\begin{tabular}{|l|l|l|l|}
\hline $\begin{array}{l}\text { NASS ID } \\
\text { Value }\end{array}$ & Class Name & $\begin{array}{l}\text { NASS ID } \\
\text { Value }\end{array}$ & Class Name \\
\hline 55 & Cranberries & 230 & Dbl Crop Lettuce/Durum Wht \\
\hline 56 & Hops & 231 & Dbl Crop Lettuce/Cantaloupe \\
\hline 57 & Herbs & 232 & Dbl Crop Lettuce/Cotton \\
\hline 58 & Clover/Wildflowers & 233 & Dbl Crop Lettuce/Barley \\
\hline 59 & Sod/Grass Seed & 234 & $\begin{array}{l}\text { Dbl Crop Durum } \\
\text { Wht/Sorghum }\end{array}$ \\
\hline 60 & Switchgrass & 235 & Dbl Crop Barley/Sorghum \\
\hline 61 & Fallow/ldle Cropland & 236 & Dbl Crop WinWht/Sorghum \\
\hline 62 & Pasture/Grass & 237 & Dbl Crop Barley/Corn \\
\hline 63 & Forest & 238 & Dbl Crop Win Wht/Cotton \\
\hline 64 & Shrubland & 239 & Dbl Crop Soybeans/Cotton \\
\hline 65 & Barren & 240 & Dbl Crop Soybeans/Oats \\
\hline 66 & Cherries & 241 & Dbl Crop Corn/Soybeans \\
\hline 67 & Peaches & 242 & Blueberries \\
\hline 68 & Apples & 243 & Cabbage \\
\hline 69 & Grapes & 244 & Cauliflower \\
\hline 70 & Christmas Trees & 245 & Celery \\
\hline 71 & Other Tree Crops & 246 & Radishes \\
\hline 72 & Citrus & 247 & Turnips \\
\hline 74 & Pecans & 248 & Eggplants \\
\hline 75 & Almonds & 249 & Gourds \\
\hline 76 & Walnuts & 250 & Cranberries \\
\hline 77 & Pears & 254 & Dbl Crop Barley/Soybeans \\
\hline & & & \\
\hline
\end{tabular}




\section{Appendix D. Individual Field Crop Accuracy Results from eCognition Analyses}

\section{(based on field counts)}

\section{(Scenarios 1 through 4)}

Scenario 1a - overall class accuracies on a per field basis for 2001 Madera, 2002 Merced, 2011 Madera Data sets using 5\% training from the respective DWR ground survey for each data set.

\begin{tabular}{|l|c|c|c|}
\hline Crop Type & 2001 Madera & 2002 Merced & 2011 Madera \\
\hline Alfalfa & $73.2 \%$ & $79.5 \%$ & $74.3 \%$ \\
\hline Almond & $77.3 \%$ & $83.2 \%$ & $85.5 \%$ \\
\hline Apples & $26.2 \%$ & $0.0 \%$ & $6.6 \%$ \\
\hline Christmas Trees & $0.0 \%$ & $16.9 \%$ & $30.6 \%$ \\
\hline Corn & $77.0 \%$ & $48.3 \%$ & $53.0 \%$ \\
\hline Cotton & $96.2 \%$ & $74.9 \%$ & $66.6 \%$ \\
\hline Dry Beans & $71.9 \%$ & $49.3 \%$ & $48.7 \%$ \\
\hline Fallow/Idle cropland & $22.1 \%$ & $0.6 \%$ & $14.9 \%$ \\
\hline Grapes & $90.7 \%$ & $44.5 \%$ & $82.4 \%$ \\
\hline Olives & $36.5 \%$ & $11.2 \%$ & $28.4 \%$ \\
\hline Onions & $0.0 \%$ & $0.0 \%$ & $15.8 \%$ \\
\hline Oranges & $29.3 \%$ & $0.0 \%$ & $55.0 \%$ \\
\hline Other Hay/ Non Alfalfa & $79.4 \%$ & $\mathrm{n} / \mathrm{a}$ & $0.0 \%$ \\
\hline Pasture/Grass & $64.8 \%$ & $62.0 \%$ & $55.6 \%$ \\
\hline Peaches & $23.2 \%$ & $62.2 \%$ & $0.0 \%$ \\
\hline Pistachios & $65.0 \%$ & $0.0 \%$ & $56.2 \%$ \\
\hline Plums & $28.4 \%$ & $42.5 \%$ & $0.0 \%$ \\
\hline Prunes & $0.0 \%$ & $49.9 \%$ & $8.3 \%$ \\
\hline Sod/Grass Seed & $13.3 \%$ & $0.0 \%$ & $\mathrm{n} / \mathrm{a}$ \\
\hline Sudan & $63.0 \%$ & $\mathrm{n} / \mathrm{a}$ & $\mathrm{n} / \mathrm{a}$ \\
\hline Sugarbeets & $7.8 \%$ & $34.1 \%$ & $\mathrm{n} / \mathrm{a}$ \\
\hline Tomatoes & $33.8 \%$ & $54.7 \%$ & $0.0 \%$ \\
\hline Walnuts & $9.4 \%$ & $20.5 \%$ & $11.8 \%$ \\
\hline Watermelons & $0.0 \%$ & $20.0 \%$ & $0.0 \%$ \\
\hline
\end{tabular}


Scenario $1 b$ - overall class accuracies on a per field basis for 2001 Madera, 2002 Merced, 2011 Madera Data sets using 10\% training from the respective DWR ground survey for each data set.

\begin{tabular}{|l|c|c|c|}
\hline Crop Type & 2001 Madera & 2002 Merced & 2011 Madera \\
\hline Alfalfa & $84.5 \%$ & $78.6 \%$ & $80.8 \%$ \\
\hline Almond & $84.1 \%$ & $83.6 \%$ & $85.0 \%$ \\
\hline Apples & $28.4 \%$ & $29.1 \%$ & $8.1 \%$ \\
\hline Christmas Trees & $11.0 \%$ & $15.3 \%$ & $7.5 \%$ \\
\hline Corn & $77.3 \%$ & $56.3 \%$ & $77.0 \%$ \\
\hline Cotton & $97.4 \%$ & $85.6 \%$ & $74.0 \%$ \\
\hline Dry Beans & $60.4 \%$ & $49.2 \%$ & $52.6 \%$ \\
\hline Fallow/Idle cropland & $63.7 \%$ & $16.3 \%$ & $34.1 \%$ \\
\hline Grapes & $89.3 \%$ & $65.0 \%$ & $81.6 \%$ \\
\hline Olives & $46.5 \%$ & $29.9 \%$ & $1.4 \%$ \\
\hline Onions & $95.2 \%$ & $0.0 \%$ & $15.0 \%$ \\
\hline Oranges & $59.9 \%$ & $0.0 \%$ & $57.8 \%$ \\
\hline Other Hay/ Non Alfalfa & $62.7 \%$ & $\mathrm{n} / \mathrm{a}$ & $0.0 \%$ \\
\hline Pasture/Grass & $58.8 \%$ & $62.4 \%$ & $57.5 \%$ \\
\hline Peaches & $24.5 \%$ & $53.1 \%$ & $0.0 \%$ \\
\hline Pistachios & $68.5 \%$ & $0.0 \%$ & $66.9 \%$ \\
\hline Plums & $30.8 \%$ & $33.9 \%$ & $29.0 \%$ \\
\hline Prunes & $4.6 \%$ & $23.2 \%$ & $24.1 \%$ \\
\hline Sod/Grass Seed & $40.9 \%$ & $0.0 \%$ & $\mathrm{n} / \mathrm{a}$ \\
\hline Sudan & $45.7 \%$ & $\mathrm{n} / \mathrm{a}$ & $\mathrm{n} / \mathrm{a}$ \\
\hline Sugarbeets & $53.0 \%$ & $69.1 \%$ & $\mathrm{n} / \mathrm{a}$ \\
\hline Tomatoes & $41.5 \%$ & $61.5 \%$ & $89.6 \%$ \\
\hline Walnuts & $17.3 \%$ & $29.8 \%$ & $16.9 \%$ \\
\hline Watermelons & $0.0 \%$ & $51.3 \%$ & $0.0 \%$ \\
\hline
\end{tabular}


Scenario 1c - overall class accuracies on a per field basis for 2001 Madera, 2002 Merced, 2011 Madera Data sets using 20\% training from the respective DWR ground survey for each data set.

\begin{tabular}{|l|c|c|c|}
\hline Crop Type & 2001 Madera & 2002 Merced & 2011 Madera \\
\hline Alfalfa & $88.6 \%$ & $85.6 \%$ & $87.3 \%$ \\
\hline Almond & $86.5 \%$ & $89.2 \%$ & $89.3 \%$ \\
\hline Apples & $53.9 \%$ & $3.0 \%$ & $33.4 \%$ \\
\hline Christmas Trees & $45.0 \%$ & $26.8 \%$ & $21.1 \%$ \\
\hline Corn & $87.5 \%$ & $72.4 \%$ & $72.6 \%$ \\
\hline Cotton & $94.0 \%$ & $88.3 \%$ & $74.0 \%$ \\
\hline Dry Beans & $69.8 \%$ & $62.2 \%$ & $89.5 \%$ \\
\hline Fallow/Idle cropland & $36.9 \%$ & $11.7 \%$ & $45.6 \%$ \\
\hline Grapes & $91.8 \%$ & $66.0 \%$ & $87.8 \%$ \\
\hline Olives & $71.8 \%$ & $11.2 \%$ & $33.7 \%$ \\
\hline Onions & $72.2 \%$ & $0.0 \%$ & $69.2 \%$ \\
\hline Oranges & $60.5 \%$ & $10.7 \%$ & $62.9 \%$ \\
\hline Other Hay/ Non Alfalfa & $80.8 \%$ & $\mathrm{n} / \mathrm{a}$ & $0.0 \%$ \\
\hline Pasture/Grass & $60.1 \%$ & $71.0 \%$ & $77.7 \%$ \\
\hline Peaches & $37.1 \%$ & $73.1 \%$ & $0.0 \%$ \\
\hline Pistachios & $82.5 \%$ & $0.0 \%$ & $75.6 \%$ \\
\hline Plums & $52.4 \%$ & $20.6 \%$ & $43.4 \%$ \\
\hline Prunes & $21.0 \%$ & $68.8 \%$ & $41.7 \%$ \\
\hline Sod/Grass Seed & $52.3 \%$ & $0.0 \%$ & $\mathrm{n} / \mathrm{a}$ \\
\hline Sudan & $66.7 \%$ & $\mathrm{n} / \mathrm{a}$ & $\mathrm{n} / \mathrm{a}$ \\
\hline Sugarbeets & $20.1 \%$ & $80.2 \%$ & $\mathrm{n} / \mathrm{a}$ \\
\hline Tomatoes & $30.7 \%$ & $67.4 \%$ & $78.8 \%$ \\
\hline Walnuts & $12.3 \%$ & $35.6 \%$ & $49.9 \%$ \\
\hline Watermelons & $42.1 \%$ & $72.8 \%$ & $67.4 \%$ \\
\hline
\end{tabular}


Scenario 2 - Overall Class Accuracies for 2002 Merced and 2011 Madera Data sets using 90\% training date from 2001 DWR ground survey

\begin{tabular}{|l|c|c|}
\hline Crop Type & 2002 Merced & 2011 Madera \\
\hline Alfalfa & $80 \%$ & $84 \%$ \\
\hline Almond & $83 \%$ & $78 \%$ \\
\hline Apples & $0 \%$ & $0 \%$ \\
\hline Christmas Trees & $29 \%$ & $0 \%$ \\
\hline Corn & $58 \%$ & $89 \%$ \\
\hline Cotton & $67 \%$ & $49 \%$ \\
\hline Dry Beans & $1 \%$ & $4 \%$ \\
\hline Fallow/Idle cropland & $5 \%$ & $12 \%$ \\
\hline Grapes & $75 \%$ & $83 \%$ \\
\hline Olives & $30 \%$ & $2 \%$ \\
\hline Onions & $0 \%$ & $0 \%$ \\
\hline Oranges & $0 \%$ & $35 \%$ \\
\hline Other Hay/ Non Alfalfa & $\mathrm{n} / \mathrm{a}$ & $0 \%$ \\
\hline Pasture/Grass & $33 \%$ & $43 \%$ \\
\hline Peaches & $25 \%$ & $0 \%$ \\
\hline Pistachios & $0 \%$ & $39 \%$ \\
\hline Plums & $3 \%$ & $1 \%$ \\
\hline Prunes & $0 \%$ & $0 \%$ \\
\hline Sod/Grass Seed & $0 \%$ & $\mathrm{n} / \mathrm{a}$ \\
\hline Sudan & $\mathrm{n} / \mathrm{a}$ & $\mathrm{n} / \mathrm{a}$ \\
\hline Sugarbeets & $16 \%$ & $\mathrm{n} / \mathrm{a}$ \\
\hline Tomatoes & $4 \%$ & $62 \%$ \\
\hline Walnuts & $1 \%$ & $13 \%$ \\
\hline Watermelons & $2 \%$ & $12 \%$ \\
\hline
\end{tabular}


Scenario 3 - Overall Class Accuracies for 2002 Merced and 2011 Madera Data sets using $90 \%$ training date from 2001 DWR ground survey and $10 \%$ from the respective DWR Ground Survey for each data set

\begin{tabular}{|l|c|c|}
\hline Crop Type & 2002 Merced & 2011 Madera \\
\hline Alfalfa & $80.9 \%$ & $86.5 \%$ \\
\hline Almond & $85.3 \%$ & $85.5 \%$ \\
\hline Apples & $29.1 \%$ & $7.7 \%$ \\
\hline Christmas Trees & $10.5 \%$ & $7.5 \%$ \\
\hline Corn & $63.3 \%$ & $89.4 \%$ \\
\hline Cotton & $86.0 \%$ & $69.9 \%$ \\
\hline Dry Beans & $56.3 \%$ & $4.2 \%$ \\
\hline Fallow/Idle cropland & $12.5 \%$ & $31.7 \%$ \\
\hline Grapes & $66.4 \%$ & $84.1 \%$ \\
\hline Olives & $29.9 \%$ & $3.5 \%$ \\
\hline Onions & $0.0 \%$ & $15.0 \%$ \\
\hline Oranges & $73.5 \%$ & $56.6 \%$ \\
\hline Other Hay/ Non Alfalfa & $\mathrm{n} / \mathrm{a}$ & $0.0 \%$ \\
\hline Pasture/Grass & $68.2 \%$ & $59.1 \%$ \\
\hline Peaches & $59.5 \%$ & $0.0 \%$ \\
\hline Pistachios & $57.7 \%$ & $63.2 \%$ \\
\hline Plums & $30.7 \%$ & $29.6 \%$ \\
\hline Prunes & $45.2 \%$ & $24.1 \%$ \\
\hline Sod/Grass Seed & $0.0 \%$ & $\mathrm{n} / \mathrm{a}$ \\
\hline Sudan & $\mathrm{n} / \mathrm{a}$ & $\mathrm{n} / \mathrm{a}$ \\
\hline Sugarbeets & $60.2 \%$ & $\mathrm{n} / \mathrm{a}$ \\
\hline Tomatoes & $61.3 \%$ & $69.4 \%$ \\
\hline Walnuts & $31.3 \%$ & $27.9 \%$ \\
\hline Watermelons & $43.8 \%$ & $12.5 \%$ \\
\hline
\end{tabular}


Scenario 4 - Overall Classification Results for 2011 Madera data analysis using $90 \%$ of 2001 DWR ground survey and 10\% 2011 DWR ground survey as training data. Comparison of results with and without the feature space of Actual Crop Coefficient (EToF)

\begin{tabular}{|l|c|c|}
\hline \multicolumn{1}{|c|}{ Crop Type } & \multicolumn{2}{c|}{2011 Madera } \\
\hline Alfalfa & EtoF & No EtoF \\
\hline Almond & $86.5 \%$ & $76.3 \%$ \\
\hline Apples & $85.5 \%$ & $83.7 \%$ \\
\hline Christmas Trees & $7.7 \%$ & $4.5 \%$ \\
\hline Corn & $7.5 \%$ & $7.7 \%$ \\
\hline Cotton & $89.4 \%$ & $69.7 \%$ \\
\hline Dry Beans & $69.9 \%$ & $72.5 \%$ \\
\hline Fallow/Idle cropland & $4.2 \%$ & $0.0 \%$ \\
\hline Grapes & $31.7 \%$ & $32.6 \%$ \\
\hline Olives & $84.1 \%$ & $77.3 \%$ \\
\hline Onions & $3.5 \%$ & $5.1 \%$ \\
\hline Oranges & $15.0 \%$ & $15.0 \%$ \\
\hline Other Hay/ Non Alfalfa & $56.6 \%$ & $66.0 \%$ \\
\hline Pasture/Grass & $0.0 \%$ & $0.0 \%$ \\
\hline Peaches & $59.1 \%$ & $40.6 \%$ \\
\hline Pistachios & $0.0 \%$ & $0.0 \%$ \\
\hline Plums & $63.2 \%$ & $63.7 \%$ \\
\hline Prunes & $29.6 \%$ & $25.7 \%$ \\
\hline Sod/Grass Seed & $24.1 \%$ & $19.9 \%$ \\
\hline Sudan & n/a & n/a \\
\hline Sugarbeets & n/a & n/a \\
\hline Tomatoes & n/a & n/a \\
\hline Walnuts & $69.4 \%$ & $92.8 \%$ \\
\hline Watermelons & $27.9 \%$ & $18.4 \%$ \\
\hline & $12.5 \%$ & $0.0 \%$ \\
\hline
\end{tabular}




\title{
Appendix E. Crop Confusion Matrices Resulting from eCognition Analyses
}

\author{
(based of field count)
}

(Scenarios 1 through 4)

2001 Confusion Matrix - Utilizing 5\% of DWR ground survey data from 2001.

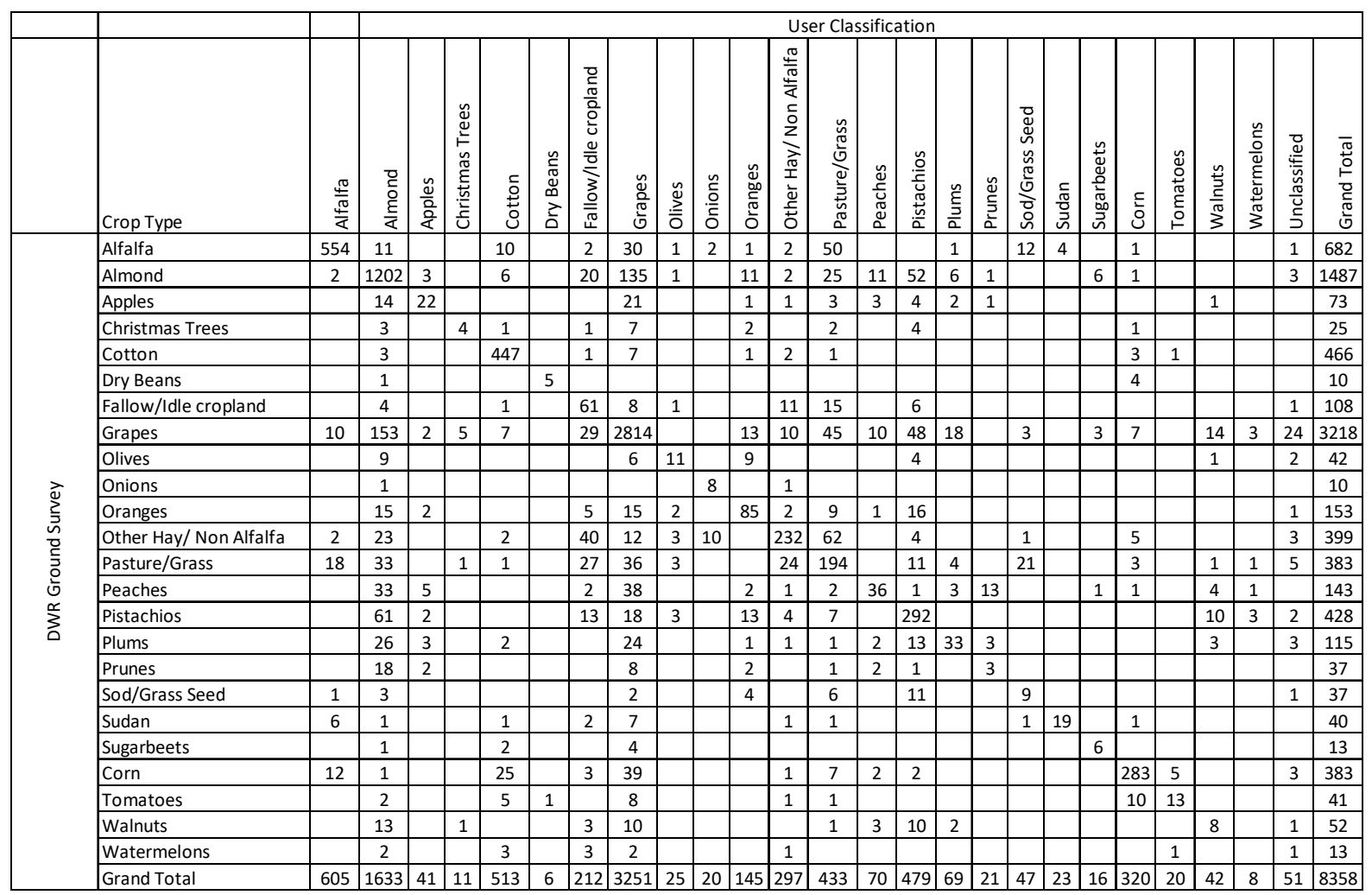


2002 Merced Confusion Matrix - Utilizing 5\% of DWR ground survey data from 2002 Merced.

\begin{tabular}{|c|c|c|c|c|c|c|c|c|c|c|c|c|c|c|c|c|c|c|c|c|c|c|c|c|c|c|c|}
\hline & & & \multicolumn{25}{|c|}{ User Classification } \\
\hline & Crop Type & $\begin{array}{l}\frac{\pi}{\frac{\pi}{5}} \\
\frac{\sqrt{5}}{4}\end{array}$ & 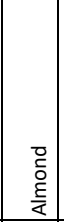 & $\frac{\tilde{\omega}}{\frac{0}{2}}$ & 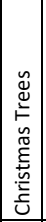 & 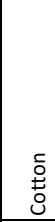 & $\begin{array}{l}0 \\
\check{c} \\
\mathbb{2} \\
\infty \\
\geq \\
\vdots \\
0\end{array}$ & 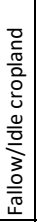 & $\begin{array}{l}\tilde{0} \\
\frac{0}{0} \\
\frac{\pi}{0}\end{array}$ & $\stackrel{\check{\beth}}{\stackrel{\check{O}}{0}}$ & $\begin{array}{l}\text { ֻ } \\
.0 \\
\text { ¿ }\end{array}$ & $\begin{array}{l}\tilde{0} \\
\text { do } \\
\tilde{\pi} \\
\tilde{0}\end{array}$ & 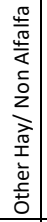 & 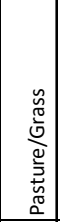 & 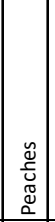 & 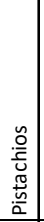 & $\frac{\tilde{\xi}}{a}$ & $\begin{array}{l}\tilde{y} \\
\stackrel{5}{2} \\
\underline{2} \\
0\end{array}$ & 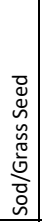 & $\begin{array}{l}c \\
\frac{1}{0} \\
0 \\
5 \\
\end{array}$ & 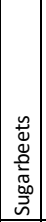 & క & $\begin{array}{l}\tilde{J} \\
0 \\
0 \\
\tilde{0} \\
\tilde{E} \\
0\end{array}$ & $\begin{array}{l}\frac{n}{3} \\
\frac{5}{n} \\
\frac{n}{3}\end{array}$ & 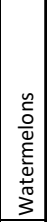 & 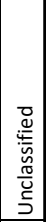 & 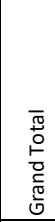 \\
\hline \multirow{25}{*}{ 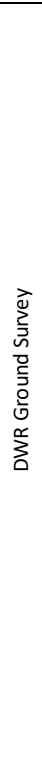 } & Alfalfa & 1374 & 99 & 1 & & 58 & 4 & 5 & 6 & 5 & & & & 165 & 13 & & 9 & 1 & & & & 20 & 27 & 7 & 1 & 15 & 1810 \\
\hline & Almond & 22 & 2224 & 1 & 3 & 52 & 1 & 2 & 46 & 1 & & 6 & & 148 & 68 & 23 & 25 & & & & & 24 & 7 & 94 & & 27 & 2774 \\
\hline & Apples & 1 & 4 & 2 & & 2 & & & 1 & & & & & 3 & 4 & & & & & & & 1 & & & & & 18 \\
\hline & Christmas Trees & & 7 & & 7 & 3 & & & 1 & 6 & & & & 7 & 1 & 2 & 2 & & & & & & 1 & 7 & & 3 & 47 \\
\hline & Cotton & 48 & 37 & & 6 & 1042 & 15 & 7 & 17 & 19 & & & & 54 & 13 & 1 & 6 & & & & & 67 & 111 & 29 & 10 & 21 & 1503 \\
\hline & Dry Beans & 1 & 4 & & & & 8 & 1 & & & & & & 5 & 1 & & & & & & & & & & & 1 & 21 \\
\hline & Fallow/Idle cropland & 7 & 3 & & & 13 & 66 & 1 & 1 & & & & & 6 & 1 & & 3 & & & & & 3 & 17 & 2 & 1 & 1 & 125 \\
\hline & Grapes & 1 & 3 & & & 5 & & 1 & 66 & 1 & & & & 3 & 3 & & & & & & & 10 & 3 & 7 & 2 & 3 & 108 \\
\hline & Olives & 10 & 56 & & & 6 & & 2 & 103 & 33 & & & & 43 & 38 & 1 & 3 & & & & & 4 & & 17 & & 3 & 319 \\
\hline & Onions & & & & & & & & & 1 & & & & & & & & & & & & & & 2 & & & 3 \\
\hline & Oranges & & & & & 1 & & & & & & & & & & & & & & & & & & & & 3 & 4 \\
\hline & Other Hay/ Non Alfalfa & 1 & 1 & & & & & & & & & & & 1 & & & & & & & & & & & & & 3 \\
\hline & Pasture/Grass & 97 & 218 & 1 & 1 & 37 & & 1 & 22 & 1 & & & & 751 & 30 & 6 & 23 & & & & 1 & 9 & 9 & 45 & 2 & 15 & 1269 \\
\hline & Peaches & 4 & 78 & & & 3 & & 1 & 12 & & & 1 & & 19 & 196 & & 7 & & & & & 2 & & 24 & & 4 & 351 \\
\hline & \begin{tabular}{|l|} 
Pistachios \\
\end{tabular} & & & & & & & & & & & & & & 1 & & & & & & & & & & & & 1 \\
\hline & Plums & & & & & & & & & & & & & & & & 3 & 1 & & & & & & & & 0 & 4 \\
\hline & Prunes & & 16 & & & 2 & & & 1 & 4 & & 4 & & 4 & & 1 & 1 & 41 & & & & & & 3 & & 0 & 77 \\
\hline & Sod/Grass Seed & 1 & 6 & & & 1 & & & & & & & & 4 & 5 & 1 & 15 & & & & & 2 & & 1 & & 0 & 36 \\
\hline & Sudan & & 13 & & 1 & & & & 1 & & & & & 1 & & & 2 & 14 & & & & & & 2 & & 0 & 34 \\
\hline & Sugarbeets & 26 & 3 & & & 20 & & 1 & & & & & & 3 & 1 & & 1 & & & & 30 & 1 & & 1 & & 0 & 87 \\
\hline & Corn & 28 & 31 & & 1 & 44 & 13 & & 9 & 2 & & & & 18 & 2 & 3 & 2 & & & & & 160 & 78 & 3 & 5 & 9 & 408 \\
\hline & Tomatoes & 12 & 24 & & 2 & 85 & 21 & 2 & 9 & 1 & & & & 10 & & 1 & 7 & & & & 2 & 48 & 281 & 9 & 8 & 15 & 537 \\
\hline & Walnuts & 4 & 130 & & & 4 & 1 & & 9 & & & 1 & & 34 & 44 & 4 & 8 & & & & & 4 & 1 & 63 & & 3 & 310 \\
\hline & Watermelons & 2 & 13 & & 2 & 15 & 14 & 1 & 2 & 1 & & & & 11 & 3 & & 2 & & & & & 3 & 15 & 5 & 21 & & 110 \\
\hline & Grand Total & 1639 & 2970 & 5 & 23 & 1393 & 143 & 25 & 306 & 75 & 0 & 12 & 0 & 1290 & 424 & 43 & 119 & 57 & 0 & 0 & 33 & 358 & 550 & 321 & 50 & 144 & 9959 \\
\hline
\end{tabular}


2011 Confusion Matrix - Utilizing 5\% of DWR ground survey data from 2011.

\begin{tabular}{|c|c|c|c|c|c|c|c|c|c|c|c|c|c|c|c|c|c|c|c|c|c|c|c|c|c|c|c|}
\hline & & & \multicolumn{25}{|c|}{ User Classification } \\
\hline & Crop Type & $\begin{array}{l}\frac{\pi}{\pi} \\
\frac{\pi}{2} \\
\end{array}$ & 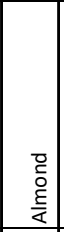 & $\frac{\tilde{c}}{\frac{0}{2}}$ & 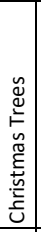 & $\begin{array}{l}5 \\
0 \\
0 \\
0\end{array}$ & 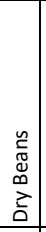 & 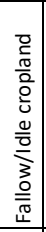 & $\begin{array}{l}\breve{\Xi} \\
\stackrel{0}{0} \\
\mathbb{0}\end{array}$ & $\stackrel{\tilde{\Xi}}{\stackrel{\Xi}{0}}$ & $\begin{array}{l}\tilde{\swarrow} \\
.0 \\
\check{c} \\
\end{array}$ & $\begin{array}{l}\tilde{d} \\
0 \\
0 \\
\tilde{0} \\
\tilde{0} \\
\end{array}$ & 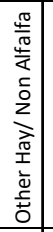 & 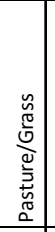 & 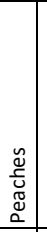 & 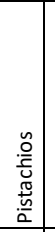 & $\frac{\underline{\xi}}{3}$ & 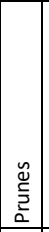 & 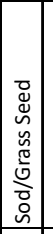 & $\begin{array}{l}\frac{c}{\pi} \\
\frac{\pi}{0} \\
n \\
n\end{array}$ & 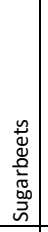 & $\begin{array}{l}5 \\
0 \\
\end{array}$ & 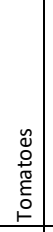 & $\begin{array}{c}\frac{n}{3} \\
\frac{5}{n} \\
3\end{array}$ & 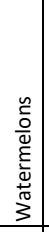 & 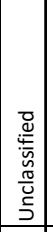 & $\begin{array}{l}\bar{\pi} \\
0 \\
0 \\
0 \\
0 \\
\frac{0}{0} \\
0 \\
\end{array}$ \\
\hline \multirow{25}{*}{ 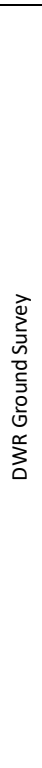 } & Alfalfa & 355 & 33 & & & 5 & & 5 & 31 & & 4 & & & 50 & & 1 & & & & & & 12 & & 1 & & & 497 \\
\hline & Almond & 15 & 1719 & 6 & 6 & 35 & & 57 & 127 & 5 & 7 & 28 & & 9 & & 51 & & & & & & & & 1 & & 13 & 2079 \\
\hline & Apples & 2 & 26 & 3 & 1 & 4 & & 7 & 8 & & & 3 & & 4 & & 3 & & & & & & 1 & & 1 & & 3 & 66 \\
\hline & Christmas Trees & & 4 & & 6 & 2 & & & 6 & & & 1 & & & & & & & & & & & & & & 5 & 24 \\
\hline & Cotton & 10 & 32 & & 6 & 128 & & 11 & 30 & 1 & 4 & 4 & & 4 & & & & & & & & 2 & & & & 3 & 235 \\
\hline & Dry Beans & & 1 & & & & 11 & & 3 & & & & & & & 1 & & & & & & 8 & & & & & 24 \\
\hline & Fallow/Idle cropland & 8 & 33 & & 1 & 43 & & 33 & 22 & & 2 & 2 & & 2 & & 6 & & & & & & & & 2 & & & 154 \\
\hline & Grapes & 12 & 182 & 12 & 24 & 25 & & 20 & 1305 & 2 & & 29 & & 7 & & 32 & & & & & & & & & & 33 & 1683 \\
\hline & \begin{tabular}{|l|} 
Olives \\
\end{tabular} & & 6 & & 3 & 2 & & 15 & 8 & 6 & & 4 & & & & 3 & & & & & & & & & & 2 & 49 \\
\hline & Onions & & 1 & & & 1 & & & 1 & & 1 & & & & & & & & & & & & & & & & 4 \\
\hline & Oranges & 2 & 31 & 1 & 2 & & & & 10 & 1 & & 74 & & & & 26 & & & & & & 1 & & & & 4 & 152 \\
\hline & Other Hay/ Non Alfalfa & 15 & 47 & & & 11 & & 4 & 46 & 4 & & 4 & & 69 & & 4 & & & & & & & & 1 & & 14 & 219 \\
\hline & Pasture/Grass & & 27 & 1 & & 1 & & & & & & 2 & & 14 & & 2 & & & & & & & & & & 2 & 49 \\
\hline & \begin{tabular}{|l|} 
Peaches \\
\end{tabular} & & 1 & & & & & & & & & & & & & & & & & & & & & & & & 1 \\
\hline & Pistachios & 16 & 84 & 2 & 3 & 10 & & 26 & 37 & 6 & & 25 & & 4 & & 194 & & & & & & & & 1 & & 12 & 420 \\
\hline & \begin{tabular}{|l|} 
Plums \\
\end{tabular} & & 14 & & & 1 & & & 2 & & & & & 1 & & 2 & & & & & & & & & & & 20 \\
\hline & Prunes & & 14 & & & 1 & & & 1 & & & & & & & 1 & & 2 & & & & & & & & 1 & 20 \\
\hline & Sod/Grass Seed & & & & & & & & & & & & & & & & & & & & & & & & & & 0 \\
\hline & Sudan & & & & & & & & & & & & & & & & & & & & & & & & & & 0 \\
\hline & Sugarbeets & & & & & & & & & & & & & & & & & & & & & & & & & & 0 \\
\hline & Corn & 4 & 7 & & 1 & 9 & & & 34 & & & 1 & & 2 & & & & & & & & 66 & & & & 5 & 129 \\
\hline & \begin{tabular}{|l} 
Tomatoes \\
\end{tabular} & 1 & 1 & & & 5 & 3 & 2 & 5 & & & & & & & & & & & & & 24 & & & & 11 & 52 \\
\hline & \begin{tabular}{|l} 
Walnuts \\
\end{tabular} & & 30 & & & 5 & & & 3 & & & & & 3 & & 1 & & & & & & & & 5 & & 1 & 48 \\
\hline & \begin{tabular}{|l|} 
Watermelons \\
\end{tabular} & & 3 & 1 & 1 & 1 & & & 3 & & & & & & & & & & & & & & & & & 1 & 10 \\
\hline & Grand Total & 440 & 2296 & 26 & 54 & 289 & 14 & 180 & 1682 & 25 & \begin{tabular}{l|l}
18 & 1 \\
\end{tabular} & 177 & 0 & 169 & 0 & \begin{tabular}{|l|l|}
327 \\
\end{tabular} & 0 & 2 & 0 & 0 & 0 & 114 & 0 & 12 & 이 & 110 & 5935 \\
\hline
\end{tabular}


2001 Confusion Matrix - Utilizing 10\% of DWR ground survey data from 2001.

\begin{tabular}{|c|c|c|c|c|c|c|c|c|c|c|c|c|c|c|c|c|c|c|c|c|c|c|c|c|c|c|c|}
\hline & & & \multicolumn{25}{|c|}{ User Classification } \\
\hline & Crop Type & $\frac{\frac{\pi}{4}}{\frac{\pi}{\pi}}$ & 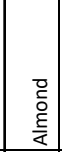 & $\frac{\tilde{c}}{\frac{0}{2}}$ & 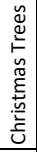 & $\begin{array}{l}5 \\
0 \\
0 \\
0 \\
0\end{array}$ & $\begin{array}{l}n \\
\check{c} \\
\mathbb{D} \\
\infty \\
\geq \\
0\end{array}$ & 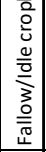 & $\begin{array}{l}\breve{d} \\
\frac{0}{0} \\
\frac{0}{0}\end{array}$ & $\stackrel{n}{\stackrel{\Xi}{0}}$ & 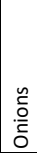 & 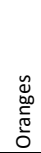 & 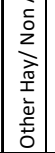 & 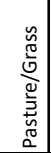 & 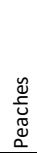 & 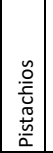 & $\frac{\tilde{\xi}}{a}$ & 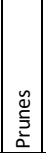 & 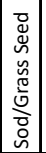 & $\begin{array}{c}c \\
\frac{1}{0} \\
\frac{5}{5} \\
\end{array}$ & 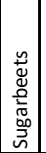 & ¿ & 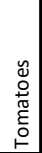 & $\begin{array}{l}\frac{n}{5} \\
\frac{5}{\pi} \\
\frac{\pi}{3}\end{array}$ & 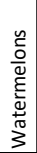 & 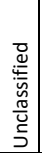 & 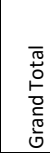 \\
\hline \multirow{25}{*}{ 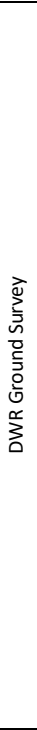 } & Alfalfa & 554 & 11 & & & 10 & & 2 & 30 & 1 & 2 & 1 & 2 & 50 & & & 1 & & 12 & 4 & & 1 & & & & 1 & 682 \\
\hline & Almond & 2 & 1202 & 3 & & 6 & & 20 & 135 & 1 & & 11 & 2 & 25 & 11 & 52 & 6 & 1 & & & 6 & 1 & & & & 3 & 1487 \\
\hline & Apples & & 14 & 22 & & & & & 21 & & & 1 & 1 & 3 & 3 & 4 & 2 & 1 & & & & & & 1 & & & 73 \\
\hline & Christmas Trees & & 3 & & 4 & 1 & & 1 & 7 & & & 2 & & 2 & & 4 & & & & & & 1 & & & & & 25 \\
\hline & Cotton & & 3 & & & 447 & & 1 & 7 & & & 1 & 2 & 1 & & & & & & & & 3 & 1 & & & & 466 \\
\hline & \begin{tabular}{|l|} 
Dry Beans \\
\end{tabular} & & 1 & & & & 5 & & & & & & & & & & & & & & & 4 & & & & & 10 \\
\hline & Fallow/Idle cropland & & 4 & & & 1 & & 61 & 8 & 1 & & & 11 & 15 & & 6 & & & & & & & & & & 1 & 108 \\
\hline & Grapes & 10 & 153 & 2 & 5 & 7 & & 29 & 2814 & & & 13 & 10 & 45 & 10 & 48 & 18 & & 3 & & 3 & 7 & & 14 & 3 & 24 & 3218 \\
\hline & Olives & & 9 & & & & & & 6 & 11 & & 9 & & & & 4 & & & & & & & & 1 & & 2 & 42 \\
\hline & Onions & & 1 & & & & & & & & 8 & & 1 & & & & & & & & & & & & & & 10 \\
\hline & Oranges & & 15 & 2 & & & & 5 & 15 & 2 & & 85 & 2 & 9 & 1 & 16 & & & & & & & & & & 1 & 153 \\
\hline & Other Hay/ Non Alfalfa & 2 & 23 & & & 2 & & 40 & 12 & 3 & 10 & & 232 & 62 & & 4 & & & 1 & & & 5 & & & & 3 & 399 \\
\hline & Pasture/Grass & 18 & 33 & & 1 & 1 & & 27 & 36 & 3 & & & 24 & 194 & & 11 & 4 & & 21 & & & 3 & & 1 & 1 & 5 & 383 \\
\hline & Peaches & & 33 & 5 & & & & 2 & 38 & & & 2 & 1 & 2 & 36 & 1 & 3 & 13 & & & 1 & 1 & & 4 & 1 & & 143 \\
\hline & \begin{tabular}{|l|} 
Pistachios \\
\end{tabular} & & 61 & 2 & & & & 13 & 18 & 3 & & 13 & 4 & 7 & & 292 & & & & & & & & 10 & 3 & 2 & 428 \\
\hline & \begin{tabular}{|l|} 
Plums \\
\end{tabular} & & 26 & 3 & & 2 & & & 24 & & & 1 & 1 & 1 & 2 & 13 & 33 & 3 & & & & & & 3 & & 3 & 115 \\
\hline & Prunes & & 18 & 2 & & & & & 8 & & & 2 & & 1 & 2 & 1 & & 3 & & & & & & & & & 37 \\
\hline & Sod/Grass Seed & 1 & 3 & & & & & & 2 & & & 4 & & 6 & & 11 & & & 9 & & & & & & & 1 & 37 \\
\hline & Sudan & 6 & 1 & & & 1 & & 2 & 7 & & & & 1 & 1 & & & & & 1 & \begin{tabular}{|l|l}
19 \\
\end{tabular} & & 1 & & & & & 40 \\
\hline & \begin{tabular}{|l|} 
Sugarbeets \\
\end{tabular} & & 1 & & & 2 & & & 4 & & & & & & & & & & & & 6 & & & & & & 13 \\
\hline & Corn & 12 & 1 & & & 25 & & 3 & 39 & & & & 1 & 7 & 2 & 2 & & & & & & 283 & 5 & & & 3 & 383 \\
\hline & Tomatoes & & 2 & & & 5 & 1 & & 8 & & & & 1 & 1 & & & & & & & & 10 & 13 & & & & 41 \\
\hline & Walnuts & & 13 & & 1 & & & 3 & 10 & & & & & 1 & 3 & 10 & 2 & & & & & & & 8 & & 1 & 52 \\
\hline & Watermelons & & 2 & & & 3 & & 3 & 2 & & & & 1 & & & & & & & & & & 1 & & & 1 & 13 \\
\hline & Grand Total & 605 & 1633 & 41 & 11 & 513 & 6 & 212 & 3251 & 25 & 20 & 145 & 297 & 433 & 70 & 479 & 69 & 21 & 47 & 23 & 16 & 320 & 20 & 42 & 8 & 51 & 8358 \\
\hline
\end{tabular}


2002 Merced Confusion Matrix - Utilizing 10\% of DWR ground survey data from 2002 Merced.

\begin{tabular}{|c|c|c|c|c|c|c|c|c|c|c|c|c|c|c|c|c|c|c|c|c|c|c|c|c|c|c|c|}
\hline & & & \multicolumn{25}{|c|}{ User Classification } \\
\hline & Crop Type & $\begin{array}{l}\frac{\pi}{4} \\
\frac{\pi}{4} \\
\end{array}$ & 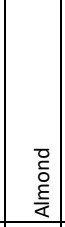 & $\frac{\tilde{u}}{\frac{0}{0}}$ & 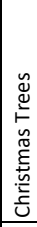 & \begin{tabular}{l}
0 \\
0 \\
\multirow{0}{0}{} \\
\end{tabular} & 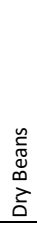 & 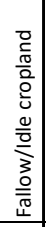 & $\begin{array}{l}\mathscr{0} \\
\frac{0}{0} \\
\frac{0}{0}\end{array}$ & $\stackrel{\check{\Perp}}{\grave{\Xi}}$ & $\begin{array}{l}气 \\
\stackrel{0}{\Xi} \\
\bar{\delta}\end{array}$ & $\begin{array}{l}\tilde{u} \\
\text { o. } \\
\overline{0} \\
\text { ప }\end{array}$ & 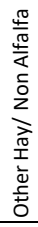 & 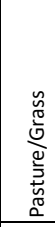 & $\begin{array}{l}\tilde{q} \\
\bar{c} \\
\tilde{\Xi} \\
\tilde{Q}\end{array}$ & $\begin{array}{l}\tilde{n} \\
\frac{0}{\delta} \\
\frac{0}{\pi} \\
. \frac{5}{2} \\
\end{array}$ & $\frac{\xi}{\frac{\xi}{a}}$ & \begin{tabular}{l} 
凹 \\
\multirow{2}{2}{} \\
$\frac{2}{2}$
\end{tabular} & 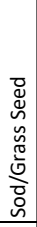 & $\begin{array}{l}\frac{c}{\sqrt{0}} \\
\frac{0}{5} \\
n \\
\end{array}$ & 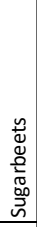 & 둔 & 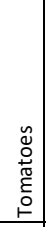 & $\begin{array}{l}\frac{n}{3} \\
\frac{\vec{c}}{\pi} \\
3 \\
3\end{array}$ & 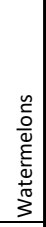 & 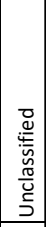 & 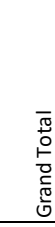 \\
\hline \multirow{25}{*}{ 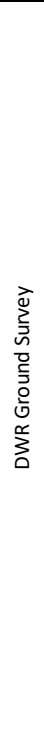 } & Alfalfa & 1352 & 78 & 1 & & 63 & 4 & 1 & 15 & 2 & & & & 194 & 14 & 4 & & 1 & & & 2 & 21 & 29 & 12 & 4 & 13 & 1810 \\
\hline & Almond & 15 & 2229 & 1 & 8 & 40 & & 45 & 52 & 6 & & 6 & & 130 & 53 & 40 & 1 & 3 & & & 2 & 9 & 5 & 88 & 8 & 33 & 2774 \\
\hline & Apples & & 6 & 2 & & 1 & & & 2 & & & & & 1 & 4 & & & & & & & 1 & & 1 & & & 18 \\
\hline & Christmas Trees & 2 & 11 & & 10 & 3 & & 1 & 3 & & & & & 6 & 2 & 1 & 1 & & & & & & 3 & 3 & & 1 & 47 \\
\hline & Cotton & 25 & 51 & & 2 & 1166 & 8 & 32 & 10 & 1 & & & & 47 & 6 & 8 & & 1 & & & 3 & 23 & 69 & 22 & 16 & 13 & 1503 \\
\hline & Dry Beans & & 2 & & 1 & & 12 & 1 & 2 & & & & & 2 & 1 & & & & & & & & & & & & 21 \\
\hline & Fallow/Idle cropland & 5 & 5 & & 2 & 23 & 31 & 31 & & & & & & 2 & & 1 & & & & & & 4 & 10 & 5 & 5 & 1 & 125 \\
\hline & Grapes & 2 & 6 & & & 18 & & 5 & 54 & & & & & 5 & 2 & 3 & & 1 & & & 2 & 2 & 4 & 1 & & 3 & 108 \\
\hline & Olives & 6 & 39 & & & 4 & & 3 & 112 & 62 & & & & 33 & 31 & 9 & & & & & & 1 & 2 & 9 & 2 & 6 & 319 \\
\hline & Onions & & & & 1 & & & & & 1 & & & & & & 1 & & & & & & & & & & & 3 \\
\hline & Oranges & & & & & & & & & & & & & & & & & & & & & 1 & 1 & & & 2 & 4 \\
\hline & Other Hay/ Non Alfalfa & & 1 & & & & & & & & & 1 & & 1 & & & & & & & & & & & & & 3 \\
\hline & Pasture/Grass & 85 & 179 & 1 & 4 & 40 & 2 & 8 & 34 & 1 & & & & 776 & 29 & 12 & & 2 & & & 15 & 18 & 11 & 33 & 6 & 13 & 1269 \\
\hline & Peaches & 1 & 83 & & 2 & 2 & & 2 & 17 & 4 & & 1 & & 23 & 172 & 3 & & 1 & & & & & & 35 & & 5 & 351 \\
\hline & \begin{tabular}{|l|} 
Pistachios \\
\end{tabular} & & & & & & & & & & & & & & 1 & & & & & & & & & & & & 1 \\
\hline & Plums & & & & & & & & & & & & & & & & 1 & & & & & & 3 & & & & 4 \\
\hline & Prunes & & 20 & & & 4 & & & & 2 & & 2 & & & & 21 & & 24 & & & & & 1 & 2 & & 1 & 77 \\
\hline & Sod/Grass Seed & & 17 & & & 1 & & & & & & & & 1 & 3 & 2 & 9 & 2 & & & & & & 1 & & & 36 \\
\hline & Sudan & & 6 & & 3 & 1 & & & 1 & & & & & & & 5 & 8 & 10 & & & & & & & & & 34 \\
\hline & Sugarbeets & 1 & 1 & & & 18 & 1 & 1 & & & & & & & & & & & & & 54 & 6 & 1 & & 4 & & 87 \\
\hline & Corn & 20 & 29 & & 1 & 58 & 8 & 1 & 6 & & & & & 28 & 5 & & & & & & 1 & 205 & 30 & 8 & 3 & 5 & 408 \\
\hline & Tomatoes & 6 & 12 & & & 96 & 8 & 2 & 1 & & & & & 15 & 1 & 3 & & 3 & & & & 22 & 316 & 5 & 36 & 11 & 537 \\
\hline & Walnuts & 2 & 127 & & 1 & 8 & 1 & 3 & 8 & 1 & & 1 & & 32 & 31 & 5 & & 1 & & & & & & 85 & & 4 & 310 \\
\hline & Watermelons & 1 & 2 & & 2 & 8 & 9 & & 1 & & & & & 6 & 1 & & & & & & & & 17 & 3 & 60 & & 110 \\
\hline & Grand Total & 1523 & 2904 & 5 & 37 & 1554 & 84 & 136 & 318 & 80 & 0 & 11 & 0 & 1302 & 356 & 118 & 20 & 49 & 0 & 0 & 79 & 313 & 502 & 313 & 144 & 111 & 9959 \\
\hline
\end{tabular}


2011 Confusion Matrix - Utilizing 10\% of DWR ground survey data from 2011.

\begin{tabular}{|c|c|c|c|c|c|c|c|c|c|c|c|c|c|c|c|c|c|c|c|c|c|c|c|c|c|c|c|}
\hline & & & \multicolumn{25}{|c|}{ User Classification } \\
\hline & Crop Type & $\frac{\frac{\pi}{\pi}}{\frac{\pi}{\pi}}$ & $\begin{array}{l}\overline{0} \\
\bar{c} \\
\stackrel{\xi}{\tau} \\
\frac{\xi}{\alpha}\end{array}$ & $\frac{\tilde{e}}{\frac{0}{2}}$ & 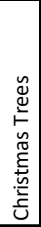 & $\begin{array}{l}0 \\
0 \\
0 \\
0 \\
0\end{array}$ & $\begin{array}{l}\simeq \\
\check{J} \\
\Xi \\
\infty \\
\geq \\
\vdots\end{array}$ & 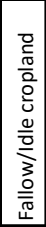 & $\begin{array}{l}\widetilde{\Xi} \\
\frac{0}{\pi} \\
\frac{0}{0}\end{array}$ & 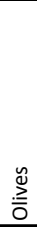 & 气 & 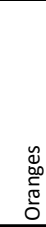 & 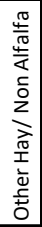 & 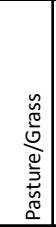 & 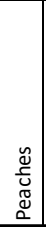 & 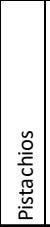 & $\frac{\tilde{\xi}}{\frac{3}{a}}$ & \begin{tabular}{l}
$\tilde{y}$ \\
$\stackrel{2}{2}$ \\
\multirow{2}{2}{}
\end{tabular} & 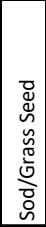 & 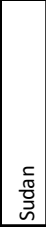 & 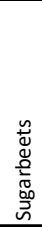 & ¿ & \begin{tabular}{l}
$\tilde{y}$ \\
0 \\
0 \\
\multirow{0}{0}{} \\
$\varepsilon$ \\
0 \\
$\circ$
\end{tabular} & $\begin{array}{l}\frac{n}{5} \\
\frac{5}{\pi} \\
3\end{array}$ & 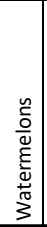 & 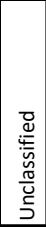 & $\begin{array}{l}\bar{\pi} \\
0 \\
0 \\
0 \\
0 \\
0 \\
0\end{array}$ \\
\hline \multirow{25}{*}{ 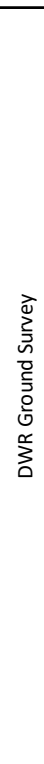 } & Alfalfa & 384 & 20 & 2 & 1 & & & 4 & 37 & & & & & 36 & & 10 & & & & & & 1 & 2 & & & & 497 \\
\hline & Almond & 6 & 1712 & 8 & 2 & 33 & & 23 & 97 & & 2 & 22 & & 10 & 4 & 141 & & 7 & & & & 1 & & 1 & & 10 & 2079 \\
\hline & Apples & 4 & 22 & 9 & & 4 & & 7 & 9 & & & & & & 1 & 4 & & & & & & 1 & & 2 & & 3 & 66 \\
\hline & Christmas Trees & & 5 & & 2 & 3 & & & 5 & & & & & & & 2 & & 2 & & & & & & & & 5 & 24 \\
\hline & Cotton & 3 & 19 & 6 & 4 & 142 & & 14 & 22 & & 2 & & & 3 & 1 & 12 & & 1 & & & & & 2 & 2 & & 2 & 235 \\
\hline & \begin{tabular}{|l|} 
Dry Beans \\
\end{tabular} & & 1 & & & 9 & & & 7 & & & & & & & & & & & & & 5 & 2 & & & & 24 \\
\hline & Fallow/Idle cropland & 3 & 9 & 11 & & 17 & & 56 & 10 & & 2 & & & 6 & 9 & 17 & & & & & & 2 & & 12 & & & 154 \\
\hline & Grapes & 6 & 208 & 10 & 8 & 12 & & 17 & 1290 & 1 & 1 & 11 & & 9 & 18 & 47 & & 12 & & & & & & 8 & & 25 & 1683 \\
\hline & \begin{tabular}{|l|} 
Olives \\
\end{tabular} & & 11 & 11 & 3 & 1 & & 2 & 5 & 1 & & 1 & & & & 11 & & 1 & & & & & & & & 2 & 49 \\
\hline & Onions & & 1 & & 1 & & & 1 & & & 1 & & & & & & & & & & & & & & & & 4 \\
\hline & Oranges & & 28 & 2 & 1 & 1 & & 2 & 15 & & & 77 & & & 1 & 21 & & & & & & & & & & 4 & 152 \\
\hline & Other Hay/ Non Alfalfa & 23 & 42 & & 1 & 5 & & 11 & 31 & 1 & & 3 & & 66 & 1 & 14 & & & & & & 1 & & 3 & & 17 & 219 \\
\hline & \begin{tabular}{|l|} 
Pasture/Grass \\
\end{tabular} & & 12 & 2 & & & & 1 & 7 & & & 1 & & 16 & & & 7 & & & & & & & 1 & & 2 & 49 \\
\hline & Peaches & & 1 & & & & & & & & & & & & & & & & & & & & & & & & 1 \\
\hline & \begin{tabular}{|l} 
Pistachios \\
\end{tabular} & 3 & 38 & 5 & 4 & 20 & & 20 & 26 & & 1 & 27 & & & 1 & 262 & & & & & & & & 2 & & 11 & 420 \\
\hline & Plums & & 7 & & & 1 & & & 2 & & & & & & 2 & & 7 & 1 & & & & & & & & & 20 \\
\hline & \begin{tabular}{|l|} 
Prunes \\
\end{tabular} & & 7 & & & 1 & & & & & & & & & & 1 & 4 & 6 & & & & & & & & 1 & 20 \\
\hline & Sod/Grass Seed & & & & & & & & & & & & & & & & & & & & & & & & & & 0 \\
\hline & \begin{tabular}{|l|} 
Sudan \\
\end{tabular} & & & & & & & & & & & & & & & & & & & & & & & & & & 0 \\
\hline & \begin{tabular}{|l} 
Sugarbeets \\
\end{tabular} & & & & & & & & & & & & & & & & & & & & & & & & & & 0 \\
\hline & \begin{tabular}{|l|} 
Corn \\
\end{tabular} & 3 & 6 & & & 7 & & & 13 & & 1 & & & & 1 & 2 & & & & & & 87 & 4 & & & 5 & 129 \\
\hline & Tomatoes & & 1 & & & 1 & & & 3 & & & & & & & & & & & & & 6 & 36 & & & 5 & 52 \\
\hline & \begin{tabular}{|l|} 
Walnuts \\
\end{tabular} & 3 & 18 & 1 & & 1 & & 1 & 5 & & 1 & & & & 3 & 4 & 1 & & & & & & & 9 & & 1 & 48 \\
\hline & Watermelons & & 1 & & 1 & & & & 5 & & 1 & & & & & 1 & & & & & & & & & & 1 & 10 \\
\hline & Grand Total & 438 & 2169 & 67 & 28 & 258 & 0 & 159 & 1589 & 3 & 12 & 142 & 0 & 146 & 42 & 549 & 19 & 30 & 0 & 0 & 0 & 104 & 46 & 40 & 0 & 94 & 5935 \\
\hline
\end{tabular}


2001 Confusion Matrix - Utilizing 20\% of DWR ground survey data from 2001.

\begin{tabular}{|c|c|c|c|c|c|c|c|c|c|c|c|c|c|c|c|c|c|c|c|c|c|c|c|c|c|c|c|}
\hline & & & \multicolumn{25}{|c|}{ User Classification } \\
\hline & Crop Type & $\begin{array}{l}\frac{\pi}{\pi} \\
\frac{\pi}{4} \\
\end{array}$ & 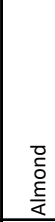 & $\frac{\tilde{d}}{\frac{0}{2}}$ & 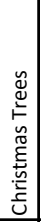 & $\begin{array}{l}5 \\
0 \\
0 \\
0 \\
0\end{array}$ & 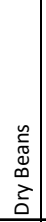 & 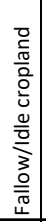 & $\begin{array}{l}\tilde{\Xi} \\
\frac{0}{\pi} \\
\frac{\pi}{0}\end{array}$ & 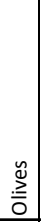 & 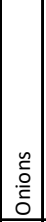 & 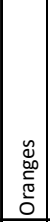 & 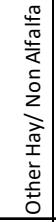 & 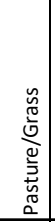 & 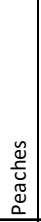 & 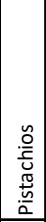 & $\begin{array}{l}\hat{\xi} \\
\frac{\hat{J}}{\alpha} \\
\end{array}$ & \begin{tabular}{|l|}
0 \\
$\stackrel{2}{2}$ \\
2 \\
2 \\
2
\end{tabular} & 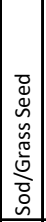 & \begin{tabular}{l} 
\\
\multicolumn{1}{c}{} \\
$\frac{\pi}{0}$ \\
$\tilde{n}$ \\
\end{tabular} & 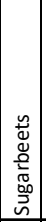 & $\begin{array}{l}5 \\
0 \\
0\end{array}$ & 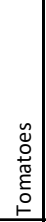 & $\begin{array}{l}\frac{n}{\vec{J}} \\
\frac{c}{n} \\
3 \\
3\end{array}$ & 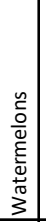 & 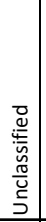 & 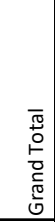 \\
\hline \multirow{25}{*}{ 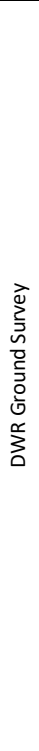 } & Alfalfa & 588 & 10 & & & 5 & & 1 & 36 & & & 1 & 9 & 28 & & & & & 2 & 1 & & & & & & 1 & 682 \\
\hline & Almond & & 1261 & 6 & 1 & 2 & & 9 & 92 & 5 & & 12 & 13 & 16 & 4 & 44 & 9 & 3 & & & & & & 3 & 4 & 3 & 1487 \\
\hline & Apples & 1 & 14 & 35 & & & & & 8 & 1 & & 6 & & & 1 & 4 & 2 & & & & & & & 1 & & & 73 \\
\hline & Christmas Trees & & 2 & 1 & 8 & & & & 6 & 2 & & 1 & & 1 & & 3 & 1 & & & & & & & & & & 25 \\
\hline & Cotton & 9 & 2 & & & 433 & & 1 & 7 & 1 & & & 1 & & & & & & & & & 12 & & & & & 466 \\
\hline & Dry Beans & & & & & & 5 & & & & & & & & & & & & & & & 4 & & & & 1 & 10 \\
\hline & Fallow/Idle cropland & 1 & 9 & & & & & 32 & 15 & & & & 23 & 15 & & 5 & 2 & & & & 2 & 1 & & 1 & 1 & 1 & 108 \\
\hline & Grapes & 11 & 107 & 17 & & & & 12 & 2894 & 2 & & 16 & 11 & 28 & 10 & 51 & 27 & 1 & & & 1 & 5 & 1 & 3 & 2 & 19 & 3218 \\
\hline & Olives & & 3 & & & & & & 2 & 27 & & & 1 & 2 & & 7 & & & & & & & & & & & 42 \\
\hline & Onions & & & & & & & & & & 7 & & 2 & & & & & & & & & 1 & & & & & 10 \\
\hline & Oranges & & 15 & 2 & & & & & 12 & 6 & & 89 & 3 & 5 & & 19 & 1 & & 1 & & & & & & & & 153 \\
\hline & Other Hay/ Non Alfalfa & 8 & 8 & 1 & & 1 & & 18 & 21 & & 3 & 2 & 295 & 30 & & 6 & & & & & & 4 & & & & 2 & 399 \\
\hline & \begin{tabular}{|l|} 
Pasture/Grass \\
\end{tabular} & 8 & 35 & 6 & & 1 & & 18 & 37 & 2 & & 5 & 38 & 197 & 1 & 11 & 3 & & 8 & & & & & 7 & 1 & 5 & 383 \\
\hline & Peaches & & 20 & 5 & 1 & & & & 33 & 3 & & 5 & & 5 & 48 & 7 & 13 & & & & 1 & 1 & & & 1 & & 143 \\
\hline & \begin{tabular}{|l|} 
Pistachios \\
\end{tabular} & & 22 & 1 & & & & 1 & 10 & 6 & & 6 & 14 & 9 & & 351 & 3 & & & & & & & 3 & & 2 & 428 \\
\hline & Plums & & 15 & 3 & & & & & 15 & 1 & & 5 & & 2 & 3 & 14 & 52 & 2 & & & & & & & & 3 & 115 \\
\hline & Prunes & & 16 & 2 & & & & & 6 & & & & & & 1 & 1 & 3 & 8 & & & & & & & & & 37 \\
\hline & Sod/Grass Seed & 1 & 2 & 1 & & & & 1 & 10 & & & 2 & & 1 & & 12 & & & 6 & & & & & & & 1 & 37 \\
\hline & \begin{tabular}{|l} 
Sudan \\
\end{tabular} & 2 & & & & & & & 4 & & & & 2 & 3 & & 1 & & & & 26 & & 2 & & & & & 40 \\
\hline & Sugarbeets & & 2 & & & 3 & & & 2 & & & & & 1 & & & & & & & 4 & 1 & & & & & 13 \\
\hline & Corn & & 4 & & & 12 & & & 27 & 1 & & & 5 & 4 & & & & & & & & 322 & 3 & 1 & & 4 & 383 \\
\hline & \begin{tabular}{|l} 
Tomatoes \\
\end{tabular} & & & 1 & & 3 & & & 7 & & & & & & & & & & & & & 17 & 13 & & & & 41 \\
\hline & Walnuts & & 14 & 1 & & & & & 4 & 1 & & & & 2 & & 16 & 4 & & & & 1 & & & 8 & & 1 & 52 \\
\hline & Watermelons & 1 & 1 & & & & & & 3 & & & & 1 & & & & & & & & 1 & & 1 & & 4 & 1 & 13 \\
\hline & Grand Total & 630 & 1562 & 82 & 10 & 460 & 5 & 93 & 3251 & 58 & 10 & 150 & 418 & 349 & 68 & 552 & 120 & 14 & 17 & 27 & 10 & 370 & 18 & 27 & 13 & 44 & 8358 \\
\hline
\end{tabular}


2002 Merced Confusion Matrix - Utilizing 20\% of DWR ground survey data from 2002 Merced.

\begin{tabular}{|c|c|c|c|c|c|c|c|c|c|c|c|c|c|c|c|c|c|c|c|c|c|c|c|c|c|c|c|}
\hline & & & \multicolumn{25}{|c|}{ User Classification } \\
\hline & Crop Type & $\begin{array}{l}\frac{\pi}{4} \\
\frac{\pi}{4} \\
\end{array}$ & 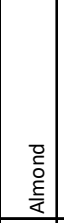 & $\frac{\tilde{u}}{\frac{a}{2}}$ & 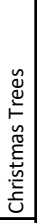 & 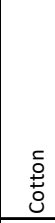 & 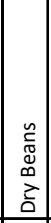 & 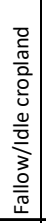 & $\begin{array}{l}\widetilde{\Xi} \\
\frac{0}{\pi} \\
\frac{\pi}{0}\end{array}$ & 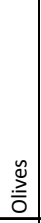 & 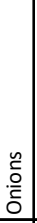 & 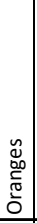 & 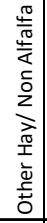 & 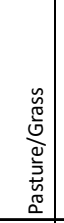 & 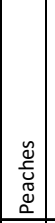 & 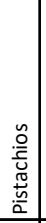 & $\begin{array}{l}\tilde{y} \\
\frac{\tilde{J}}{a} \\
\end{array}$ & $\begin{array}{l}\tilde{y} \\
\stackrel{5}{2} \\
2\end{array}$ & 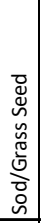 & \begin{tabular}{l|}
$\frac{c}{0}$ \\
$\frac{\pi}{0}$ \\
n \\
\end{tabular} & 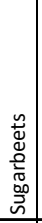 & $\begin{array}{l}5 \\
0 \\
\end{array}$ & 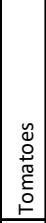 & $\begin{array}{l}\frac{n}{3} \\
\frac{5}{n} \\
3 \\
3\end{array}$ & 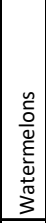 & 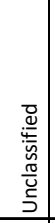 & 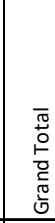 \\
\hline \multirow{25}{*}{ 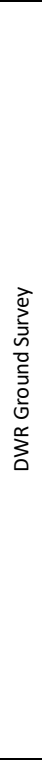 } & Alfalfa & 1489 & 56 & & 1 & 37 & 21 & 5 & 8 & & & 1 & & 118 & 9 & 2 & 2 & & & & 3 & 22 & 14 & 7 & 4 & 11 & 1810 \\
\hline & Almond & 13 & 2395 & 3 & 4 & 39 & & 13 & 39 & & & & & 73 & 74 & 17 & 7 & 1 & & & & 9 & 4 & 50 & & 33 & 2774 \\
\hline & Apples & & 9 & 1 & 2 & 3 & & 1 & 1 & & & & & & & & & & & & & & & 1 & & 0 & 18 \\
\hline & Christmas Trees & & 13 & & 15 & 1 & & & 2 & 3 & & & & 1 & 1 & 5 & 1 & & & & & 1 & & 1 & & 3 & 47 \\
\hline & Cotton & 35 & 69 & & 6 & 1201 & 15 & 19 & 11 & 4 & & & & 37 & 6 & 6 & 1 & & & & 3 & 9 & 52 & 7 & 10 & 12 & 1503 \\
\hline & Dry Beans & 1 & & & 2 & & 13 & 2 & 1 & & & & & & 2 & & & & & & & & & & & & 21 \\
\hline & Fallow/Idle cropland & & 3 & & & 10 & 67 & 16 & 2 & & & & & 2 & 2 & & & & & & & 7 & 11 & & 4 & 1 & 125 \\
\hline & Grapes & 5 & 9 & & 1 & 4 & & 7 & 66 & 1 & & & & 3 & 2 & 3 & & & & & 1 & 1 & & 2 & 1 & 2 & 108 \\
\hline & Olives & 5 & 47 & & 1 & 3 & 1 & 3 & 144 & 37 & & & & 33 & 29 & 2 & & & & & & 1 & & 7 & & 6 & 319 \\
\hline & Onions & 1 & & & & & & & & 1 & & & & & & & & & & & & & & 1 & & 0 & 3 \\
\hline & Oranges & & & & & & & & & & & 1 & & & & & & & & & & & & & & 3 & 4 \\
\hline & Other Hay/ Non Alfalfa & & 2 & & & & & & & & & 1 & & & & & & & & & & & & & & 0 & 3 \\
\hline & Pasture/Grass & 83 & 172 & & 2 & 24 & 1 & 10 & 18 & & & & & 851 & 41 & 6 & 2 & & & & & 8 & 5 & 29 & 4 & 13 & 1269 \\
\hline & Peaches & 1 & 44 & 1 & & 3 & & 4 & 12 & & & & & 4 & 242 & 1 & 4 & & & & & 1 & & 29 & & 5 & 351 \\
\hline & Pistachios & & & & & & & & & & & & & & 1 & & & & & & & & & & & 0 & 1 \\
\hline & Plums & & & & & 1 & & & & & & & & & & & 1 & & & & & & 2 & & & 0 & 4 \\
\hline & Prunes & 4 & 26 & & & & & & & & & & & 1 & 1 & & & 39 & & & & & & 5 & & 1 & 77 \\
\hline & Sod/Grass Seed & & 5 & & & 1 & & & & & & & & 1 & 6 & 2 & 8 & 7 & & & & 1 & & 4 & 1 & 0 & 36 \\
\hline & Sudan & 1 & 10 & & 1 & & & & & & & & & & & & & 22 & & & & & & & & 0 & 34 \\
\hline & Sugarbeets & & 3 & & & 16 & 2 & & & 1 & & & & 3 & & & & & & & 62 & & & & & 0 & 87 \\
\hline & Corn & 15 & 22 & & & 43 & 5 & & 5 & & & & & 14 & 5 & 1 & 2 & & & & 1 & 263 & 18 & 6 & 4 & 4 & 408 \\
\hline & Tomatoes & 13 & 4 & & 2 & 99 & 3 & 4 & 1 & & & & & 9 & 1 & 1 & & & & & & 21 & 357 & 2 & 9 & 11 & 537 \\
\hline & Walnuts & 4 & 97 & & 2 & 11 & & 3 & 8 & & & & & 14 & \begin{tabular}{|l|}
49 \\
\end{tabular} & 2 & 3 & 1 & & & & 4 & 1 & 106 & 1 & 4 & 310 \\
\hline & Watermelons & & 4 & & & 8 & 6 & & 2 & & & & & 7 & 1 & & & & & & & 3 & 12 & & 67 & 0 & 110 \\
\hline & Grand Total & 1670 & 2990 & 5 & 39 & 1504 & 134 & 87 & 320 & 47 & 0 & 3 & 0 & 1171 & 472 & 48 & 31 & 70 & 0 & 0 & 70 & 351 & 476 & 257 & 105 & 109 & 9959 \\
\hline
\end{tabular}


2011 Confusion Matrix - Utilizing 20\% of DWR ground survey data from 2011.

\begin{tabular}{|c|c|c|c|c|c|c|c|c|c|c|c|c|c|c|c|c|c|c|c|c|c|c|c|c|c|c|c|}
\hline & & & \multicolumn{25}{|c|}{ User Classification } \\
\hline & Crop Type & $\begin{array}{l}\frac{\pi}{\pi} \\
\frac{\pi}{\pi}\end{array}$ & $\begin{array}{l}\overline{0} \\
\stackrel{0}{0} \\
\frac{E}{<}\end{array}$ & $\frac{\tilde{u}}{\frac{0}{0}}$ & 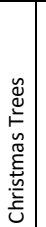 & \begin{tabular}{l}
5 \\
0 \\
\multirow{+}{0}{} \\
0
\end{tabular} & 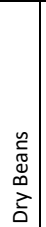 & $\begin{array}{l}\overline{0} \\
\frac{0}{0} \\
\frac{\pi}{0} \\
\frac{0}{U} \\
\frac{0}{0} \\
\frac{0}{3} \\
\frac{0}{\bar{T}} \\
\overline{4}\end{array}$ & $\begin{array}{l}\tilde{\Xi} \\
\frac{0}{0} \\
\mathbb{0}\end{array}$ & 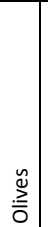 & $\begin{array}{l}\tilde{c} \\
\stackrel{0}{\check{L}} \\
0\end{array}$ & $\begin{array}{l}\tilde{d} \\
0 \\
0 \\
0 \\
0 \\
0\end{array}$ & 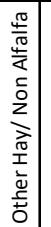 & 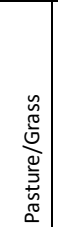 & $\begin{array}{l}\tilde{d} \\
\stackrel{d}{U} \\
\tilde{\Xi} \\
\tilde{d}\end{array}$ & 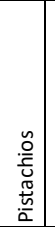 & $\begin{array}{l}\underline{\underline{\xi}} \\
\frac{3}{\alpha}\end{array}$ & 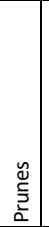 & 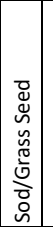 & $\begin{array}{l}\frac{c}{1} \\
\frac{\pi}{0} \\
\stackrel{3}{n}\end{array}$ & 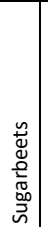 & c & 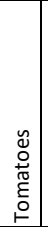 & $\begin{array}{l}\frac{n}{5} \\
\frac{c}{n} \\
3 \\
3\end{array}$ & 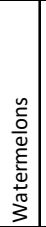 & 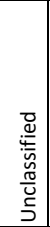 & 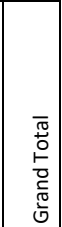 \\
\hline \multirow{25}{*}{ 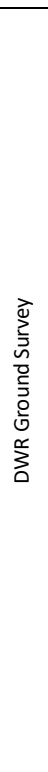 } & Alfalfa & 417 & 26 & 2 & & 2 & & 5 & 17 & 1 & & & & 22 & & 2 & & & & & & & & & 1 & 2 & 497 \\
\hline & Almond & 2 & 1818 & 5 & 3 & 10 & & 20 & 69 & 11 & & 9 & & 4 & 5 & 88 & 6 & & & & & & & 5 & & 24 & 2079 \\
\hline & Apples & 1 & 10 & 18 & & 2 & & 8 & 13 & 1 & & 1 & & & 3 & 4 & & & & & & & & 2 & & 3 & 66 \\
\hline & Christmas Trees & & 2 & & 4 & & & & 8 & 2 & & & & & 2 & 1 & & & & & & & & & & 5 & 24 \\
\hline & Cotton & 2 & 33 & 5 & & 134 & & 14 & 25 & 6 & & & & 3 & & 8 & & & & & & 2 & & & & 3 & 235 \\
\hline & Dry Beans & & & & & & 21 & & 2 & & & & & & & & & & & & & & 1 & & & & 24 \\
\hline & Fallow/Idle cropland & 10 & 18 & 7 & & 9 & & 53 & 25 & 6 & & & & 8 & & 12 & & & & & & & & 3 & & 3 & 154 \\
\hline & Grapes & 2 & 143 & 3 & 4 & 7 & & 16 & \begin{tabular}{l|l}
1398 \\
\end{tabular} & 5 & & 9 & & 9 & 1 & 39 & & 1 & & & & & & 3 & 1 & 42 & 1683 \\
\hline & Olives & & 6 & 1 & & 1 & & & 6 & 22 & & 1 & & & & 9 & & & & & & & & & & 3 & 49 \\
\hline & \begin{tabular}{|l|} 
Onions \\
\end{tabular} & & 1 & & & & & 1 & & & 2 & & & & & & & & & & & & & & & & 4 \\
\hline & Oranges & & 36 & & 1 & & & 1 & 7 & & & 85 & & & & 18 & & & & & & & & & & 4 & 152 \\
\hline & Other Hay/ Non Alfalfa & 13 & 39 & 1 & 1 & & & 5 & 19 & 1 & & & & 113 & & 9 & & & & & & & & 1 & & 17 & 219 \\
\hline & Pasture/Grass & & 6 & & & & & 2 & 7 & & & 1 & & 25 & & 1 & 1 & & & & & & & 4 & & 2 & 49 \\
\hline & \begin{tabular}{|l|} 
Peaches \\
\end{tabular} & & 1 & & & & & & & & & & & & & & & & & & & & & & & & 1 \\
\hline & \begin{tabular}{|l|} 
Pistachios \\
\end{tabular} & 1 & 61 & 1 & & 7 & & 11 & 16 & 4 & & 7 & & 3 & 1 & 295 & 1 & & & & & & & & & 12 & 420 \\
\hline & \begin{tabular}{|l|} 
Plums \\
\end{tabular} & & 4 & & & 1 & & & & 1 & & & & & 5 & 1 & 7 & 1 & & & & & & & & & 20 \\
\hline & Prunes & & 12 & & & & & & 1 & & & & & & & & & 5 & & & & & & 1 & & 1 & 20 \\
\hline & Sod/Grass Seed & & & & & & & & & & & & & & & & & & & & & & & & & & 0 \\
\hline & Sudan & & & & & & & & & & & & & & & & & & & & & & & & & & 0 \\
\hline & Sugarbeets & & & & & & & & & & & & & & & & & & & & & & & & & & 0 \\
\hline & Corn & 3 & 8 & & & 9 & 3 & 1 & 13 & & & & & 1 & 1 & 4 & & & & & & 80 & 1 & & & 5 & 129 \\
\hline & \begin{tabular}{|l|} 
Tomatoes \\
\end{tabular} & 1 & 1 & & & 4 & 1 & & 4 & & & & & & & & & & & & & 2 & 36 & & 1 & 2 & 52 \\
\hline & \begin{tabular}{|l|} 
Walnuts \\
\end{tabular} & & 8 & 1 & & & & 1 & 6 & & & & & 1 & 3 & 6 & & & & & & & & 21 & & 1 & 48 \\
\hline & Watermelons & & 3 & & & & & & 2 & & & & & & & & & & & & & & & & 4 & 1 & 10 \\
\hline & Grand Total & 452 & 2236 & 44 & 13 & 186 & 25 & 138 & \begin{tabular}{|l|l|}
1638 \\
\end{tabular} & 60 & 2 & 113 & 0 & 189 & 21 & \begin{tabular}{|l|}
497 \\
\end{tabular} & 15 & 7 & 0 & 0 & 0 & 84 & 38 & 40 & 7 & 130 & 5935 \\
\hline
\end{tabular}


2002 Merced Confusion Matrix - Utilizing 90\% of DWR ground survey data from 2001.

\begin{tabular}{|c|c|c|c|c|c|c|c|c|c|c|c|c|c|c|c|c|c|c|c|c|c|c|c|c|c|c|c|}
\hline & & & \multicolumn{25}{|c|}{ User Classification } \\
\hline & Crop Type & $\begin{array}{l}\frac{\pi}{\sqrt{5}} \\
\frac{\pi}{4}\end{array}$ & $\begin{array}{l}\overline{0} \\
\text { ○े } \\
\text { हे }\end{array}$ & $\frac{\tilde{c}}{\frac{0}{2}}$ & 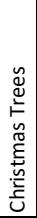 & $\begin{array}{l}5 \\
0 \\
\pm \\
0\end{array}$ & $\begin{array}{l}n \\
\check{D} \\
\mathbb{\Xi} \\
\infty \\
\geq \\
\vdots\end{array}$ & $\begin{array}{l}\overline{0} \\
\frac{0}{0} \\
\frac{0}{0} \\
\frac{0}{0} \\
\frac{0}{0} \\
\frac{0}{3} \\
\frac{0}{\bar{\sigma}} \\
\overline{5}\end{array}$ & $\begin{array}{l}\breve{\Xi} \\
\frac{0}{\pi} \\
\stackrel{0}{0}\end{array}$ & $\stackrel{\varrho}{\stackrel{\Xi}{0}}$ & 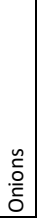 & 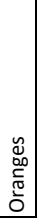 & 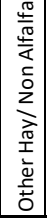 & 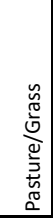 & 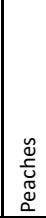 & 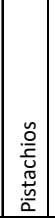 & $\frac{\mathfrak{\xi}}{\frac{\xi}{\alpha}}$ & 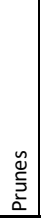 & 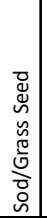 & 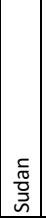 & 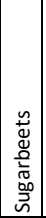 & క & 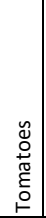 & $\begin{array}{l}0 \\
5 \\
\frac{c}{n \pi} \\
3 \\
3\end{array}$ & $\begin{array}{l}\frac{n}{0} \\
\frac{0}{U} \\
\frac{5}{0} \\
\frac{ \pm}{\pi} \\
3\end{array}$ & 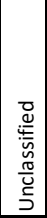 & $\begin{array}{l}\bar{\pi} \\
\stackrel{0}{0} \\
\circ \\
0 \\
\frac{0}{\pi} \\
\frac{0}{0}\end{array}$ \\
\hline \multirow{25}{*}{ 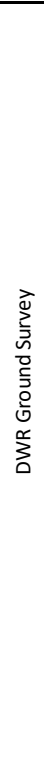 } & Alfalfa & 1391 & 103 & 4 & 6 & 27 & & 1 & 133 & 3 & 1 & 4 & 20 & 73 & 1 & 7 & 8 & & 1 & 3 & & 17 & 3 & 3 & 1 & & 1810 \\
\hline & Almond & 23 & 2268 & 7 & 7 & 3 & & 6 & 299 & 4 & & 9 & 15 & 37 & 7 & 60 & 5 & 2 & 3 & & 1 & 4 & 1 & 12 & 1 & & 2774 \\
\hline & Apples & & 7 & & & 1 & & 2 & 5 & & & & 1 & 1 & & 1 & & & & & & & & & & & 18 \\
\hline & Christmas Trees & 1 & 7 & 1 & 4 & & & & 20 & 1 & & 1 & 3 & & & 4 & 1 & & 1 & & & & & 1 & & 2 & 47 \\
\hline & Cotton & 22 & 132 & 2 & 19 & 872 & 2 & 19 & 220 & 15 & & 7 & 78 & 42 & 3 & 13 & 6 & 2 & & & 1 & 21 & 8 & 7 & 12 & & 1503 \\
\hline & Dry Beans & 1 & & & 2 & & 13 & 2 & 1 & & & & & & 2 & & & & & & & & & & & & 21 \\
\hline & Fallow/Idle cropland & 1 & 36 & & & & 1 & 9 & 30 & 1 & & 1 & 14 & 6 & & 5 & & 2 & 2 & & & 2 & & 2 & & 13 & 125 \\
\hline & Grapes & 10 & 8 & 1 & & & & & 68 & & & 1 & 6 & 5 & & 7 & & & 1 & & & & & & 1 & & 108 \\
\hline & Olives & 5 & 53 & & 1 & & 1 & 3 & 144 & 37 & & & & 30 & 29 & 2 & & & & & & 1 & & 7 & 6 & & 319 \\
\hline & Onions & & & & & & & & & & & & & & & & & & & & & 1 & & & & 2 & 3 \\
\hline & Oranges & 1 & 1 & & & & & & & & & & & & & & & & & & & & & 1 & & 1 & 4 \\
\hline & Other Hay/ Non Alfalfa & & & & & & & & & & & & & & & & & & & & & & & & & 3 & 3 \\
\hline & Pasture/Grass & 204 & 371 & 7 & 3 & 4 & & 4 & 176 & 3 & & & 27 & 404 & 2 & 19 & & 11 & 12 & 2 & & 7 & & 12 & 1 & & 1269 \\
\hline & Peaches & 5 & 105 & 11 & & & & 1 & 121 & 2 & & 1 & 3 & 4 & 72 & 2 & 22 & 1 & & & & 1 & & & & & 351 \\
\hline & \begin{tabular}{|l|} 
Pistachios \\
\end{tabular} & & & & & & & & & & & & & & 1 & & & & & & & & & & & & 1 \\
\hline & Plums & & & & & & & & & 2 & & & & & & & 1 & & & & & & & & & 1 & 4 \\
\hline & Prunes & & 10 & & & & 8 & & 15 & 1 & & 13 & & & & 8 & & & & 15 & & & & & & 7 & 77 \\
\hline & Sod/Grass Seed & & 5 & & & 1 & & & & & & & & 1 & 6 & 2 & 8 & 7 & & & & 1 & & 4 & 1 & & 36 \\
\hline & Sudan & 1 & 10 & & 1 & & & & & & & & & & & & & 22 & & & & & & & & & 34 \\
\hline & Sugarbeets & 2 & 11 & & 1 & 10 & & & 22 & 3 & & & 2 & 1 & & 18 & & & 8 & & 9 & & & & & & 87 \\
\hline & Corn & 27 & 44 & & 2 & 22 & 2 & & 61 & 1 & & 1 & 14 & 18 & 2 & 8 & 5 & 1 & 1 & 4 & & 186 & 6 & 1 & & 2 & 408 \\
\hline & Tomatoes & 14 & 48 & 2 & 13 & 104 & 3 & 1 & 176 & 4 & 3 & & 14 & 15 & 1 & 28 & 5 & 1 & 5 & & & 67 & 17 & 5 & 11 & & 537 \\
\hline & Walnuts & 4 & 172 & 11 & 1 & & & 1 & 73 & 2 & & 2 & 3 & 3 & 20 & 9 & 7 & & & & & & & 2 & & & 310 \\
\hline & Watermelons & 5 & 20 & & 1 & 18 & & 1 & 34 & 2 & & & 1 & & & 2 & 1 & & & 3 & & 15 & 6 & & 1 & & 110 \\
\hline & Grand Total & 1717 & 3411 & 46 & 61 & 1062 & 30 & 50 & 1598 & 81 & 4 & 40 & 201 & 640 & 146 & 195 & 69 & 49 & 34 & 27 & \begin{tabular}{|c|}
11 \\
\end{tabular} & 323 & 41 & 57 & 35 & 31 & 9959 \\
\hline
\end{tabular}


2011 Confusion Matrix - Utilizing 90\% of DWR ground survey data from 2001.

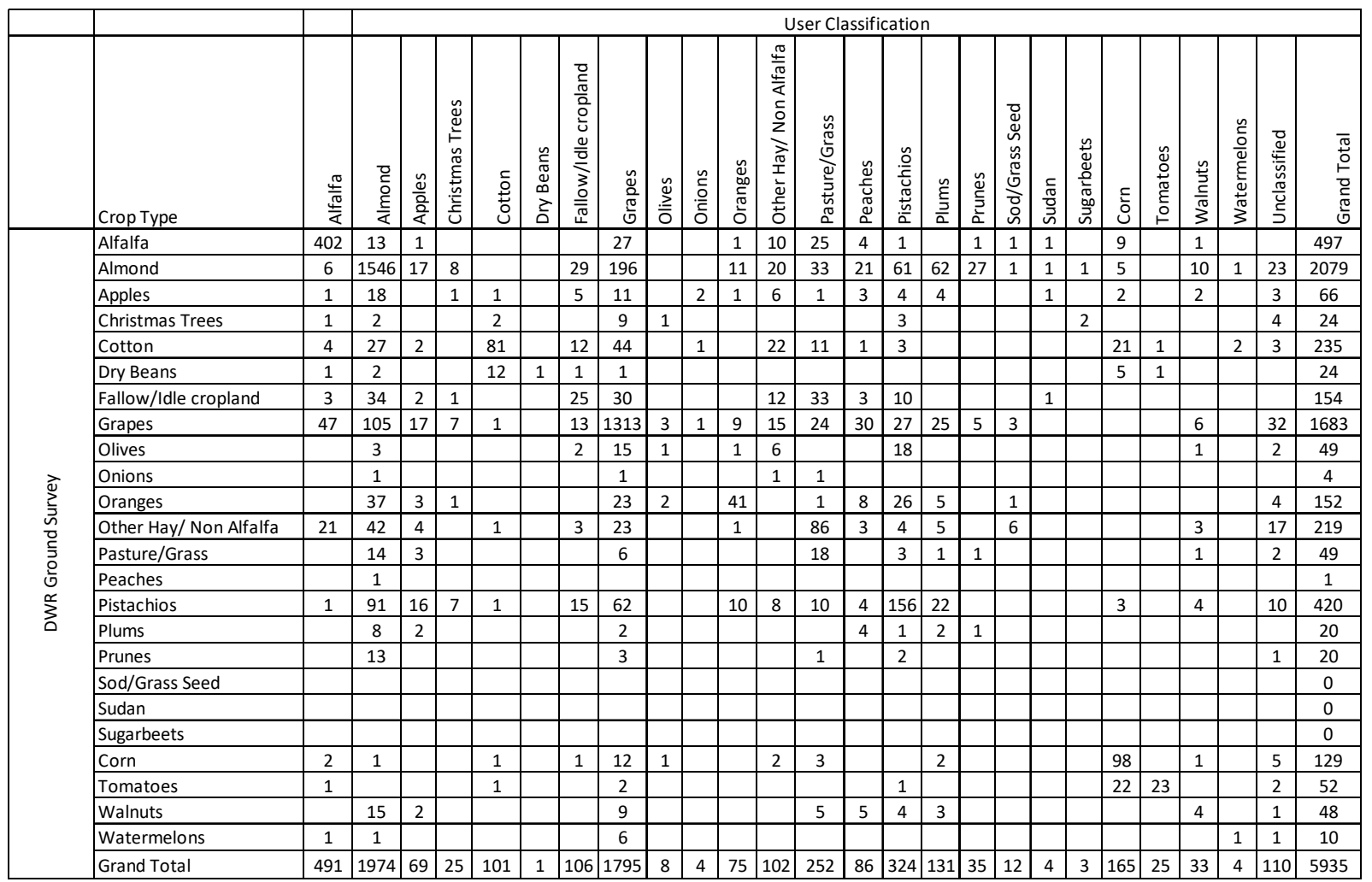


2002 Merced Confusion Matrix - Utilizing 90\% of DWR ground survey data from 2001 plus 10\% 2002 Merced DWR ground survey added to the Training Data set.

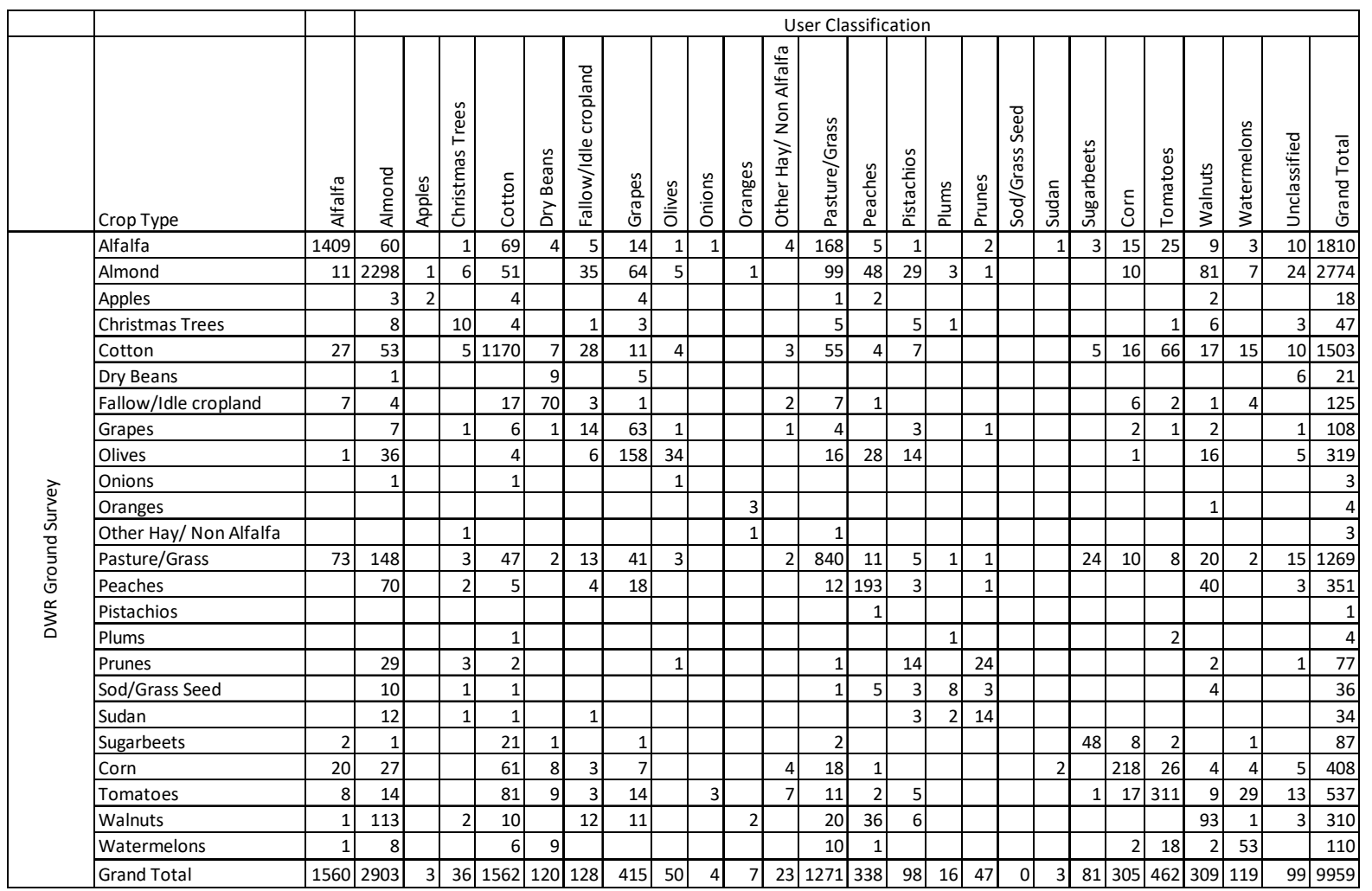


2011 Confusion Matrix - Utilizing 90\% of DWR ground survey data from 2001 plus 10\% 2011 DWR ground survey added to the Training Data set.

\begin{tabular}{|c|c|c|c|c|c|c|c|c|c|c|c|c|c|c|c|c|c|c|c|c|c|c|c|c|c|c|c|}
\hline & & & \multicolumn{25}{|c|}{ User Classification } \\
\hline & Crop Type & $\begin{array}{l}\frac{\pi}{\pi} \\
\frac{4}{4} \\
\end{array}$ & 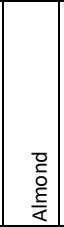 & $\frac{\tilde{u}}{\frac{0}{2}}$ & 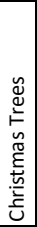 & $\begin{array}{l}5 \\
0 \\
\pm \\
0\end{array}$ & 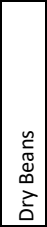 & 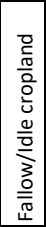 & $\begin{array}{l}\tilde{0} \\
\frac{0}{0} \\
\frac{0}{0}\end{array}$ & $\stackrel{\mathscr{y}}{\stackrel{\check{0}}{0}}$ & 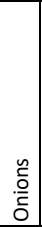 & $\begin{array}{l}\tilde{\Xi} \\
0 \\
\tilde{0} \\
\tilde{0} \\
\tilde{0}\end{array}$ & 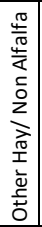 & 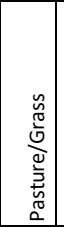 & $\begin{array}{l}\tilde{g} \\
\stackrel{\tilde{U}}{ } \\
\mathbb{\Xi} \\
\mathbb{\Xi}\end{array}$ & 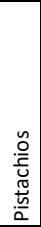 & $\frac{\tilde{\xi}}{\frac{\tilde{J}}{\alpha}}$ & 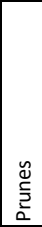 & 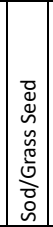 & $\begin{array}{l}\frac{c}{0} \\
\frac{\pi}{0} \\
\sim \\
\sim\end{array}$ & 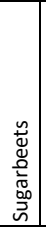 & छั & 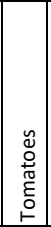 & 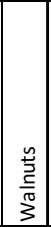 & 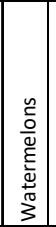 & 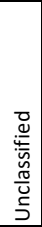 & 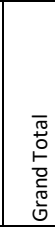 \\
\hline \multirow{25}{*}{ 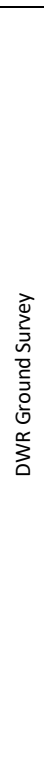 } & Alfalfa & 1409 & 60 & & 1 & 69 & 4 & 5 & 14 & 1 & 1 & & 4 & 168 & 5 & 1 & & 2 & & 1 & 3 & 15 & 25 & 9 & 3 & 10 & 1810 \\
\hline & Almond & 11 & 2298 & 1 & 6 & 51 & & 35 & 64 & 5 & & 1 & & 99 & 48 & 29 & 3 & 1 & & & & 10 & & 81 & 7 & 24 & 2774 \\
\hline & Apples & & 3 & 2 & & 4 & & & 4 & & & & & 1 & 2 & & & & & & & & & 2 & & & 18 \\
\hline & Christmas Trees & & 8 & & 10 & 4 & & 1 & 3 & & & & & 5 & & 5 & 1 & & & & & & 1 & 6 & & 3 & 47 \\
\hline & Cotton & 27 & 53 & & 5 & 1170 & 7 & 28 & 11 & 4 & & & 3 & 55 & 4 & 7 & & & & & 5 & 16 & 66 & 17 & 15 & 10 & 1503 \\
\hline & Dry Beans & & 1 & & & & 9 & & 5 & & & & & & & & & & & & & & & & & 6 & 21 \\
\hline & Fallow/Idle cropland & 7 & 4 & & & 17 & 70 & 3 & 1 & & & & 2 & 7 & 1 & & & & & & & 6 & 2 & 1 & 4 & & 125 \\
\hline & Grapes & & 7 & & 1 & 6 & 1 & 14 & 63 & 1 & & & 1 & 4 & & 3 & & 1 & & & & 2 & 1 & 2 & & 1 & 108 \\
\hline & Olives & 1 & 36 & & & 4 & & 6 & 158 & 34 & & & & 16 & 28 & 14 & & & & & & 1 & & 16 & & 5 & 319 \\
\hline & Onions & & 1 & & & 1 & & & & 1 & & & & & & & & & & & & & & & & & 3 \\
\hline & Oranges & & & & & & & & & & & 3 & & & & & & & & & & & & 1 & & & 4 \\
\hline & Other Hay/ Non Alfalfa & & & & 1 & & & & & & & 1 & & 1 & & & & & & & & & & & & & 3 \\
\hline & \begin{tabular}{|l|} 
Pasture/Grass \\
\end{tabular} & 73 & 148 & & 3 & 47 & 2 & 13 & 41 & 3 & & & 2 & 840 & 11 & 5 & 1 & 1 & & & 24 & 10 & 8 & 20 & 2 & 15 & 1269 \\
\hline & Peaches & & 70 & & 2 & 5 & & 4 & 18 & & & & & 12 & 193 & 3 & & 1 & & & & & & 40 & & 3 & 351 \\
\hline & Pistachios & & & & & & & & & & & & & & 1 & & & & & & & & & & & & 1 \\
\hline & Plums & & & & & 1 & & & & & & & & & & & 1 & & & & & & 2 & & & & 4 \\
\hline & \begin{tabular}{|l|} 
Prunes \\
\end{tabular} & & 29 & & 3 & 2 & & & & 1 & & & & 1 & & 14 & & 24 & & & & & & 2 & & 1 & 77 \\
\hline & Sod/Grass Seed & & 10 & & 1 & 1 & & & & & & & & 1 & 5 & 3 & 8 & 3 & & & & & & 4 & & & 36 \\
\hline & Sudan & & 12 & & 1 & 1 & & 1 & & & & & & & & 3 & 2 & 14 & & & & & & & & & 34 \\
\hline & Sugarbeets & 2 & 1 & & & 21 & 1 & & 1 & & & & & 2 & & & & & & & 48 & 8 & 2 & & 1 & & 87 \\
\hline & \begin{tabular}{|l|} 
Corn \\
\end{tabular} & 20 & 27 & & & 61 & 8 & 3 & 7 & & & & 4 & 18 & 1 & & & & & 2 & & 218 & 26 & 4 & 4 & 5 & 408 \\
\hline & Tomatoes & 8 & 14 & & & 81 & 9 & 3 & 14 & & 3 & & 7 & 11 & 2 & 5 & & & & & 1 & 17 & 311 & 9 & 29 & 13 & 537 \\
\hline & Walnuts & 1 & 113 & & 2 & 10 & & 12 & 11 & & & 2 & & 20 & 36 & 6 & & & & & & & & 93 & 1 & 3 & 310 \\
\hline & Watermelons & 1 & 8 & & & 6 & 9 & & & & & & & 10 & 1 & & & & & & & 2 & 18 & 2 & 53 & & 110 \\
\hline & Grand Total & 1560 & 2903 & 3 & 36 & 1562 & 120 & 128 & 415 & 50 & 4 & 7 & 23 & 1271 & 338 & 98 & 16 & 47 & 0 & 3 & 81 & 305 & 462 & 309 & 119 & 99 & 9959 \\
\hline
\end{tabular}


2011 Confusion Matrix - Utilizing 90\% of DWR ground survey data from 2001 plus 10\% 2011 DWR ground survey added to the Training Data set (EToF omitted)

\begin{tabular}{|c|c|c|c|c|c|c|c|c|c|c|c|c|c|c|c|c|c|c|c|c|c|c|c|c|c|c|c|}
\hline & & & \multicolumn{25}{|c|}{ User Classification } \\
\hline & Crop Type & $\begin{array}{l}\frac{\pi}{\pi} \\
\frac{\pi}{4} \\
\end{array}$ & 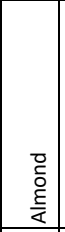 & $\frac{\tilde{\omega}}{\frac{0}{2}}$ & 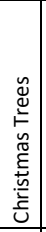 & $\begin{array}{l}5 \\
0 \\
\pm 0 \\
0\end{array}$ & $\begin{array}{l}n \\
\check{c} \\
\mathbb{N} \\
\infty \\
\geq \\
\vdots\end{array}$ & 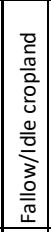 & $\begin{array}{l}\tilde{\Xi} \\
\frac{0}{0} \\
\frac{0}{0}\end{array}$ & 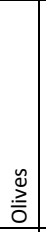 & 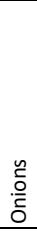 & 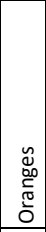 & 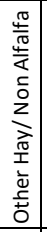 & 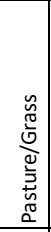 & 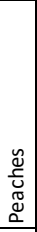 & 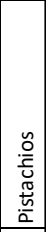 & $\frac{\text { E⿱丶万丂 }}{a}$ & 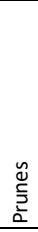 & 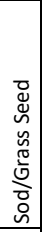 & $\begin{array}{l}\frac{c}{\pi} \\
\frac{\pi}{0} \\
\bar{n} \\
\end{array}$ & 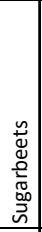 & 5 & 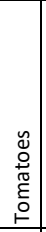 & $\begin{array}{l}\text { 芩 } \\
\frac{5}{\pi} \\
3\end{array}$ & 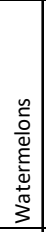 & 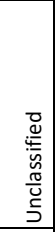 & $\begin{array}{l}\bar{\pi} \\
\stackrel{0}{0} \\
\circ \\
0 \\
\frac{0}{0} \\
0 \\
0\end{array}$ \\
\hline \multirow{25}{*}{ 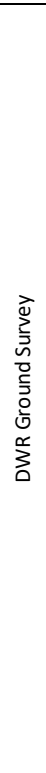 } & Alfalfa & 411 & 15 & 1 & 1 & & & 5 & 22 & & & & & 25 & 2 & 3 & & & 1 & & & 11 & & & & & 497 \\
\hline & Almond & 3 & 1721 & 7 & 12 & 17 & & 16 & 122 & 3 & 4 & 22 & 6 & 12 & 5 & 98 & 2 & 6 & & 1 & 1 & & & 4 & & 17 & 2079 \\
\hline & Apples & 3 & 21 & 7 & & 3 & & 9 & 7 & & 1 & 1 & 2 & 1 & & 4 & 1 & 1 & & & & & & 2 & & 3 & 66 \\
\hline & Christmas Trees & 1 & 3 & & 2 & 2 & & & 8 & & 1 & & & & & 2 & & 1 & & & & & & & & 4 & 24 \\
\hline & Cotton & 3 & 25 & 3 & 4 & 125 & & 10 & 31 & & 3 & & 3 & 3 & 2 & 13 & & 1 & & 1 & & 5 & & 1 & & 2 & 235 \\
\hline & Dry Beans & & 4 & & & 14 & & 4 & & & & & & & & & & & & & & 1 & 1 & & & & 24 \\
\hline & Fallow/Idle cropland & 2 & 13 & 7 & & 20 & & 53 & 10 & 1 & 3 & & 1 & 15 & 5 & 9 & & & & & & 3 & & 11 & & 1 & 154 \\
\hline & Grapes & 10 & 156 & 18 & 10 & 6 & & 12 & 1339 & 2 & 1 & 17 & 1 & 18 & 16 & 34 & 5 & & & & & 1 & 1 & 7 & 1 & 28 & 1683 \\
\hline & Olives & & 7 & 5 & 2 & 1 & & 3 & 8 & 3 & & 2 & 1 & & & 14 & & 1 & & & & & & & & 2 & 49 \\
\hline & Onions & & 1 & & & & & 1 & 1 & & 1 & & & & & & & & & & & & & & & & 4 \\
\hline & Oranges & & 28 & 2 & 1 & & & 1 & 13 & 1 & & 81 & 1 & & 3 & 17 & & & & & & & & 1 & & 3 & 152 \\
\hline & Other Hay/ Non Alfalfa & 19 & 45 & 1 & & 1 & & 10 & 28 & 1 & & 2 & & 82 & 1 & 7 & & & 3 & & & & & 2 & & 17 & 219 \\
\hline & Pasture/Grass & & 14 & 1 & & & & & 7 & & & & & 20 & & & 3 & 1 & & & & & & 1 & & 2 & 49 \\
\hline & Peaches & & 1 & & & & & & & & & & & & & & & & & & & & & & & & 1 \\
\hline & Pistachios & 2 & 49 & 5 & 4 & 8 & & 21 & 28 & & 4 & 29 & 1 & 1 & 5 & 248 & 1 & 1 & & & & 2 & 1 & 1 & & 9 & 420 \\
\hline & Plums & & 6 & 1 & & 1 & & & 1 & & & & & & 2 & & 7 & 2 & & & & & & & & & 20 \\
\hline & Prunes & & 7 & & & 1 & & & 1 & & & & & 1 & & 1 & 4 & 5 & & & & & & & & & 20 \\
\hline & Sod/Grass Seed & & & & & & & & & & & & & & & & & & & & & & & & & & 0 \\
\hline & \begin{tabular}{|l|} 
Sudan \\
\end{tabular} & & & & & & & & & & & & & & & & & & & & & & & & & & 0 \\
\hline & Sugarbeets & & & & & & & & & & & & & & & & & & & & & & & & & & 0 \\
\hline & Corn & 2 & 2 & & & 4 & & & 11 & & 1 & & 1 & & 2 & & & & & & & 94 & 1 & 1 & & 10 & 129 \\
\hline & Tomatoes & 1 & & & & & 1 & & 2 & & & & & & & & & & & & & 12 & 34 & & & 2 & 52 \\
\hline & Walnuts & 3 & 12 & & & 1 & & 1 & 7 & & 1 & & & 1 & 7 & 2 & 1 & & & & & & & 11 & & 1 & 48 \\
\hline & Watermelons & & 1 & & & & & & 7 & & 1 & & & & & & & & & & & & & & & 1 & 10 \\
\hline & Grand Total & 460 & 2131 & 58 & 36 & 204 & 1 & 146 & 1653 & 11 & 21 & 154 & 17 & 179 & 50 & 452 & 24 & 19 & 4 & 2 & 1 & 129 & 38 & 42 & 1 & 102 & 5935 \\
\hline
\end{tabular}

